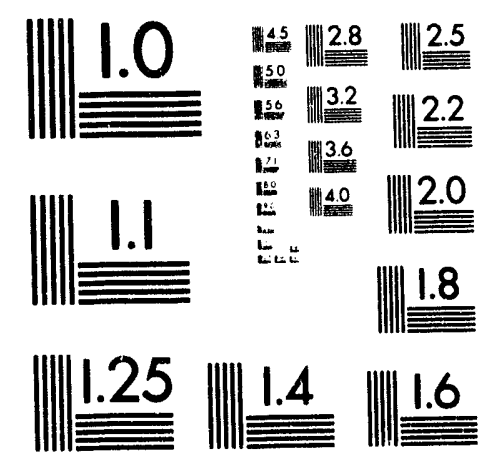



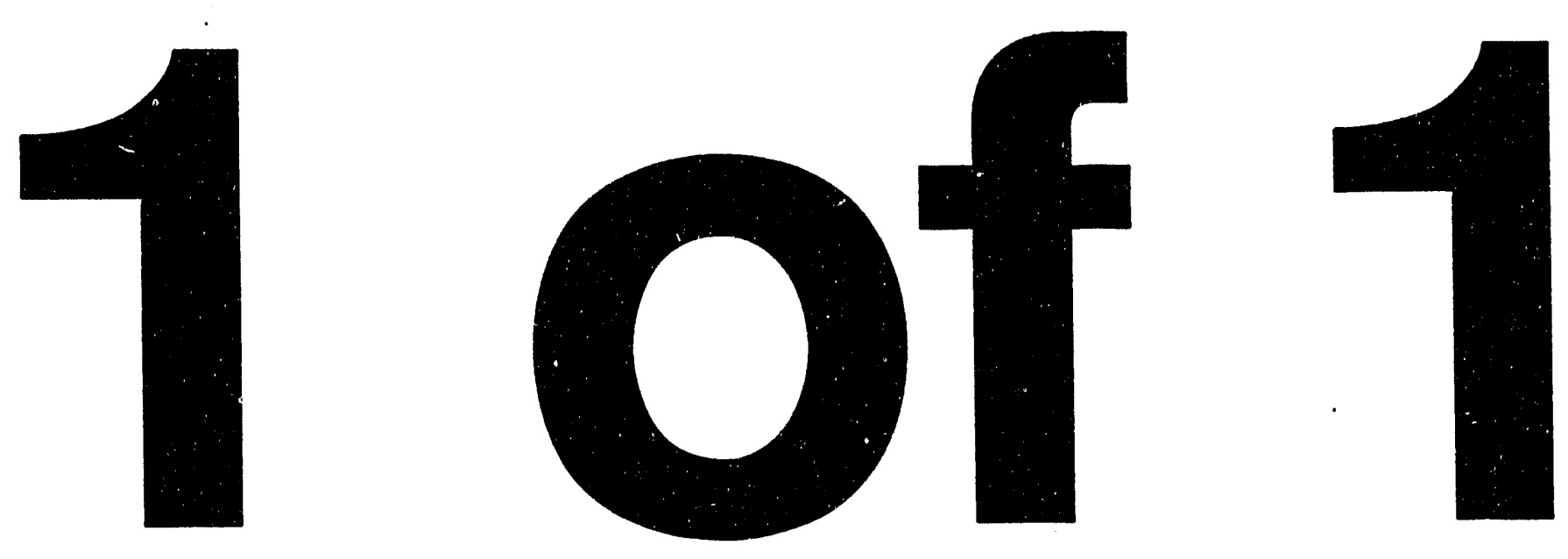


\section{COAL SECTOR PROFILE}

June 5, 1990

\section{MASTER}




\section{TABLE OF CONTENTS}

$\underline{\text { Page }}$

EXECLTIVE SUMMARY

I. PRODUCTION END-USE MARKET SHARE

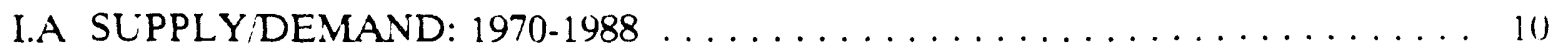

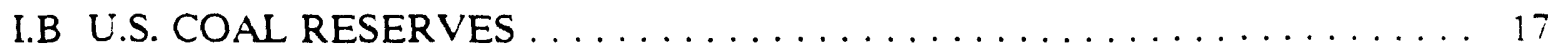

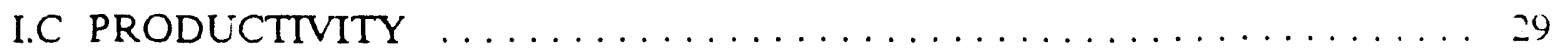

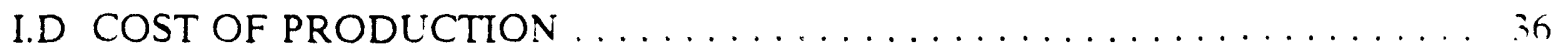

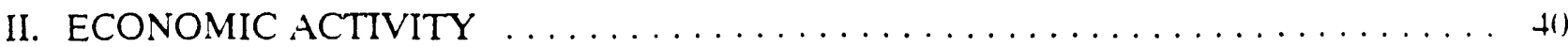

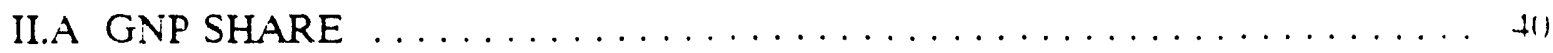

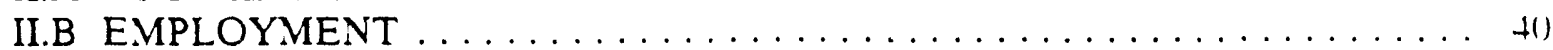

II.C TRADE: IMPORTSIEXPORTS $\ldots \ldots \ldots \ldots \ldots \ldots \ldots \ldots \ldots \ldots \ldots$

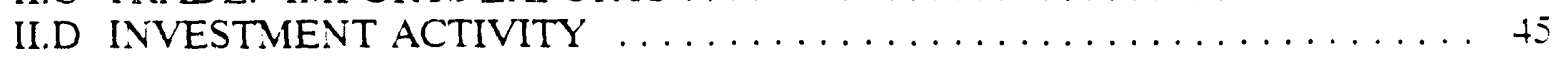

III. SECTOR STRUCTURE $\ldots \ldots \ldots \ldots \ldots \ldots \ldots \ldots \ldots \ldots \ldots \ldots \ldots$

III.A INDUSTRY PROFILE $\ldots \ldots \ldots \ldots \ldots \ldots \ldots \ldots \ldots \ldots \ldots \ldots \ldots \ldots$

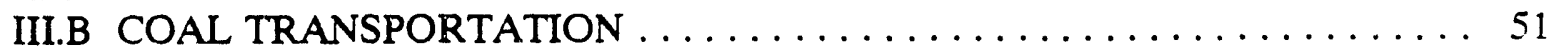

III.C PERIPHERAL INDUSTRIES $\ldots \ldots \ldots \ldots \ldots \ldots \ldots \ldots \ldots \ldots \ldots \ldots$

IV. FUEL CYCLE CHARACTERIZATION AND COSTS $\ldots \ldots \ldots \ldots \ldots \ldots \ldots$

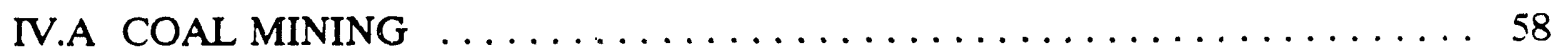

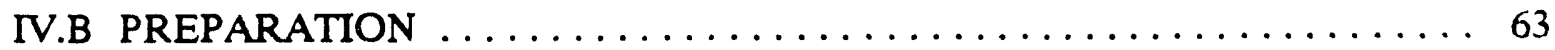

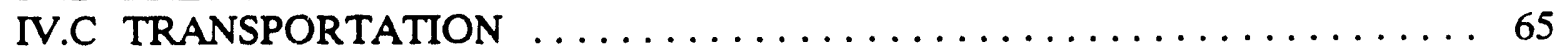

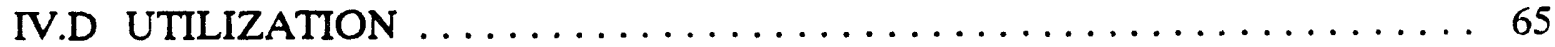

IV.E EMISSIONS AND DISPOSAL OF RESIDUALS $\ldots \ldots \ldots \ldots \ldots \ldots \ldots \ldots$

V. DEVELOPING TECHNOLOGIES $\ldots \ldots \ldots \ldots \ldots \ldots \ldots \ldots$

V.A MINING TECHNOLOGY $\ldots \ldots \ldots \ldots \ldots \ldots \ldots \ldots \ldots \ldots \ldots \ldots$

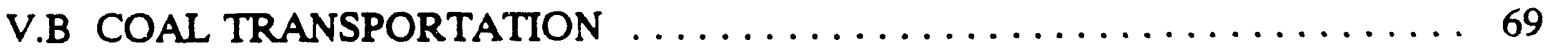

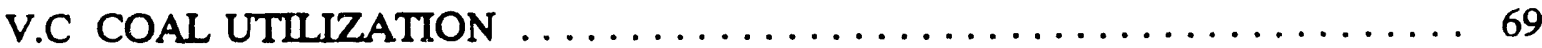

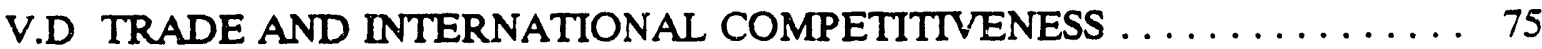

VI. REGULATORY REGIME: LEGISLATION AND TAXES $\ldots \ldots \ldots \ldots \ldots \ldots \ldots$

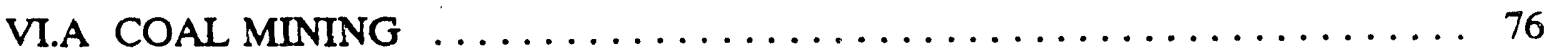

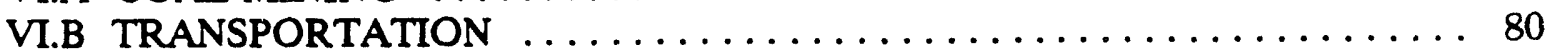

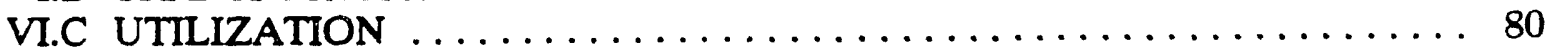




\section{COAL SECTOR PROFILE EXECUTIVE SUMMARY}

\section{BACKGROLND}

Coal has several intrinsic strengths. It is our largest domestic energy resource with recoverable reserves estimated at 268 billion short tons or 5.896 quads Btu equivalent. This is approximately 95 percent of U.S. fossil energy resources (Table 1). It is relatively inexpensive to mine. and on a per Btu basis it is generally much less costly to produce than other energy sources. Its chief drawbacks are the environmental, health. and safety concerns that must be addressed in its production and consumption.

Historically, coal has played a major role in U.S. energy markets. Coal fueled the railroads. heated the homes. powered the factories. and provided the raw materials for steel-making. In 1920. coal supplied over three times the amount of energy of oil. gas. and hydro combined (Figure 1). From 1920 until the mid 1970s. coal production remained fairly constant at 400 to 600 million short tons a year. Rapid increases in overall energy demands. which began during and atter World War II. were mostly met by oil and gas.

By the mid 1940s, coal represented only half of total energy c nsumption in the U.S. In fact, post-war coal production, which had risen in support of the war effort and the postwar Marshall plan, decreased approximately 25 percent between 1945 and 1960 . Coal demand in the post-war era up until the 1970 s was characterized by increasing coal use by the electric utilities but decreasing coal use in many other markets (e.g., rail transportation).

The oil price shocks of the 1970 s, combined with natural gas shortages and problems with nuclear power, returned coal to a position of prominence. The greatly c.panded use of coal was seen as a key building block in U.S. energy strategies of the 1970s.

Coal continues to play a major role in the U.S. energy markets. Coal production increased from 613 million short tons per year in 1970 to 950 million short tons in 1988, up over 50 percent. Production and use of coal in the U.S. now stand at all-time high levels. This has enabled coal to maintain its market share of approximately 20 to 25 percent of total U.S. energy consumption, a position it has held since the early 1960 s (Figure 2).

\section{MINING TECHNOLOGY}

Coal is mined by either underground or surface methods. Most underground mines in the U.S. are room and pillar mines that extract coal using conventional or continuous miner machinery. The remainder of underground mines are primarily longwall mines, a high-productivity mining approach that has rapidly been growing in the industry.

Surface mines are primarily open-pit or strip mines. Open-pit operations use power shovels and trucks to remove overburden and mine the coal. Strip mines use large excavating machines called draglines. 

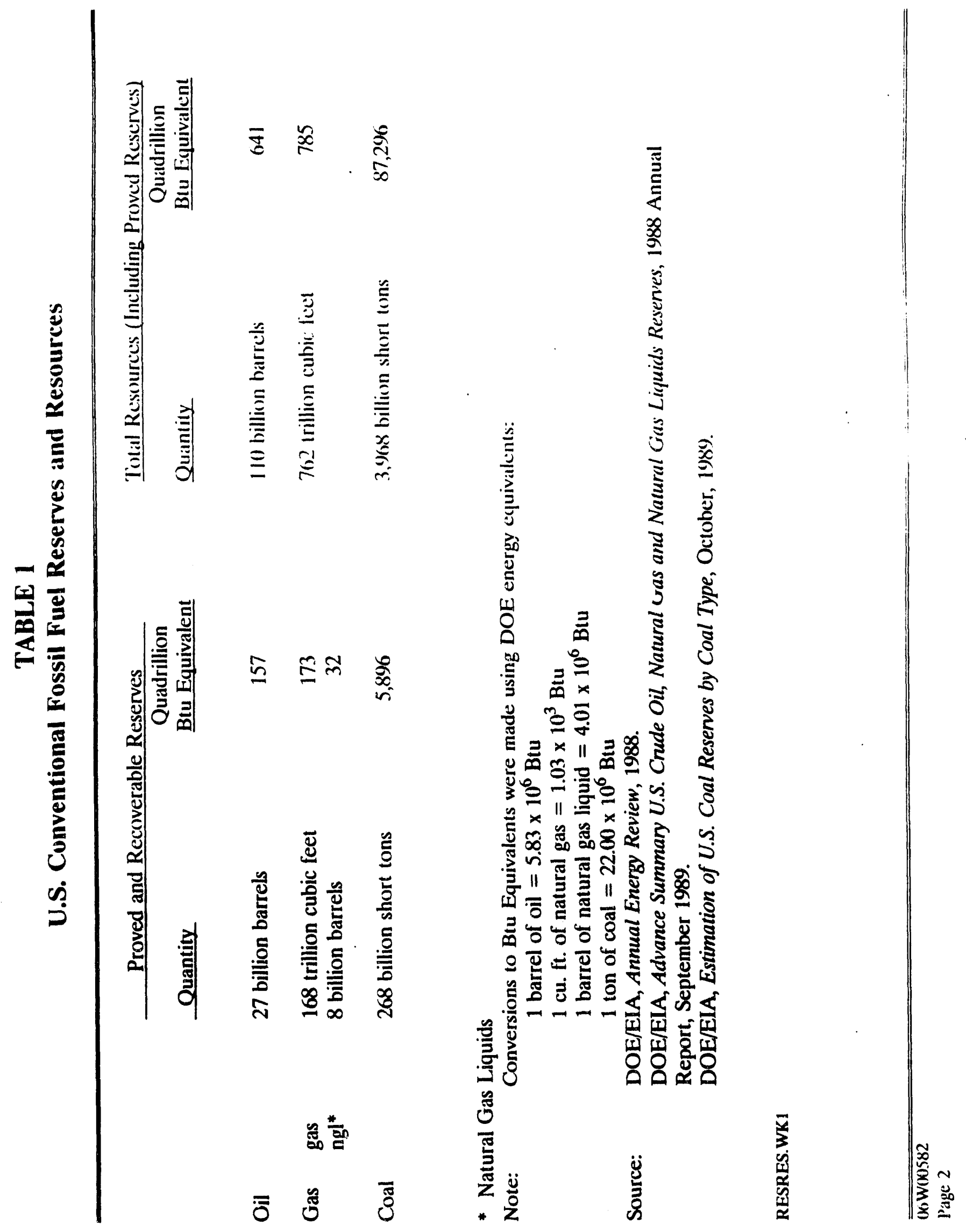


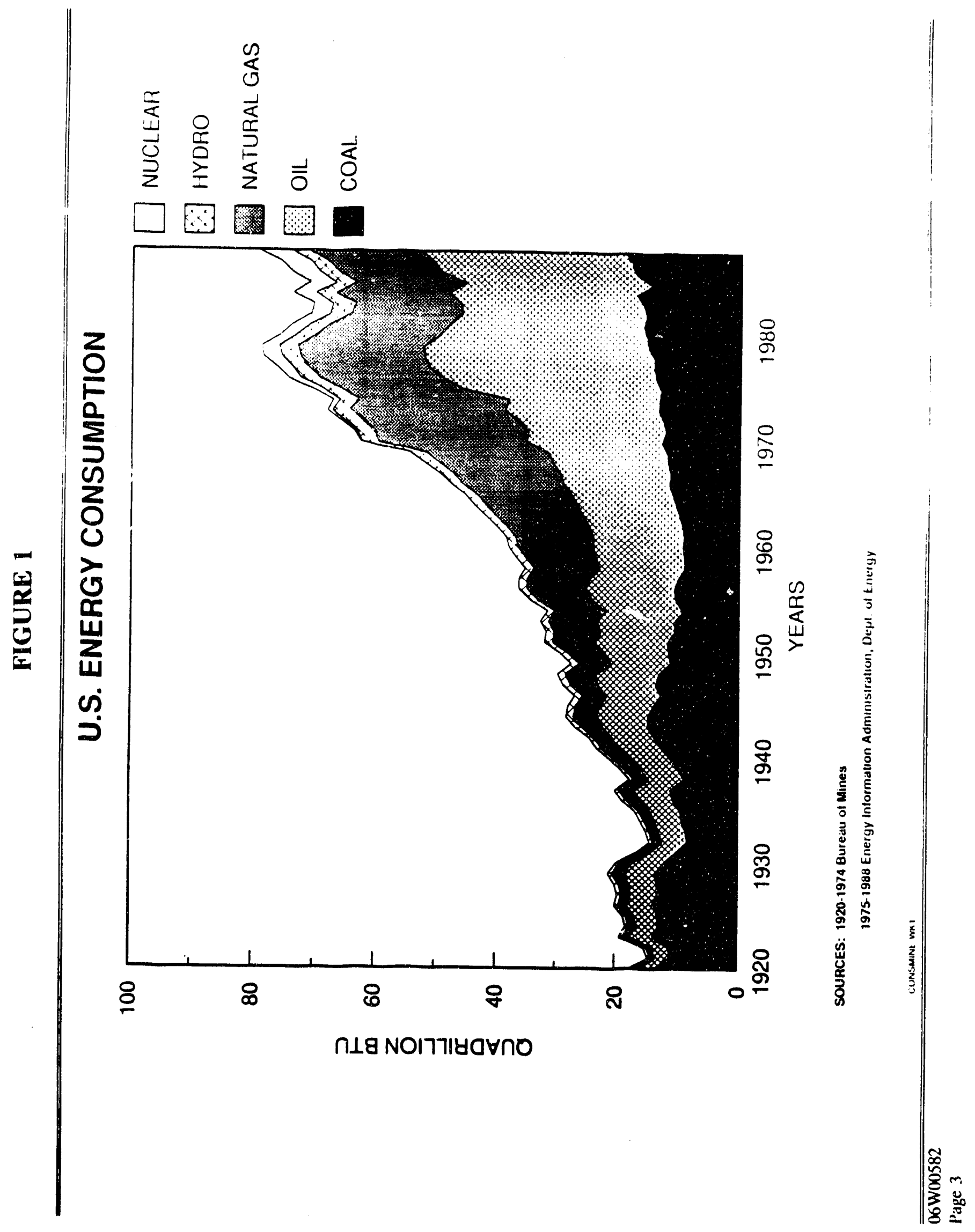




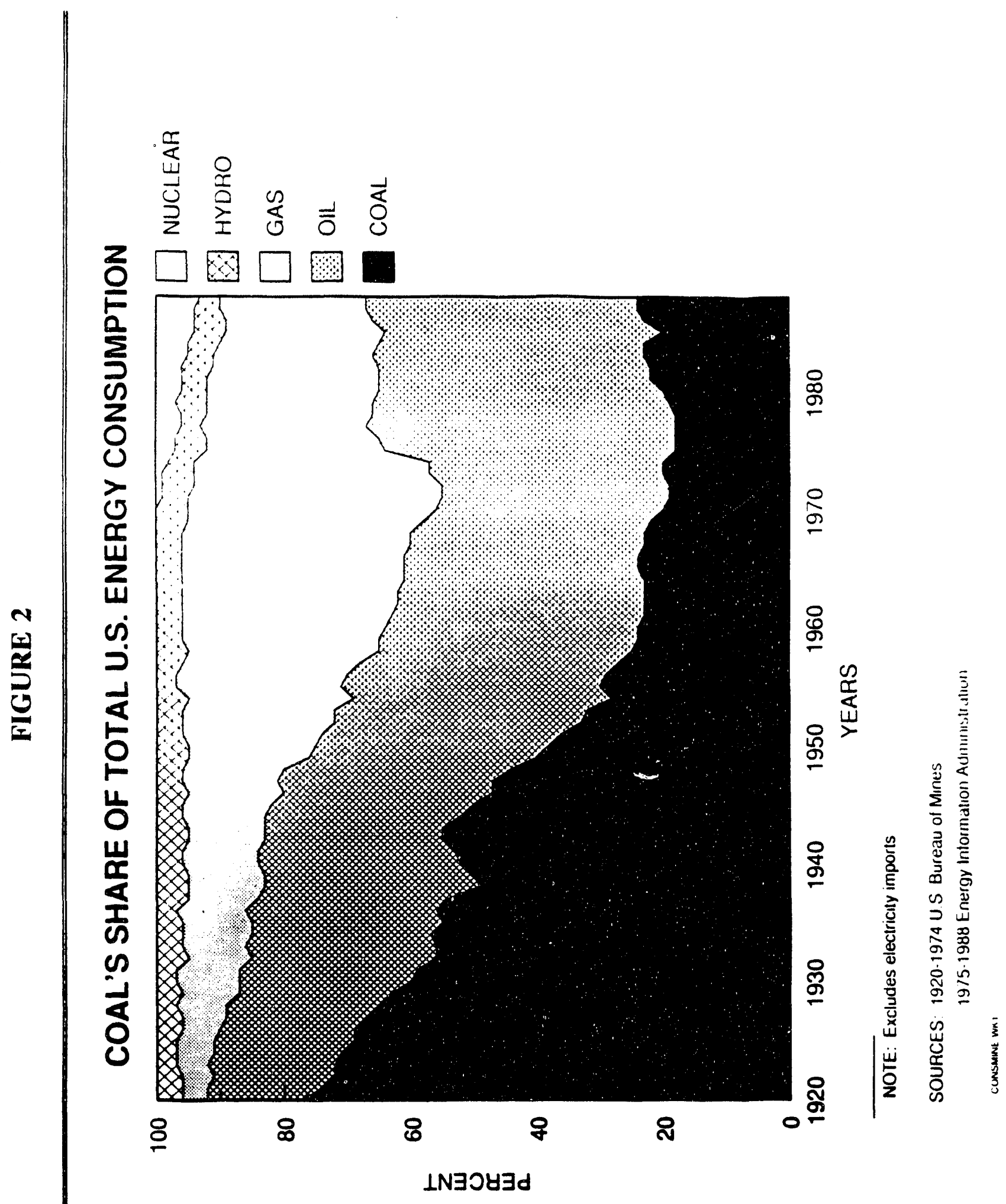


Mining techniques have improved considerably over time. Mechanization has increased the efficiency and productivity of coal mining, thereby helping coal to remain cost-competitive.

Productivity, measured as the number of tons a miner produces per day, rose moderately during the first half of the century. Dramatic increases in productivity were made during the 1950 s and 1960s as continuous mining systems were introduced, roof-bolting improvements allowed for the sater development of larger scale underground mines. and production increased from surface mines. which in general are more productive and less labor intensive. During the 1970s, coal mine productivity declined as a result of labor unrest and various laws and regulations enacted due to health. salety, and environmental concerns: this led to increases in the cost and price of coal (Figure 3). Since the late 1970 s. productivity has increased dramatically as the result of the coal industry's success at incorporating the various new laws and regulations into their mining practices, and of increased competition leading to increased efficiency of their operations. Correspondingly. mincmouth prices have declined in recent years. Additional technological improvements. as well as increased mechanization and labor productivity, should help to maintain or improve coal's competitiveness in the energy markets of the future.

\section{TRANSPORTATION}

Historically. most coal has been transported by railroads. Today, railroads remain the toundation of the coal distribution system. In 1988, railroads originated 58 percent of coal delivered domestically, and an even higher percentage of exported coal. Most of the remaining shipments were about evenly divided between inland water shipments (on rivers and the Great Lakes), trucks, and tramways and conveyors.

Several developments in the last 10 to 15 years have lowered transportation rates for many coal users. These include the development of unit trains, measures taken by railroads to increase productivity, and increased competition in some transportation markets. Emerging transportation technologies are creating lighter, larger-volume cars and more efficient movements between suppliers and customers.

An area of ongoing tension in coal transportation stems from the Staggers Act of 1980 . This act, which partially deregulated rail rates, has broad support from the railroads. Conversely, some shippers, including some coal producers and consumers, argue that the Act has gone too far in allowing the carriers to set unreasonably high rates.

\section{UTILIZATION}

Coal is mostly used in the generation of electricity, although industrial plants, coke ovens, and export destinations also consume large quantities. In 1988, 77 percent of coal production was consumed by electric utilities, 8 percent by industrial plants, 4 percent went into coke production, and 10 percent was exported. The remaining 1 percent went into residential and commercial markets.

Coal is consumed in two primary ways: to create steam for generating electricity and industrial processes, and in the steel making process.

Most "steam coal" is consumed by electric utilities. Conversely, coal is the primary fuel used by electric utilities. In 1988, coal-fired powerplants generated 57 percent of the total U.S. electricity (Table 2). Conventional technology for generating electricity consists of a furnace where the coal 


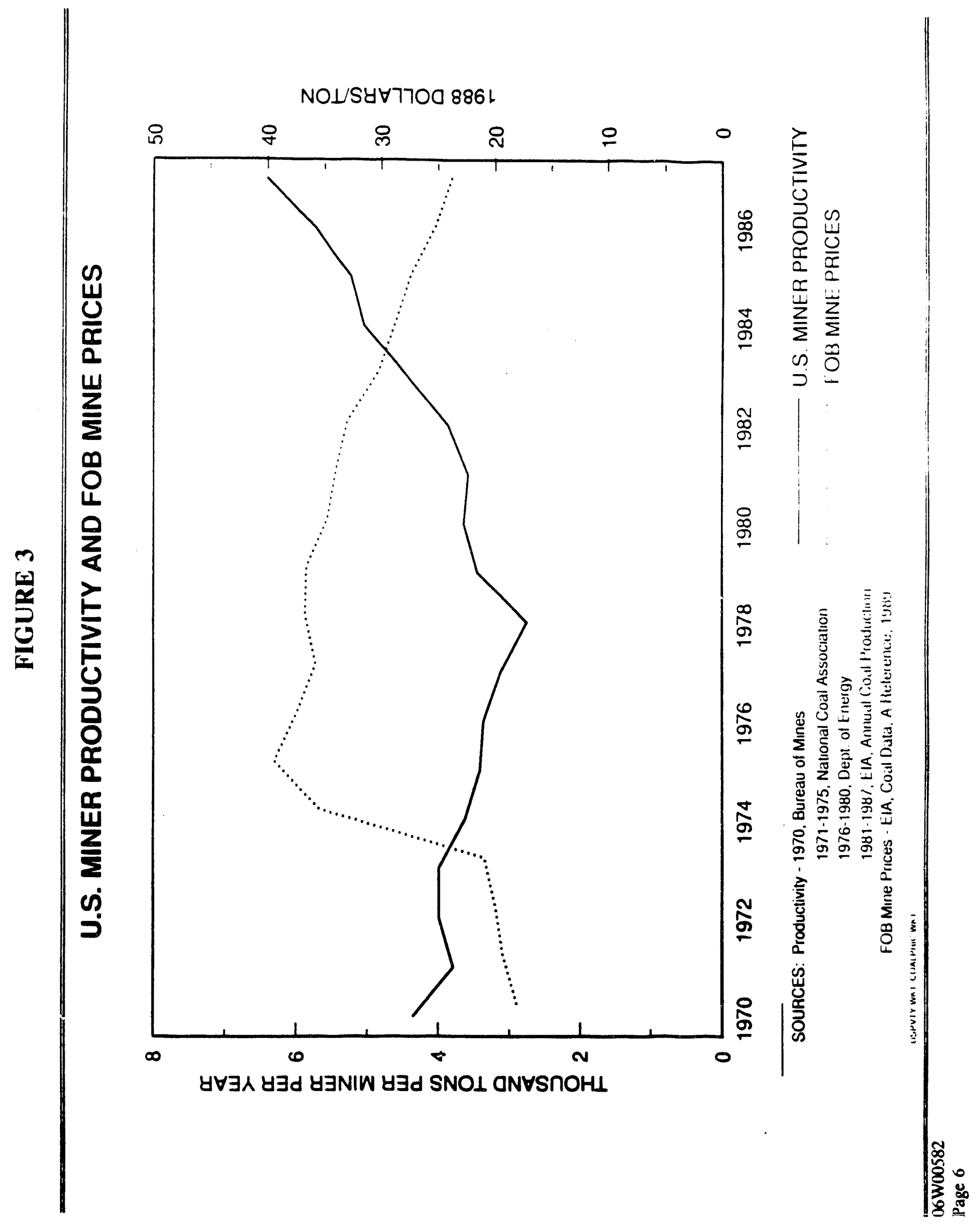




\section{TABLE 2}

\section{Estimated Electricity Generation by Fuel Type}

\begin{tabular}{lcc}
\hline & $\begin{array}{c}\text { Billion } \\
\text { Kilowatt Hours }\end{array}$ & Percent of Total \\
Coal & 1,541 & $57 \%$ \\
Natural Gas & 253 & $9 \%$ \\
Oil & 149 & $6 \%$ \\
Nuclear & 527 & $19 \%$ \\
Hydro/Other & 235 & $9 \%$ \\
TOTAL & 2.705 & $100 \%$
\end{tabular}

SOLRCE: EIA. Monthly Energy Review, November 1989. 
is combusted, a heat exchange process to turn water into steam, turbines to change the thermal energy into mechanical energy, and generators to create electricity. State-of-the-art clean coal technology currently being developed provides both improved efficiency (fewer Btu needed to generate a kilowatt-hour) and lower emissions of air pollutants. Additionally, steam coal is used as a source of steam and heat for many industrial processes.

Coal used in steel making is commonly called "metallurgical coal". This coal has unique qualities in that when heated in coke ovens in the absence of oxygen, it softens and fuses together forming coke, a vital ingredient in blast furnace iron-extracting technologies. In the blast furnace. the coke provides a source of heat and physical support for the iron ore and limestone. The iron produced is then refined to create steel.

\section{REGLLATORY REGIME}

Concurrent with the rise in coal production in the 1970s was the passage of several new laws and regulations involving mine health and safety issues. The Federal Coal Mine Health and Safery Acts of 1969 and 1977 improved safety standards in coal mining. The Federal Black Lung Benetits Act of 1977 and its amendments provided disability compensation for miners afflicted with black lung. a progressive respiratory disease resulting from the inhalation of coal dust.

Laws were also passed during the 1970s to mitigate the land and water environmental impacts of coal mining and use. The Surface Mining Control and Reclamation Act of 1977 required surface mines to adhere to specific mining standards and underground mines to take measures to control land subsidence. The Resource Conservation and Recovery Act of $1976 \mathrm{reg}$ 'lated the disposal of solid wastes at both the mine site and at coal-fired power plants. The Federal Water Pollution Control Act of 1972, later incorporated into the Clean Water Act of 1977 and its amendments, contained guidelines for maintaining water quality control, especially as it pertained to acid water drainage problems during coal mining and preparation.

Air pollution concerns regarding the burning of coal were addressed in the Clean Air Act of 1970 and its amendments which led to the establishment of New Source Performance Standards. These standards included allowable emission levels for sulfur dioxide, nitrogen oxides, and particulates. Electric utilities and other industrial coal-fired boilers built before 1971 are subject to emission controls set by the States and approved by the Environmental Protection Agency. Those constructed after 1971 must meet the Federal New Source Performance Standards. These standards were tightened in 1978 for electric utilities and for industrial boilers built after 1986.

These laws and regulations have helped make coal much safer and cleaner to mine and use. In 1987, there were 63 mining fatalities, the lowest number in this century. Accidents, measured on the basis of either per-hour worked or per-ton of coal mined, have steadily decreased since the enactment of the Federal Coal Mine Health and Safety Act of 1969. Compliance with the Surface Mining Control and Reclamation Act of 1977, the Resource Conservation and Recovery Act of 1976 and the Clean Water Act of 1977 (and its predecessor, the Federal Water Pollution Control Act of 1972) has greatly reduced acid mine drainage. Since the passage of the Clean Air Act, total emissions of sulfur dioxide from coal conbustion have declined. Since 1973, the peak year of $\mathrm{SO}_{2}$ emission, emissions from coal-fired power plants declined by over 10 percent despite a 75 percent increase in coal consumption. Particulates have decreased to one-sixth earlier levels (1970-1987). Nitrogen oxides have decreased about 8 percent on a pounds per Btu basis (1970-1987), but have risen overall with the growth in coal consumption (Table 3). 
TABLE 3

Atmospheric Emissions from Electric Utility Coal Combustion

\begin{tabular}{cc} 
Sector/Year & $\frac{\text { Consumption }}{\text { (quadrillion Btu) }}$ \\
\hline 1970 & 7.23 \\
1973 & 8.66 \\
1975 & 8.79 \\
1978 & 10.24 \\
1980 & 12.12 \\
1985 & 14.54 \\
1987 & 15.17
\end{tabular}

$\frac{}{\text { Annual Emissions ( } 10^{6} \text { tons) }}$

$\begin{array}{llll}16.0 & 3.3 & 2.4 & 181\end{array}$

$\begin{array}{llll}17.4 & 3.8 & 1.9 & 217\end{array}$

$\begin{array}{llll}16.9 & 4.0 & 1.6 & 220\end{array}$

$\begin{array}{llll}16.0 & 4.5 & 1.2 & 256 \\ 16.2 & 5.2 & 0.8 & 303\end{array}$

$\begin{array}{llll}15.4 & 6.2 & 0.4 & .364\end{array}$

$\begin{array}{llll}15.2 & 6.4 & 0.4 & 379\end{array}$

* Expressed as $10^{6}$ tons of carbon ernitted as $\mathrm{CO}_{2}$.

Source: DOE Office of Environmental Policy. 


\section{PRODUCTION/END-USE MARKET SHARE}

\section{I.A SUPPLY/DEMAND: $1970-1988$}

Historically, both coal production and consumption were concentrated in the eastern United States. As recently as $19^{\wedge} \mathrm{M} .93$ percent of U.S. coal production originated east of the Mississippi River and 88 percent of domestic deliveries were to customers located east of the Mississippi River.

By 1988 , both production and consumption patterns shifted significantly. In 1988, about 40 percent of prod'sction and domestic deliveries were west of the Mississippi River (Figure 4). This shift was due primarily to two tactors: economic growth in the southwestern U.S. and the demand for low-sulfur coal. In particular, the low-sulfur coals of the Powder River Basin (Wyoming and Montana) are inexpensive to mine and can be competitively priced even with long-distance transportation to consumers. Powder River Basin subbituminous coal is frequently shipped over 1.00() miles tc consumers around the U.S.. and is being used or tested at several powerplants east of the Mississippi River.

Some utilities have begun to burn some or all subbituminous Power River coal in their bituminous boilers. Depending on boiler design, these power plants have found that with either adjustments to their units or, if needed, by using a blend of subbituminous and higher Btu bituminous coal, subbituminous coals could be burned with little adverse effect on the boiler's efficiency.

\section{I.A.1 Supply}

Until the early 1970 s, nearly all coal was mined east of the Mississippi River, primarily in the Appalachian Mountains and Illinois Basin. However, by the mid-1970s, substantial increases in production occurred in western regions, especially the Powder River Basin. These increases were due primarily to the coal's favorable costs and availability as a fuel for electric utilities, many in the southwest, and to its generally low sulfur contents that could often meet $\mathrm{SO}_{2}$ emission limits with little ir no additional need for control equipment.

Since 1970, nearly all of the growth in U.S. coal production has been in regions west of the Mississippi River (Figure 5). From 1970 to 1988, eastern coal production went from 568 to 582 million tons, an increase of only about 2 percent. Western coal production, however, grew from 45 million tons in 1970 to 370 million tons in 1988, an over seven-fold increase. Western coal production's share of total U.S. production went from 7 percent in 1970 to 39 percent in 1988.

Coal was produced in 27 States in 1988, but nearly half of the tonnage was mined in Kentucky, Wyoming, and West Virginia (Figure 6). Almost 70 percent of the tonnage was bituminous-rank coal, with most of the balance being subbituminous coal and lignite. Production of anthracite, once a major source of U.S. energy supply, now accounts for less than one percent of U.S. coal production. Anthracite production comes exclusively from central Pennsylvania and has long been in decline because of competition from other fuels and difficult mining conditions that have kept the price of anthracite high. 


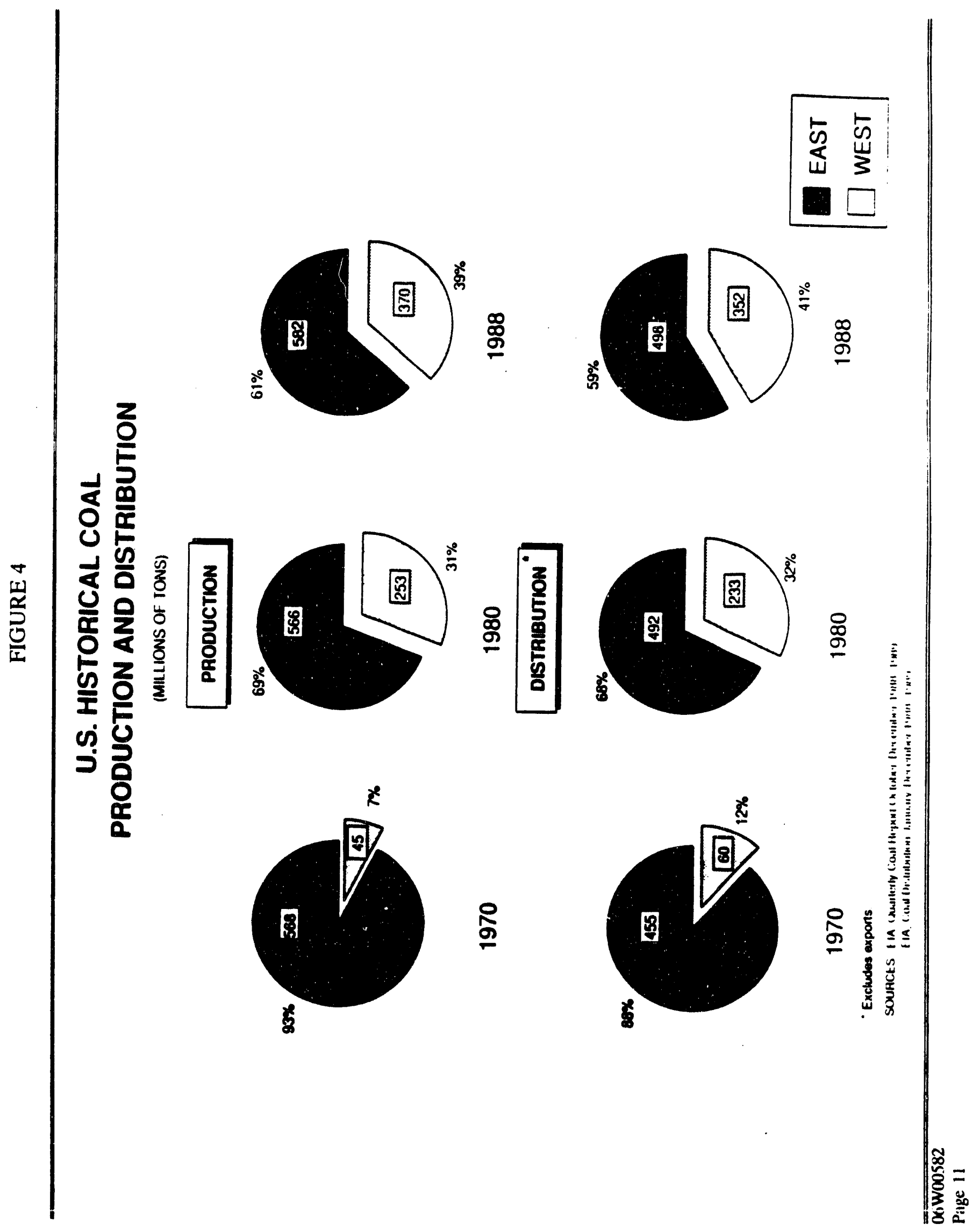




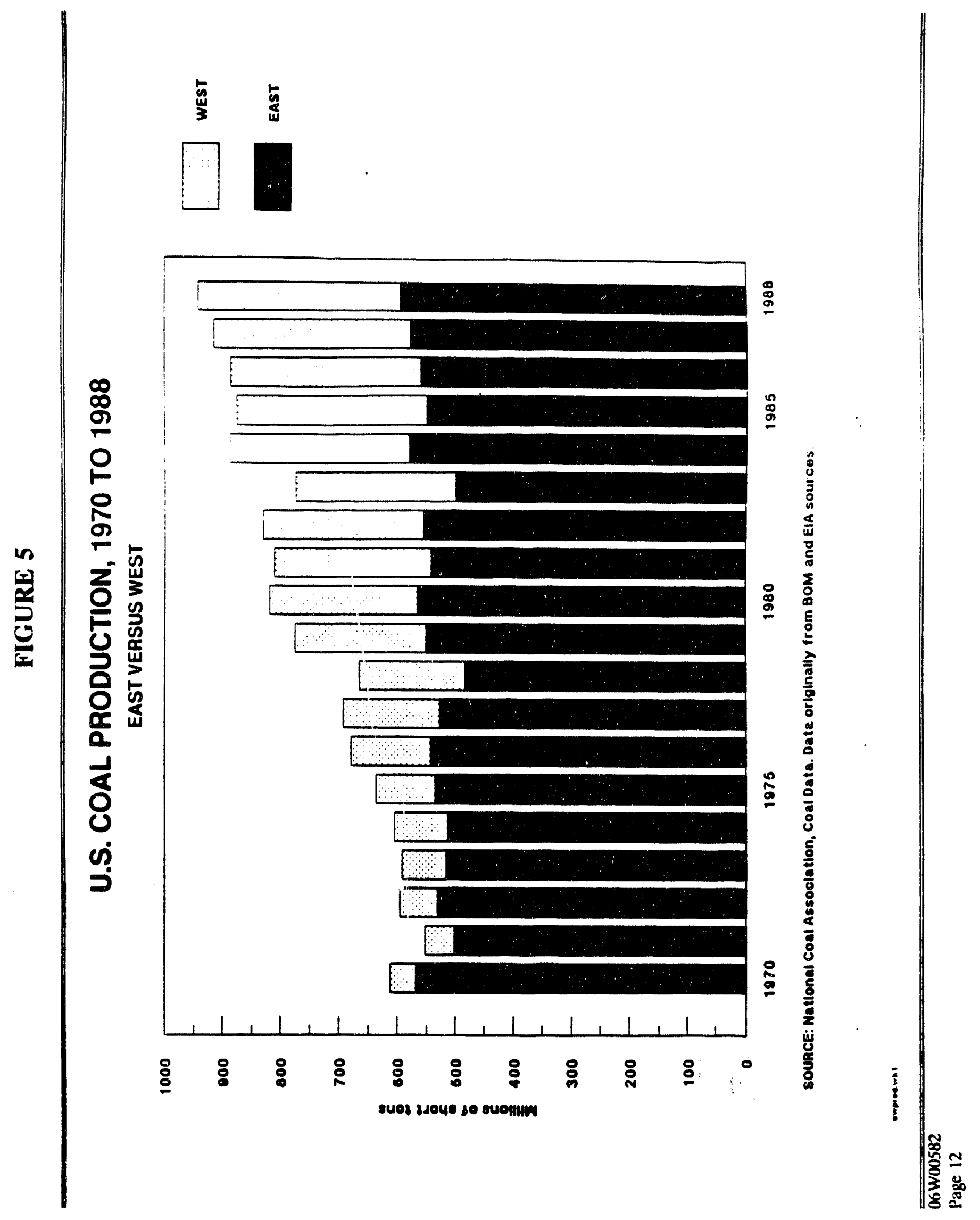




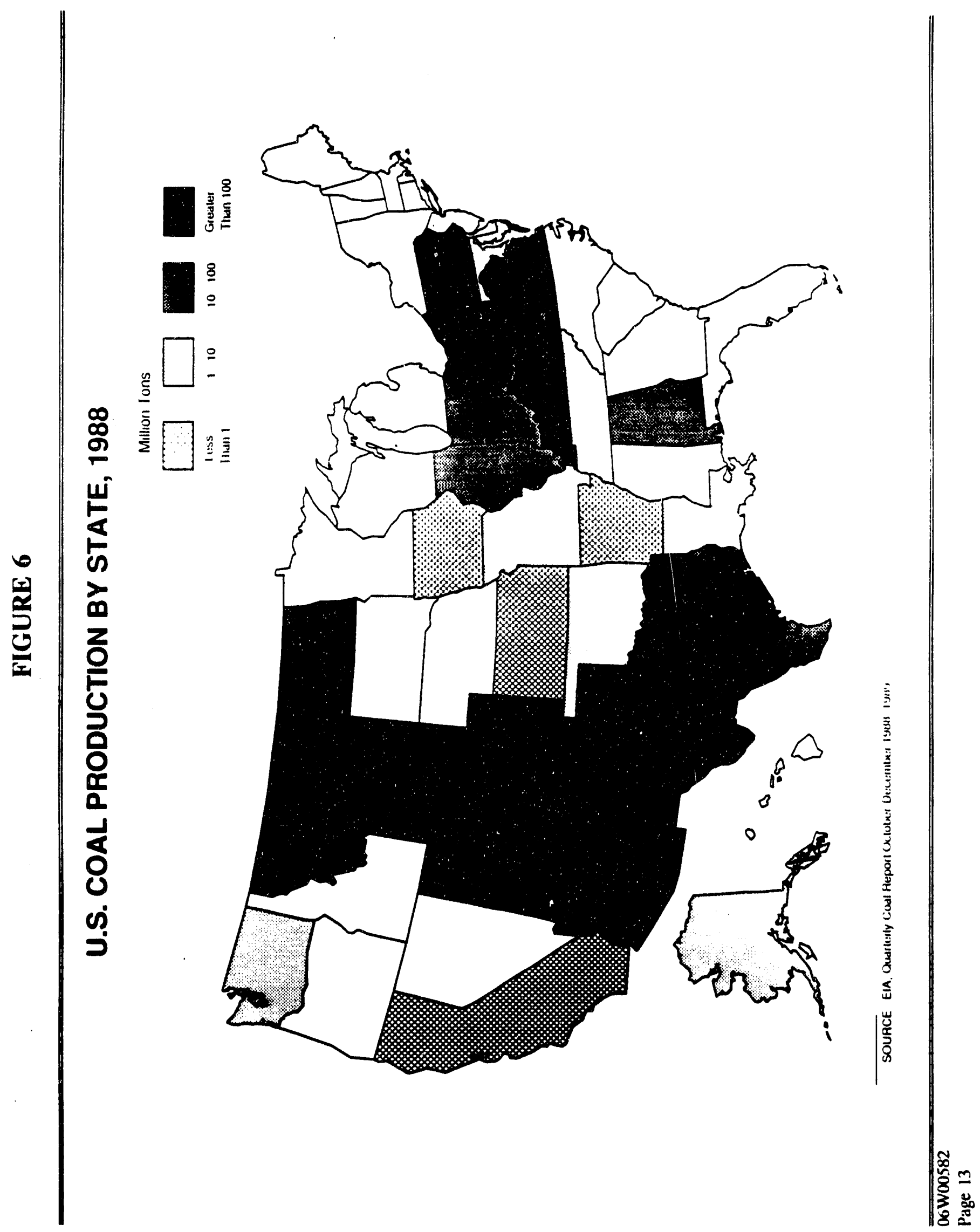


Between 1970 and 1988, U.S. coal production shifted not only from east to west but also from underground to surface methods (Figure 7). This growth was primarily due to the opening of western surface mines. In 1970, underground mines produced nearly 60 percent of the coal. almost all of it in the east. Less than 3 percent of underground production came from western mines. By 1988, 60 percent of U.S. coal production came from surface mines, and in turn almost 60 percent of all the surface production came from the west. These changes, both in regional production patterns and mining methods, have led to substantial shifts in national totals by mining methods, in labor productivity, and in workforce composition.

West of the Mississippi, surface mining accounts for over 90 percent of total production. The geology of many of the western coal fields is such that large-scale, highly productive surface mines are typical. In 19871 western surface mines producing more than 1 million tons per year accounted for 300 of the 3135 million tons of western surface coal mined, and over two-thirds of this production came from mines producing 5 million tons or more. By contrast, surface mines east of the Mississippi are smaller. and none produces as much as 5 million tons a year.

There are also significant differences in productivity between eastern and western surface mines. The average productivity for surface mines in 1988, measured as the average tons of coal mined per worker hour. was 2.99 tons per miner-hour for eastern mines, and 10.73 tons per minerhour for western mines. This is largely due to western surface mines having the thicker coal beds and better mining conditions. Western underground mines are also more productive, with an average productivity of 3.55 tons per miner-hour as compared to 2.32 tons per miner-hour in eastern underground mines.

\section{I.A.2 Demand}

From 1920 until the early 1970s (except during World War II), coal's share in meecing the energy needs of the U.S. declined steadily. In 1920, coal met 75 percent of the energy demand and in the 1940s it represented about 50 percent of the energy mix.

By 1970 , coal represented only 20 percent of total energy demand, the rest being met by oil, gas, and hydro and nuclear power. Domestic coal consumption, spurred by higher prices and occasional availability problems with oil and gas, rose from 523 million tons in 1970 to 882 million tons in 1988. Coal now represents almost 24 percent of total energy consumption.

U.S. electric utilities are, by far, the largest consumers of coal (Figure 8). In 1970, electric utilities purchases comprised nearly 54 percent of the coal produced. By 1988, their share had risen to 77 percent. Coal is used by utilities to produce high-pressure steam for driving electrical generators. Due largely to the cost advantages that coal offers over oil and gas and the problems in development of nuclear power, the amount of coal used by utilities has risen steadily, from 320 million tons in 1970 to 757 million tons in 1988.

1) The latest statistics available for production by these mine size categories are found in EIA's Coal Production 1987. 

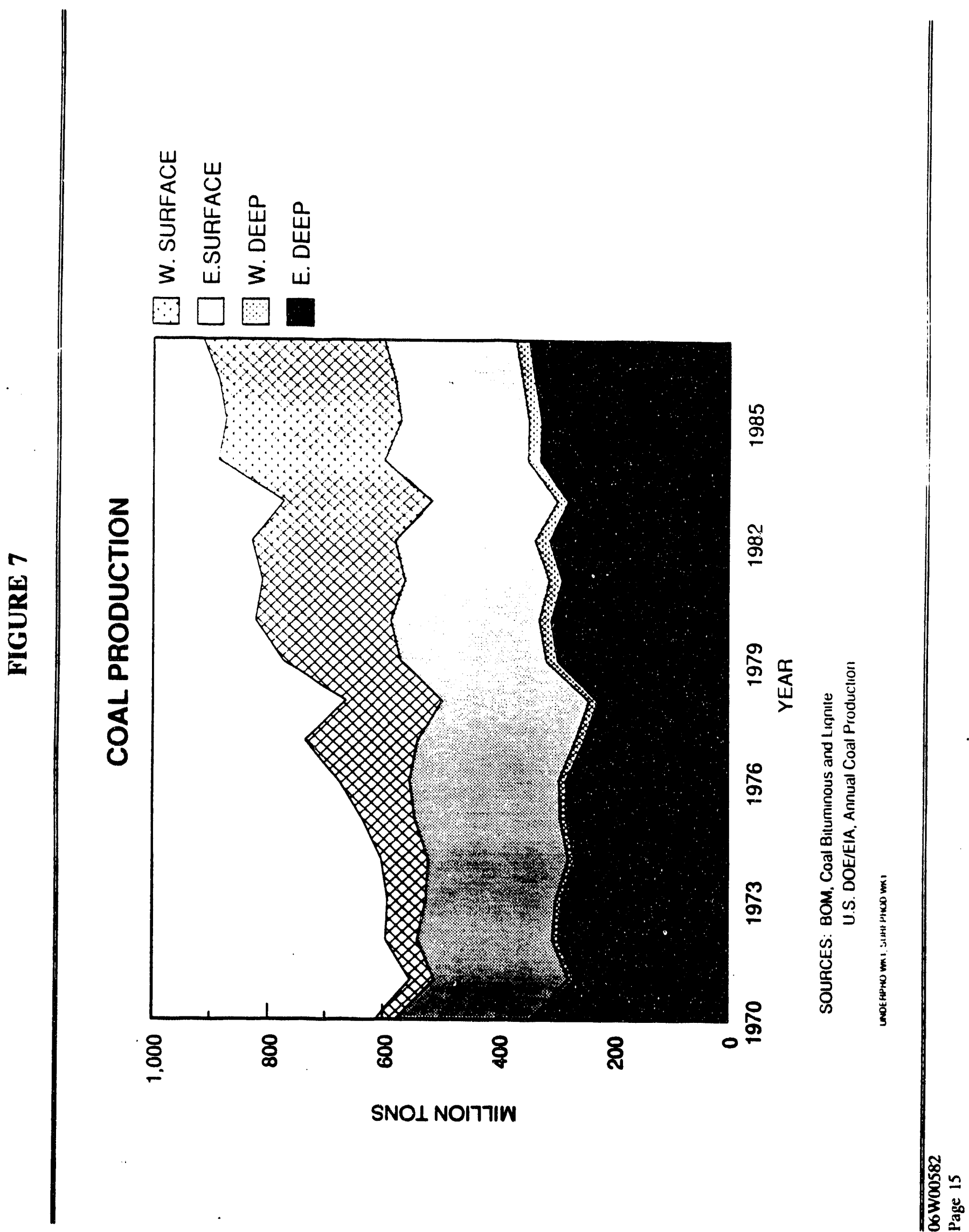


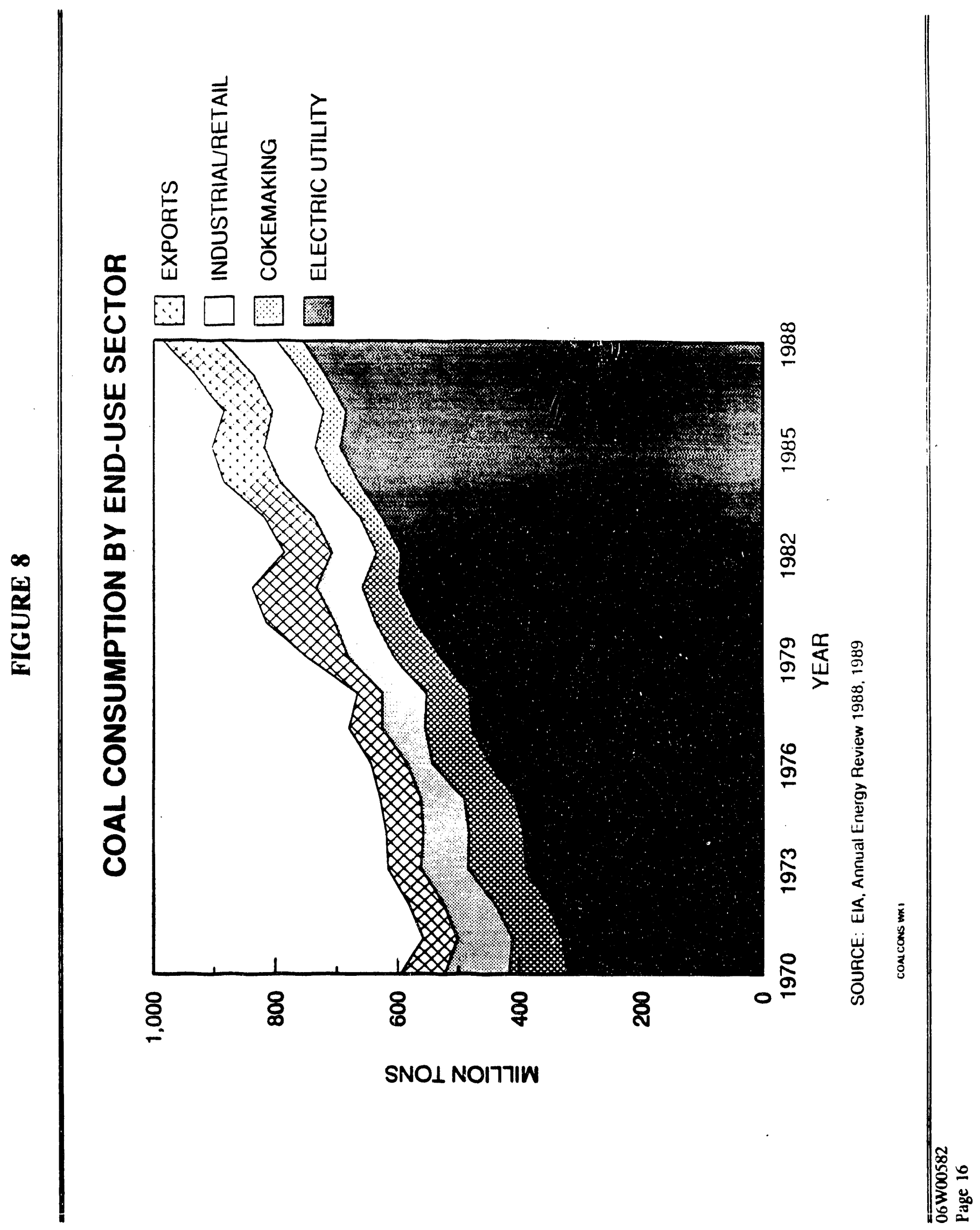


Coal-fired power plants are located in 44 states and accounted for 57 percent of the electricity generated in 1988. The larger plants burn around 5 million tons of coal each year. On average, each ton of coal generates 2,000 kilowatt-hours of electricity (one kilowatt-hour of electricity is enough to light 10 100-watt light bulbs for an hour).

The industrial sector is the next largest domestic consumer of coal. Industrial demands are mostly for steam production, cement and lime kiln use, and cogeneration. Demand in the industrial sector declined during the 1970 s but has shown moderate growth during the 1980 s. Consumption by industrial customers dropped by one-third, from 90 million tons in 1970 to a low of 60 million tons in 1980. Since then demand has risen and stood at 76 million tons in 1988.

The iron and steel industry, foundries, and other industries, which use coke made from metallurgical coal, now comprise the third largest domestic use of coal. Coke is made by heating a blend of metallurgical coals until an almost pure carbon product if formed. One ton of coal will yield about 1.400 pounds ( 0.7 tons) of coke and a variety of by-proaucts. Coke-making was once a larger market for coal. However, demand for metallurgical coals has fallen with the decline of U.S. iron and steel production levels, increased steel imports, improvements in blast-furnace technology. the increased use of scrap iron, and the increased substitution of steel by other products. Because of these factors, metallurgical coal demand has fallen from 96 million tons in 1970 to +2 million tons in 1988.

Minor amounts of coal are used domestically for transportation and for residential and commercial heating. These consuming sectors accounted for only 7.7 million tons in 1988, down from 16.4 million tons in 1970.

Steam and metallurgical coal exports account for approximately 10 percent of U.S. coal production and together now comprise the second largest sector after electric utilities. Export tonnages have varied widely, as low as 41 million short tons in 1978 and as high as 112 million tons in 1981. Ninety-five million tons were exported in 1988. Coal exports create positive economic. trade, and energy security effects for the U.S. In 1988 dollars, annual coal exports generated $\$ 2.6$ billion in 1970 and $\$ 3.1$ billion in 1988 . Unlike other energy sources, international coal trade creates a positive balance of payments for the U.S. (Figure 9).

\section{I.B U.S. COAL RESERVES}

Coal accounts for a dominant share of U.S. fossil fuel reserves and resources. The United States contains some of the world's major coal deposits. Coal, present in 38 States, underlies a total of 458,000 square miles (about 13 percent of the U.S. land area). Figure 10 is a map showing the locations of major U.S. coal fields. The coal found in these deposits are categorized into resources, reserve base, and reserves according to criteria set forth by the U.S. Geological Survey (U.S.G.S.) ${ }^{2 /}$ Coal resources encompass all naturally occurring concentrations of coal in such forms and amounts that economic extraction is currently or potentially feasible. U.S. coal resources total nearly four trillion short tons which is equivalent to nearly 90,000 quadrillion Btu of energy (Table 4).

2/ Wood, Gordon H., et. al., Coal Resource Classification System of the U.S. Geological Survey, Geological Survey Circular 891, 1983. 


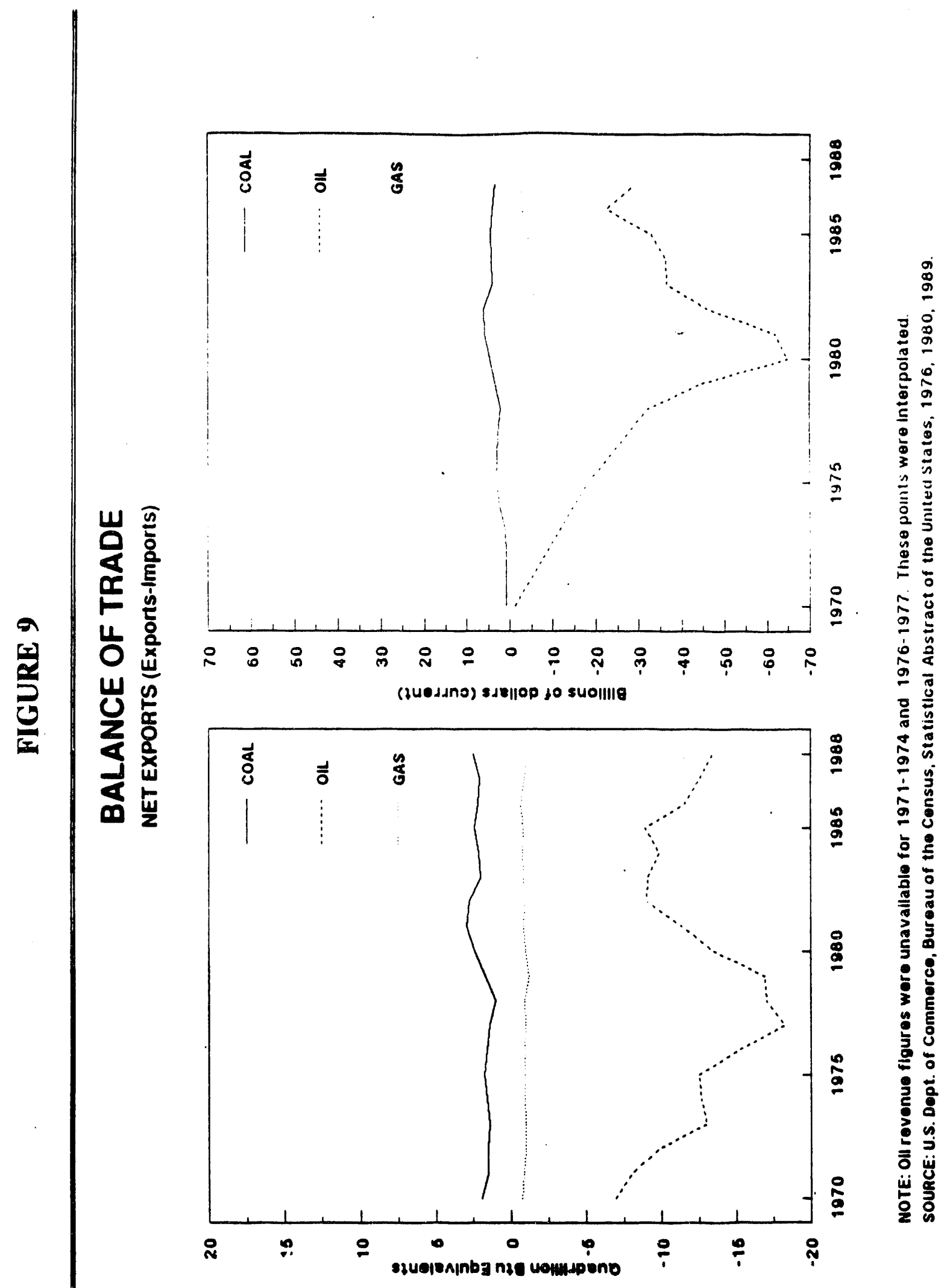




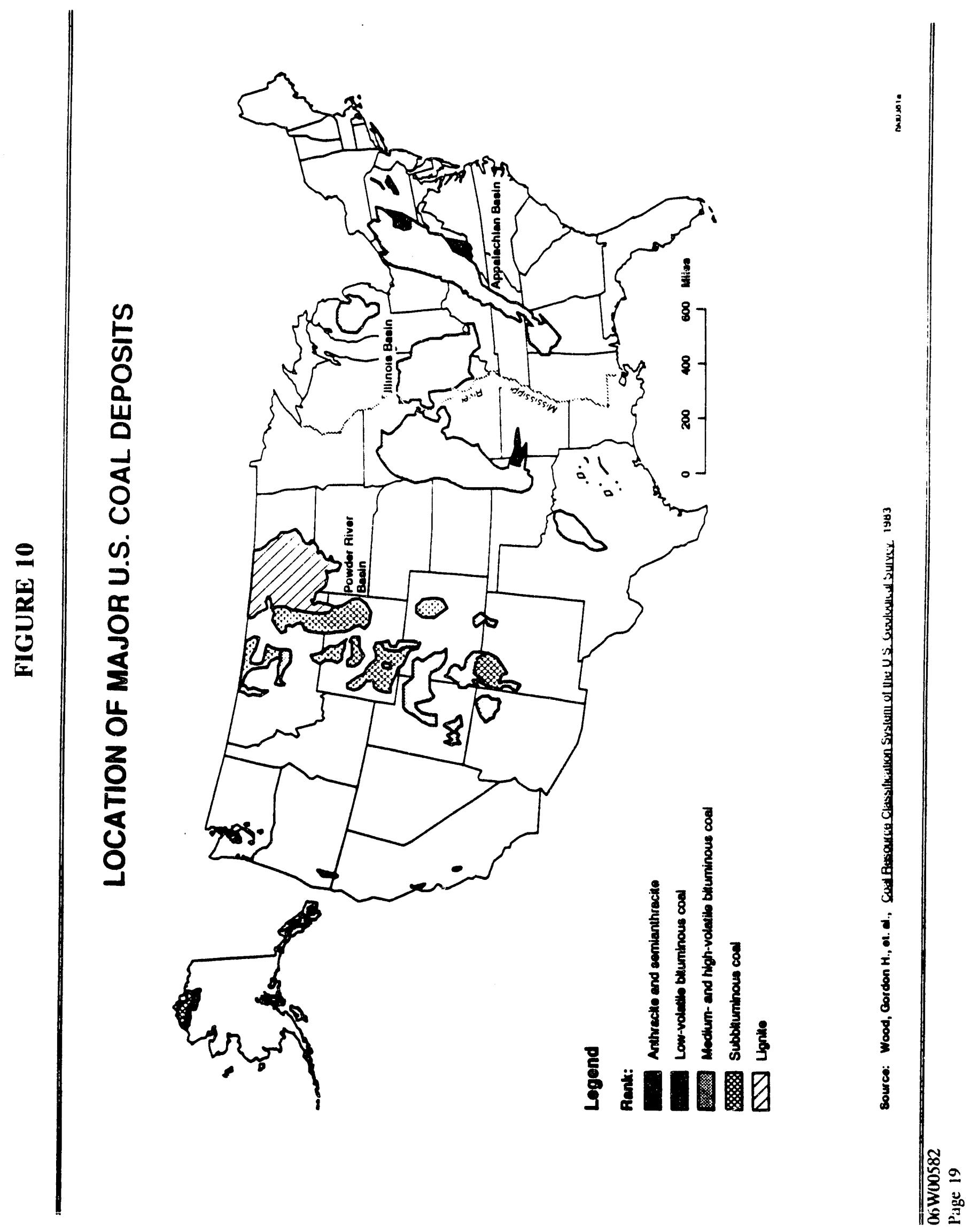




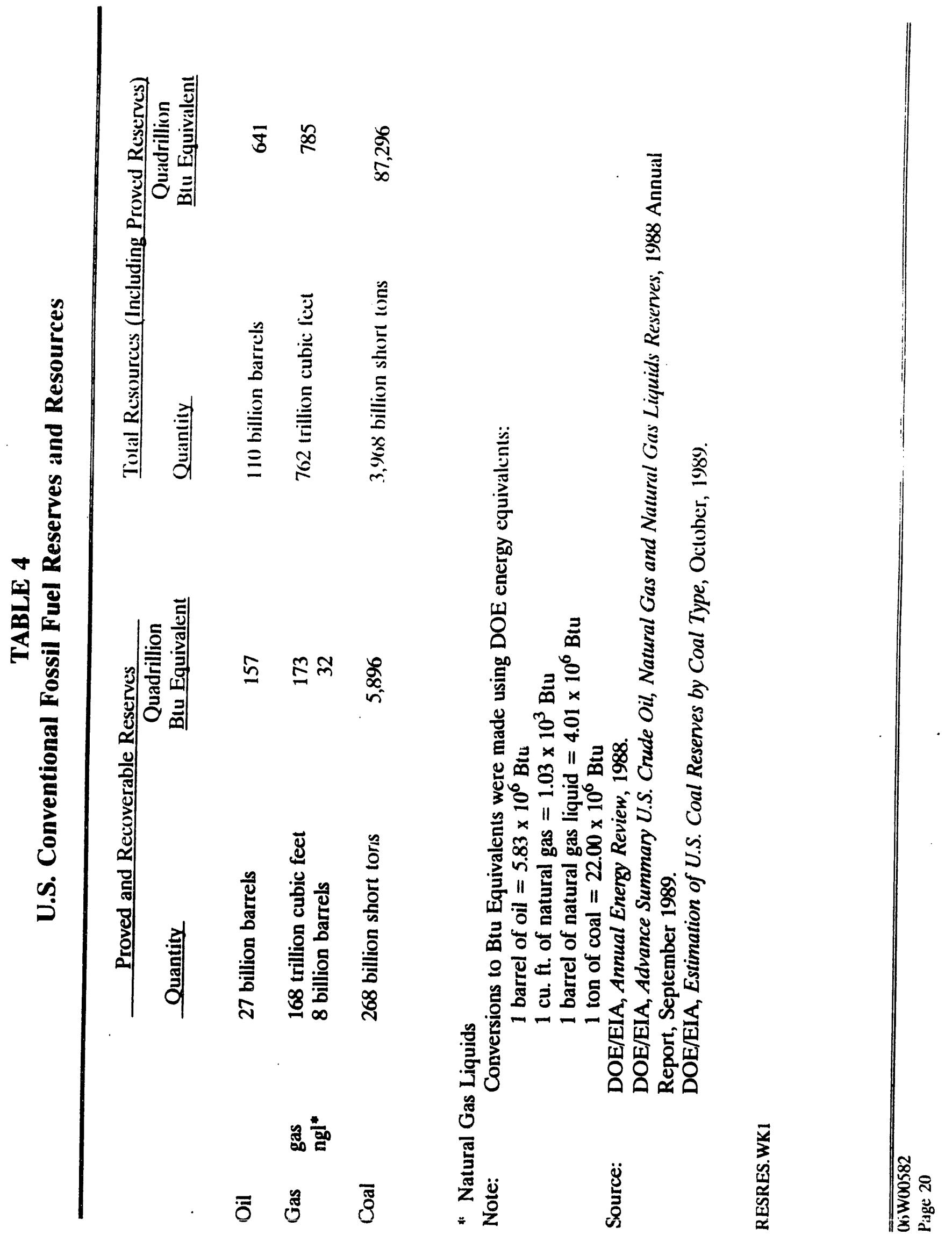


The reserve base represents the portion of resources that meet specified geologic and economic minability criteria related to current mining and production practices. These criteria involve coal quality, depth, thickness, rank, and distance from points of measurement. Depth and thickness limits are used as indicators to determine if the coal can be economically extracted. In 1988. the L'S. Demonstrated Reserve Base (DRB) contained 475 billion short tons of coal (Table 5).

The U.S. DRB contains roughly equal quantities of coal east and west of the Mississippi River. However, coal resources are much greater west of the Mississippi River, retlecting in part the relatively recent history of western coal exploration in contrast to the more extensively-explored eastern fields. Over time, with additional geologic definition, many of these resources will be reassigned to the DRB.

Recoverable reserves are those reserves in the DRB which are accessible to mining and can be physically recovered. Accessibility is detined by whether the coal reserves are available to mining. Certain portions of the DRB are inaccessible due to natural or manmade obstructions, and to environmental or legal restrictions. These reserves are removed from consideration before the application of recovery tactors to determine the portion of the coal that can be removed in the mining process. Recovery factors presently used by EIA to determine recoverable reserves are 60 percent recoverability for underground reserves and 80 percent and 90 percent. respectively. fior eastern and western surtace mines. These factors are based upon recovery rates submitted to ElA by coal-mine operators. Application of these factors to the accessible reserves result in the determination of recoverable reserves. The U.S. presently has 268 billion tons of recoverable reserves. Measured in Btu, this 5,896 quadrillion Btu of coal reserves is more than ten times the amount of U.S. oil and gas reserves.

U.S. coal reserves are huge relative to production and use. In terms of years' supply at current rates of production and consumption, U.S. coal reserves would be sufficient to sustain over 275 years of production at 1987 rates. Since the U.S. is a net exporter of coal, domestic consumption is less than production, such that over 300 years of consumption could be sustained.

On a global basis, the U.S. has a large percentage of coal reserves but only a small percentage of oil and gas reserves. Over one-quarter of the world's recoverable coal reserves are in the U.S. By contrast. U.S. oil reserves are only about 3 percent of the world total, and U.S. gas reserves comprise about 5 percent of the world total (Figure 11).

In general, the coal found in the various coal provinces of the U.S. are evaluated according to their rank and the mining method used to extract the coal. Coal rank refers to the classification of the coal according to their degree of metamorphism, progressive alteration, or coalification (maturation). Higher rank coals correspond to purer forms of coal and typically contain more Btu per pound. There are four basic ranks: anthracite, bituminous, subbituminous, and lignite. Table 6 presents the U.S. Geological Survey's (U.S.G.S.) criteria for each rank and subclassifications. The fixed carbon criteria defines the amount of solid combustible material in the coal. Volatile matter refers to the amount of gasses, also a source of energy, associated with the coal. Finally, calorific value refers to the amount of energy (Btu) generated from burning the coal after removal of excess rock or ash (defined as mineral-matter-free) and with only the inherent moisture content. 


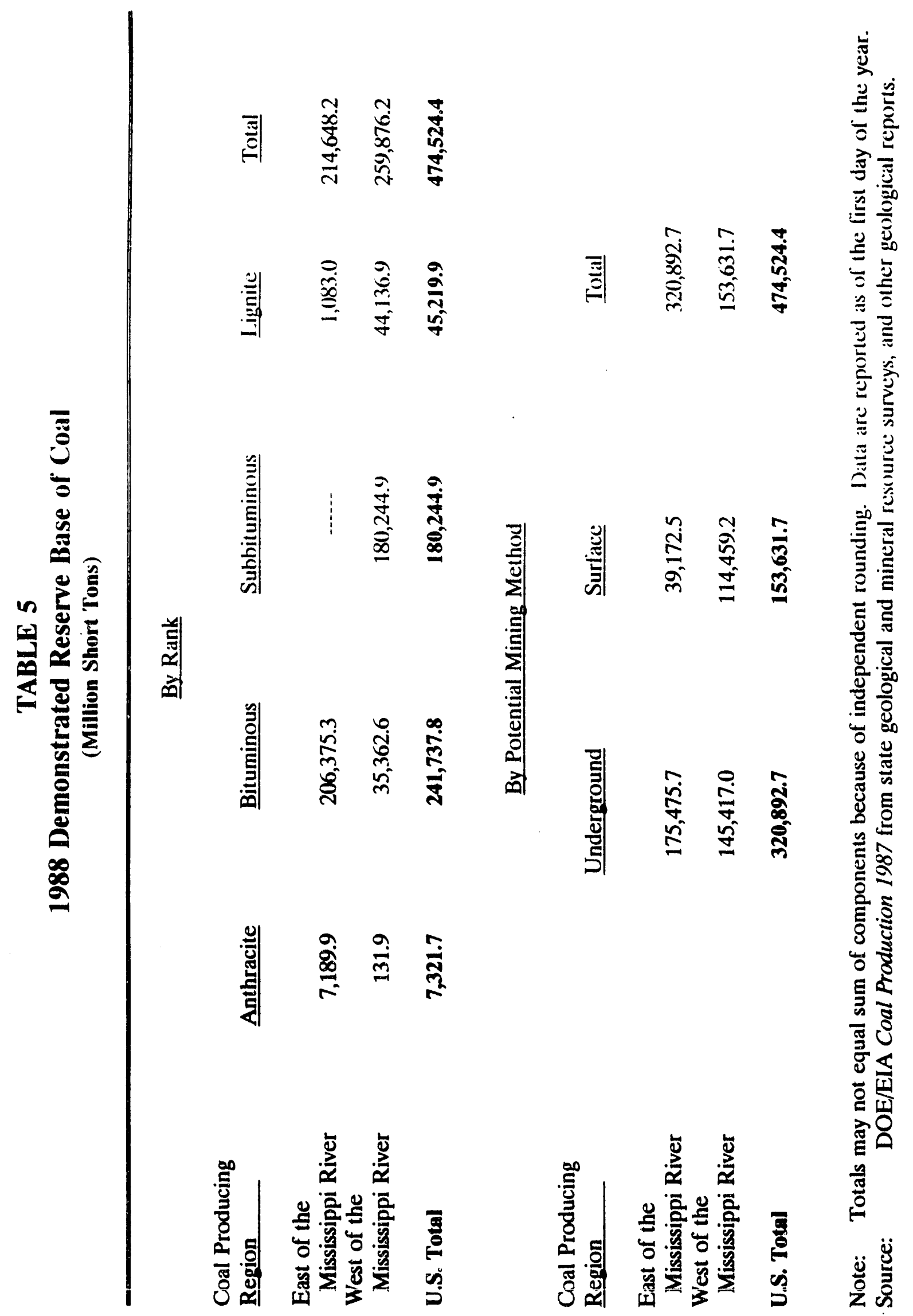



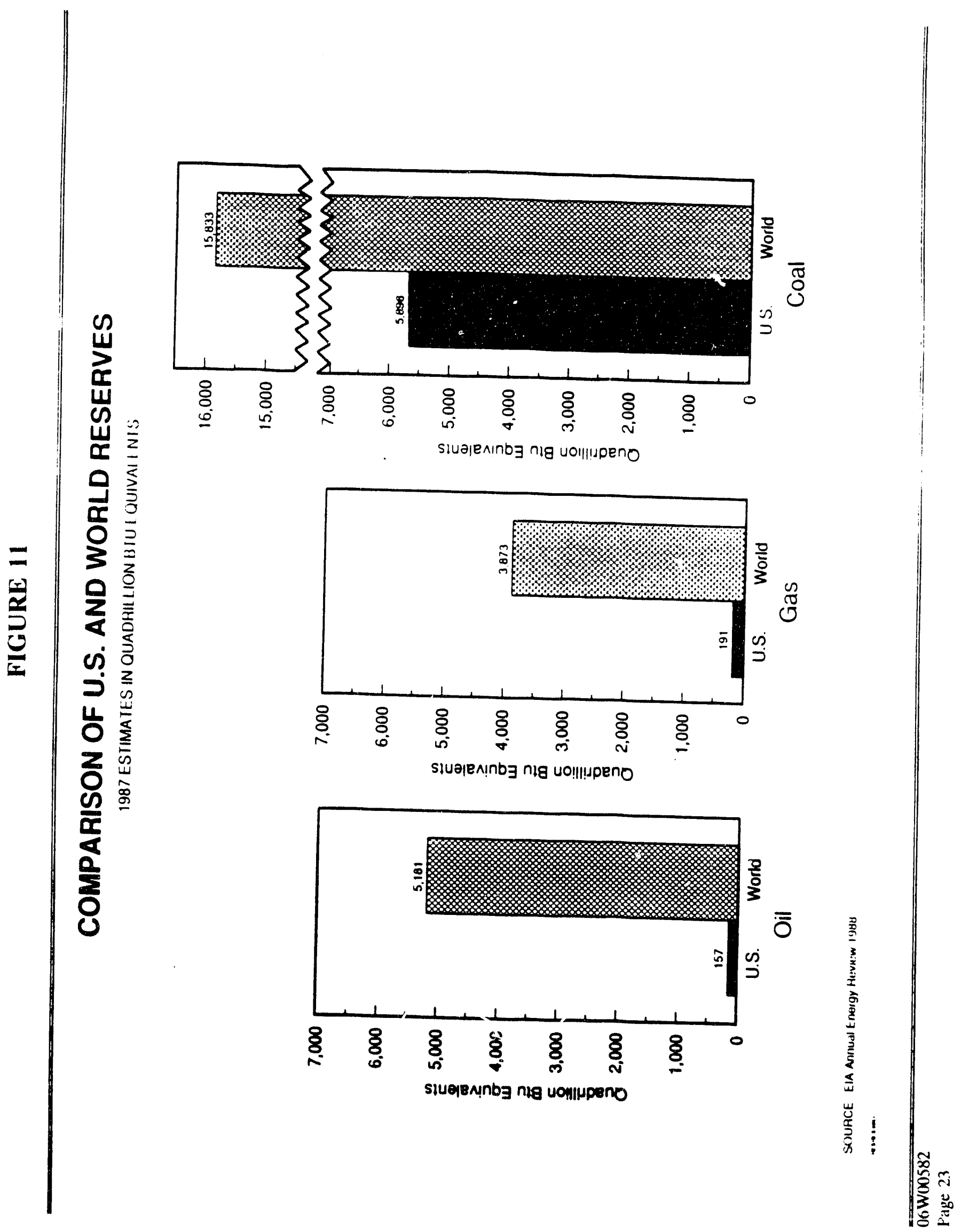


\section{TABLE 6 \\ Classification of Coals by $\operatorname{Rank}^{\mathrm{A}, 1}$}

\begin{tabular}{|c|c|c|c|c|c|c|c|c|}
\hline \multirow[b]{2}{*}{ Class } & \multirow[b]{2}{*}{ Group } & \multicolumn{2}{|c|}{$\begin{array}{c}\text { Fixed Carbon } \\
\text { Limits, percent } \\
\text { (Dry, Mineral- } \\
\text { Matter-Free Basis) }\end{array}$} & \multicolumn{2}{|c|}{$\begin{array}{l}\text { Volatile Matter } \\
\text { Limits, percent } \\
\text { (Dry, Mineral- } \\
\text { Matter-Free Basis) }\end{array}$} & \multicolumn{2}{|c|}{$\begin{array}{l}\text { Calorific Value } \\
\text { Limits BTT per } \\
\text { pound (Moist. }^{B} \\
\text { Mineral-Matter- } \\
\text { Free Basis }\end{array}$} & \multirow[b]{2}{*}{$\begin{array}{l}\text { Agglomerating } \\
\text { Chatracter }\end{array}$} \\
\hline & & $\begin{array}{l}\text { Equal } \\
\text { or } \\
\text { Greater } \\
\text { Than }\end{array}$ & $\begin{array}{l}\text { Less } \\
\text { Than }\end{array}$ & $\begin{array}{c}\text { Greater } \\
\text { Than }\end{array}$ & $\begin{array}{l}\text { Equal } \\
\text { or } \\
\text { Less } \\
\text { Than }\end{array}$ & $\begin{array}{l}\text { Equal } \\
\text { or } \\
\text { Greater } \\
\text { Than }\end{array}$ & Less & \\
\hline 1. Anthracite" & $\begin{array}{l}\text { 1. } \quad \text { Meta-anihracite } \\
\text { 2. Anthracite } \\
\text { 3. } \\
\text { Semianthracite }\end{array}$ & $\begin{array}{l}98 \\
92 \\
86\end{array}$ & $\overline{98}$ & $\overline{2}$ & $\begin{array}{c}2 \\
8 \\
14\end{array}$ & $\overline{-}$ & $\overline{-}$ & $\begin{array}{l}\text { \}nonagg(n)merating } \\
\}\end{array}$ \\
\hline II. Bituminous & $\begin{array}{ll}\text { 1. } & \text { Low volatile } \\
\text { bituminous coal } \\
\text { 2. } \\
\text { Medium volatile } \\
\text { hituminous coal } \\
\text { 3. High volatile } \underline{A} \\
\text { bituminous coal } \\
\text { 4. High volatile } \underline{B} \\
\text { bituminous coal } \\
\text { 5. High volatile } \underline{\mathrm{C}} \\
\text { bituminous coal }\end{array}$ & $\begin{array}{l}73 \\
69 \\
-\end{array}$ & $\begin{array}{l}36 \\
-3 \\
69 \\
- \\
-\end{array}$ & $\begin{array}{l}14 \\
22 \\
31 \\
- \\
-\end{array}$ & $\begin{array}{l}22 \\
31 \\
- \\
-\end{array}$ & $\begin{array}{c}- \\
- \\
14000^{D} \\
13000^{D} \\
11500 \\
10500\end{array}$ & $\begin{array}{l}- \\
- \\
- \\
14000 \\
13000 \\
11500\end{array}$ & 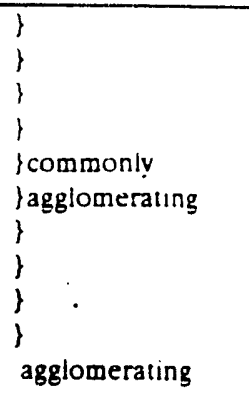 \\
\hline III. Subbituminous & $\begin{array}{ll}\text { 1. } & \text { Subbituminous } \underline{\mathbf{A}} \\
\text { coal } \\
\text { 2. } \\
\text { Subbituminous } \underline{\mathbf{B}} \\
\text { coal } \\
\text { 3. } \begin{array}{l}\text { Subtituminous } \underline{\mathbf{C}} \\
\text { coal }\end{array} \\
\end{array}$ & - & - & - & - & $\begin{array}{l}10500 \\
9500 \\
8300\end{array}$ & $\begin{array}{r}11500 \\
10500 \\
9500 \\
-\quad 3\end{array}$ & 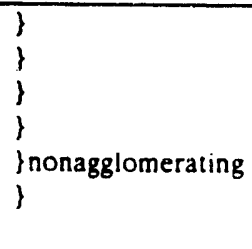 \\
\hline IV. Lignite & $\begin{array}{ll}\text { 1. } & \text { Lignite } \\
\text { 2. } & \text { Lignite } \underline{B}\end{array}$ & - & - & - & - & 6300 & $\begin{array}{l}8300 \\
6300\end{array}$ & $\begin{array}{l}\} \\
\}\end{array}$ \\
\hline
\end{tabular}

t This classification does not include a few coals, principally nonbanded varieties, which bave unusual physical and chemical properties and which come within the limits of fixed carbon or calorific value of the high-volatile bituminous and subbituminous ranks. All of these either contain les than 48 percent dry, mineral-matter-free fixed carbons or have more than 15500 moist mineral-matter-free British thermal units per pound.

B Moist refen to coal containing its natural inherent moisture but not including visible water on the surface of the cosl.

C If agglowerating, clavify in low-volatile group of the bituminous clase.

D Coals having 69 percent or more fixed carbon on the dry, mineral-matter-free basis shall be clawaified according to fixed carbon. regardlese of calorific value.

E It is recognized that there may be nomaglomerating varieties in these group of the bituminous class, and there are notable exceptions in the high-volatile $\underline{C}$ bituminous group.

ASTM, 1981, p. 215.

- Modified from ASTM, 1981.

Source: Wood, Gordon, H, et al., Cosl Resource Classification System of the U.S. Geolorical Survey, U.S.G.S. Circular 891, 1983. 
Most of the older, higher-rank coals are in the east. These reserves are located mostly in the Appalachian and Illinois Basins. Historically, most of the U.S.'s coal production has come from the Appalachian Basin, which accounted for almost three-fourths of the annual production as recently as 1970. It remains today the major source of bituminous coal and anthracite. Most of the rest of bituminuus coal production comes from the Illinois Basin. whose coals have higher sulfur and ash contents; a hinderance to their use both as a fuel and as metallurgical coal. The coal in both these basins was formed from organic matter deposited during the Pennsylvanian period of the Earth's history, or about 300 million years ago (just before the formation of the Appalachian Mountains) (Figure 12).

By contrast. many of the coals in the western U.S. are much younger, forming from material deposited less than 140 million years ago during the Cretaceous and Tertiary periods (about the time of the extinction of dinosaurs). These coals are, in general, less mature than the coals in the east and have lower ranks of lignite to subbituminous. Some bituminous coal exists and is produced in parts of the Rocky Mountain region, as shown in Figure 10. These amount to less than 10 percent of total bituminous coal production. Subbituminous coal production dominates, especially in the Powder River Basin of Wyoming and Montana with lesser volumes produced in parts of the Rocky Mountain region and Alaska. Lignite, a low-rank coal, is produced mostly in the Gulf region (primarily Texas) and in North Dakota.

Based upon potential methods of mining (underground extraction verses surface mining), about two-thirds of the coal is minable using underground techniques. These reserves are split tairly evenly between the east and the west. The remaining one-third of the Demonstrated Reserve Base is classified as surface-minabie, and most of this is west of the Mississippi River (Table 5).

Another regionally-based factor is sulfur content. If not removed during coal preparation or from flue gases $3 /$ the sulfur is emitted to the atmosphere as $\mathrm{SO}_{2}$. As past and proposed legislative and regulatory restrictions have limited (and may further limit) $\mathrm{SO}_{2}$ emissions, regions capable of producing low-sulfur coals have had (and will likely have) further demands placed upon them. In the east, low-sulfur coal reserves are located primarily in the Central Appalachian region of eastern Kentucky, southern West Virginia, western Virginia, and Tennessee. In the west, low sulfur bituminnus coals are found in the Rocky Mountain region, and low-sulfur subbituminous coals in the Powder River Basin (Table 7).

While U.S. coal reserves are massive, their costs of extraction vary broadly. The economics of resource depletion suggest that the more economic seams (e.g., thicker seams, closer to the surface) are generally mined first, such that over time new mining operations will progressively move to thinner and deeper seams. Long-term trends in mining indicate that this has generally been the case. In and of itself, this resource depletion effect would suggest that coal mining costs would increase over time as the best seams are used up first. For surface mining, this depletion effect can be observed as a gradual increase in overburden ratios, the cubic yards of overlying material removed per ton of coal mined (Table 8). However, technology improvements and gains in labor productivity have usually been sufficient to offset the effects of resource depletion on the total cost of mining coal.

3/ Flue gases are gases created during coal combustion and contain pollutants that can escape through the stacks unless they are removed. 


\section{FIGURE 12}

\section{GEOLOGIC AGES FOR THE DEPOSITION OF SIGNIFICANT U.S. COAL FIELDS}

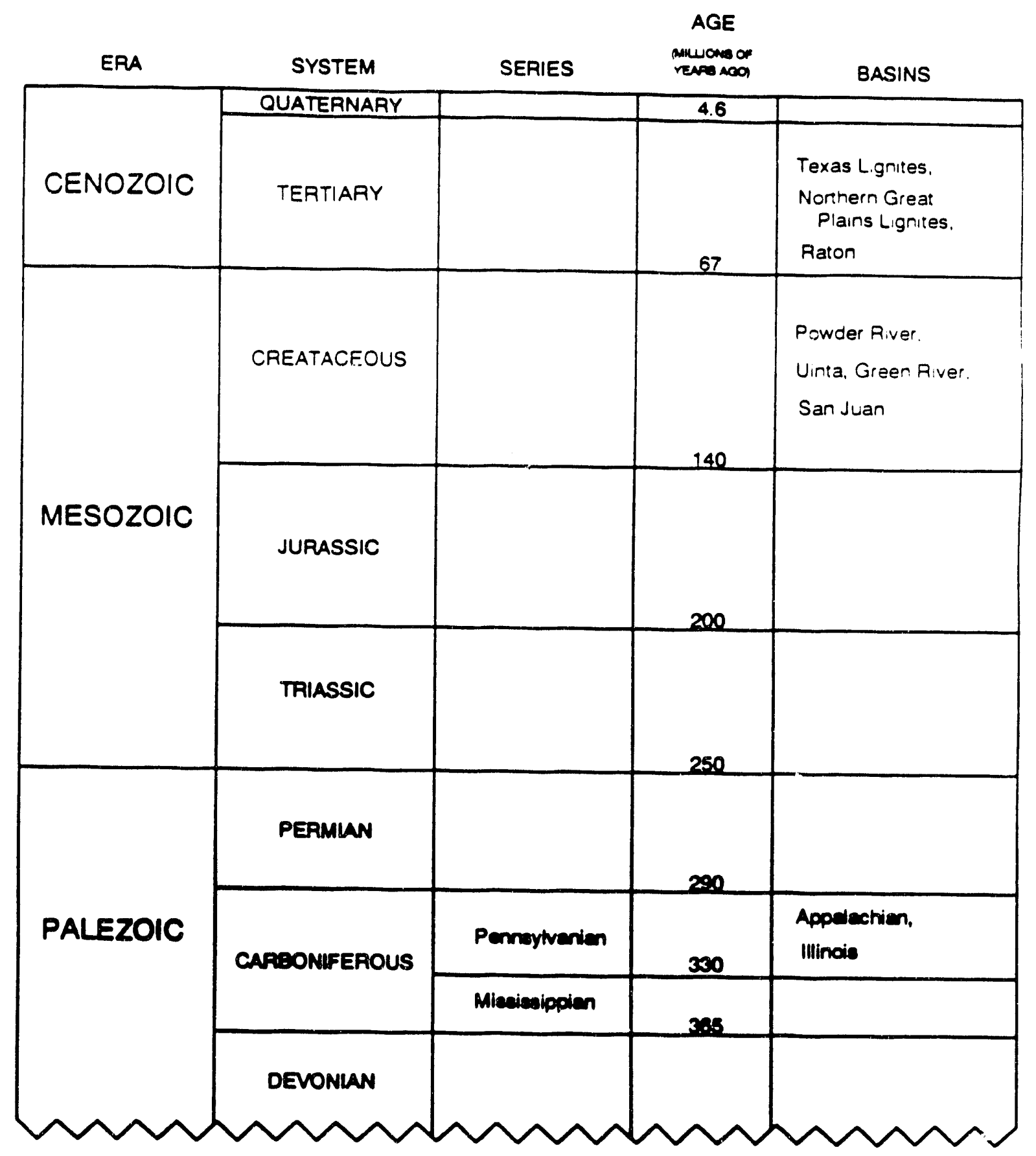

Source: Beased upon cod seam descriptions

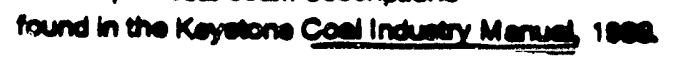




\section{TABLE 7}

\section{Estimates of 1987 Demonstrated Reserve Base by Coal Type and Region (Million Short Tons)}

\begin{tabular}{|c|c|c|c|c|}
\hline \multirow[b]{2}{*}{ Region } & \multicolumn{3}{|c|}{$\begin{array}{c}\text { Sulfur Content } \\
\text { (pounds per million Btu) }\end{array}$} & \multirow[b]{2}{*}{ Total } \\
\hline & $\begin{array}{l}\leq 0.60 \\
\text { (Low Sulfur) }\end{array}$ & $\begin{array}{c}0.61-1.67 \\
\text { (Medium Sulfur) }\end{array}$ & $\begin{array}{l}\geq 1.68 \\
\text { (High Sulfur) }\end{array}$ & \\
\hline Appalachia & $21,526.2$ & 37.338 .5 & $39,830.9$ & 98.695 .6 \\
\hline Interior & $1,169.9$ & 21.547 .1 & $112,093.1$ & 134.810 .1 \\
\hline West & $133,959.1$ & $87,946.8$ & $11,638.4$ & 233.544 .3 \\
\hline U.S. Total & 156.655 .2 & $146,832.4$ & $163,562.4$ & 467.050 .0 \\
\hline
\end{tabular}

Note: $\quad$ Totals may not equal sum of components due to independent rounding.

Source: $\quad$ Energy Information Administration, Estimation of U.S. Coal Reserves by Coal Type, 1989. 


\section{TABLE 8}

\section{Average Overburden Ratios of Major Surface Mining States}

$\left(\mathbf{y d}^{3} /\right.$ net ton)

$\begin{array}{lccc} & \underline{1946} & \underline{1965} & \underline{1983} \\ \text { Illinois } & 12 & 14 & 16 \\ \text { Indiana } & 10 & 14 & 19 \\ \text { Kentucky } & 6 & 9 & 15 \\ \text { Ohio } & 8 & 14 & 22 \\ \text { Pennsylvania } & 9 & 18 & 20 \\ \text { W. Virginia } & 6 & 11 & 13 \\ \text { Wyoming } & 2 & 3 & 3\end{array}$

Source: $\quad 1946$ \& 1965 - Young, W.H., Thickness of Bituminous Coal and Lignite Seams Mined in 1965, BOM-IC 8345, 1967.

1983 - EIA, Coal Data: A Reference, 1985. 


\section{I.C PRODUCTIVITY}

For both surface and deep mines. labor and related costs often comprise the major expense of production. Consequently, the costs of coal mining tend to be inversely correlated with mining labor productivity (Figure 13).

From the late-1960s through the late 1970s, productivity in coal mining decreased sharply, more so than for any other major industry (Figure 14). Several factors contributed to this decline. including a rapid expansion of the work force, unstable labor-management relations, and adaptation to new health, safety, and environmental regulations.

In order to offset declining productivity and to meet new production demands, the coal industry labor force increased sharply during the 1970 s. Largely due to rapidly declining productivity. eastern underground mines had to substantially increase employment just to maintain production levels (Figure 15). The average cost of coal similarly rose sharply.

Beginning in the late 1970s, the slide in labor productivity ceased and began to rise rapidly. Many factors spurred this increase, including cost pressures brought about by coal mining overcapacity (and. more recently, lower oil and gas prices). improvement in labor-management relations, adaptation to new safety and environmental regulations, and further advances in mining technology. Average worker productivity has roughly doubled since the late 1970 s.

The growth in labor productivity has been faster than the growth in coal demand, and as a result the size of the labor force has declined since the late 1970s. In 1978, a coal mining labor force of 245,767 workers produced a total of 670 million tons. In 1988, despite a rise in total coal production of about 45 percent, coal mining employment had fallen to a little more than half of 1978 levels (Figure 16).

Technology has been a key factor underlying productivity gains over the long term. In both underground and surface mining, the development of larger, faster, and more efficient machines and mining methods has made coal mining a far less labor-intensive industry than it once was (Figure 17).

These same technology improvements have also contributed to reducing coal mining accidents. Fatal accidents from coal mining have been on the decline since early in this century (Figure 18). In 1988, only 44 fatalities were reported by the Mine Safety and Health Administration, an all time low.

This decrease is the result of increased mechanization, roof bolting, and more stringent safety regulations and practices. Improvements in mine ventilation technology prevents methane accumulation in the mine and removes coal dust. Coal dust is also controlled by watersprays and "rockdusting" with pulverized limestone to make it noncombustible. The introduction of roofbolting in the late 1950 s and subsequent technical improvements have significantly decreased roof falls, the single most frequent cause of fatal accidents in U.S. coal mines. Today's labor force is roughly ten times more productive than that at the beginning of the century, with vastly better health, safety, and working conditions (Figure 19). 


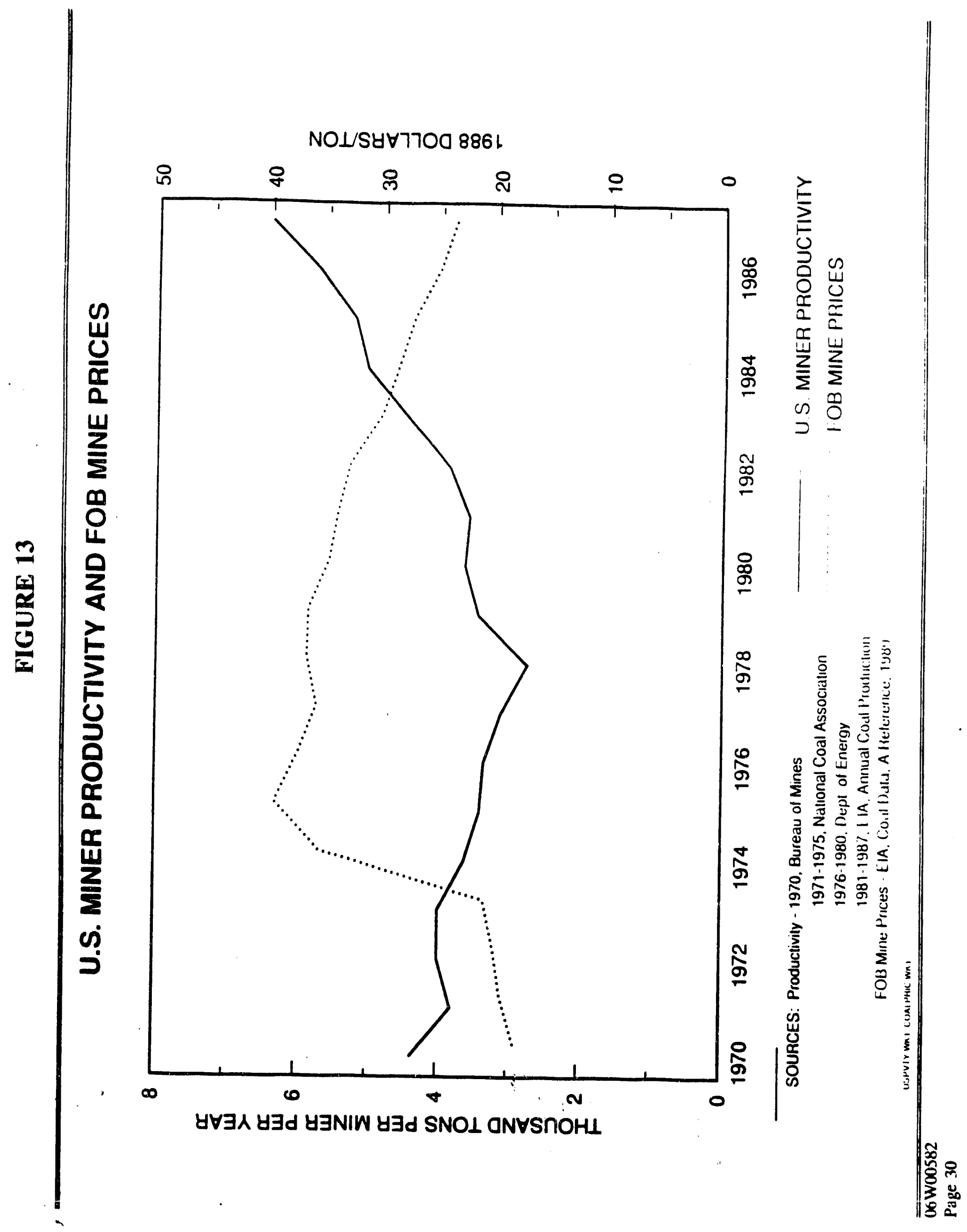




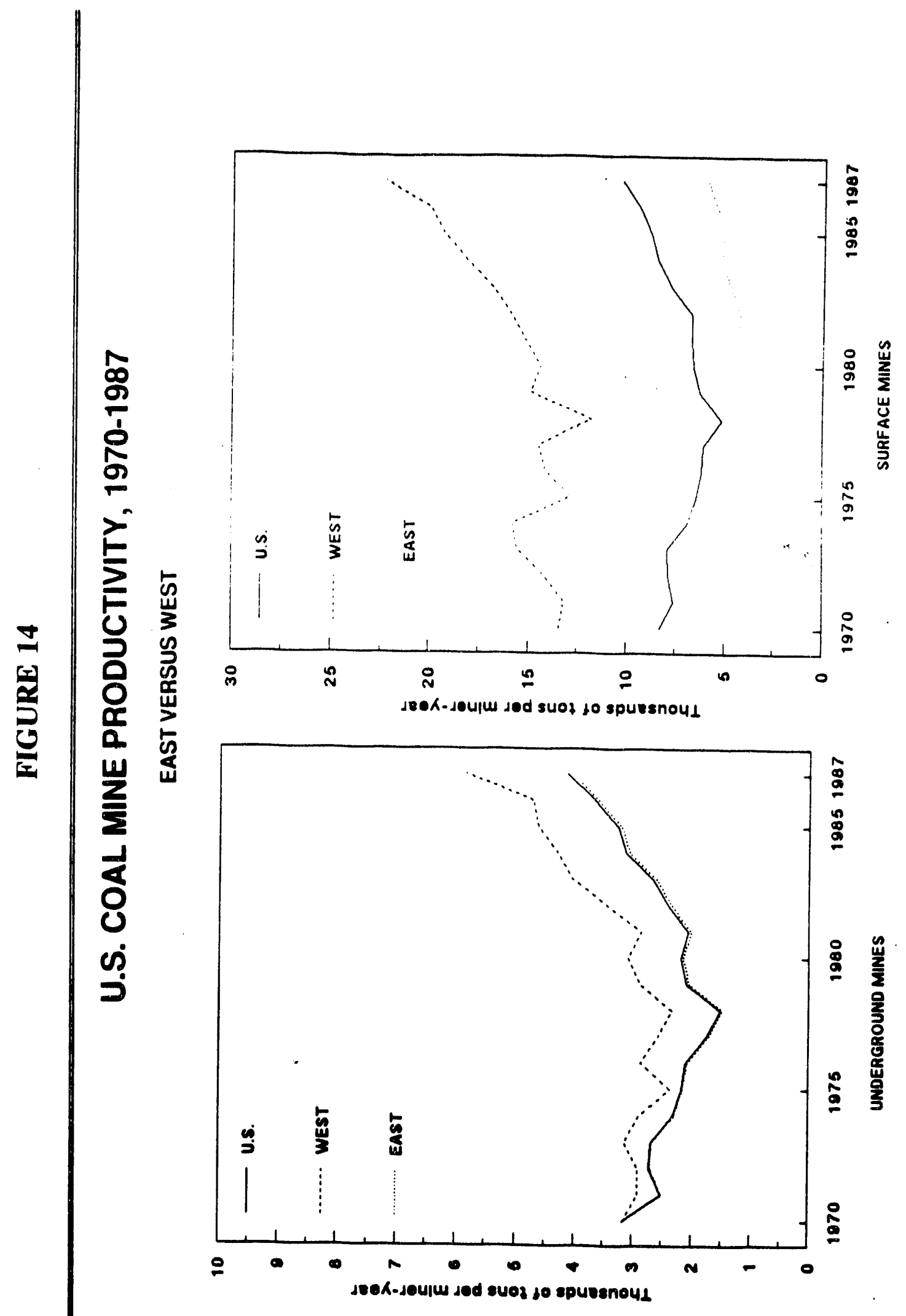

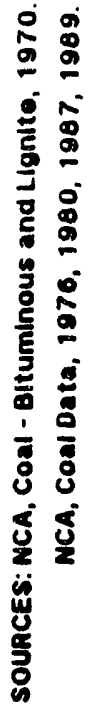




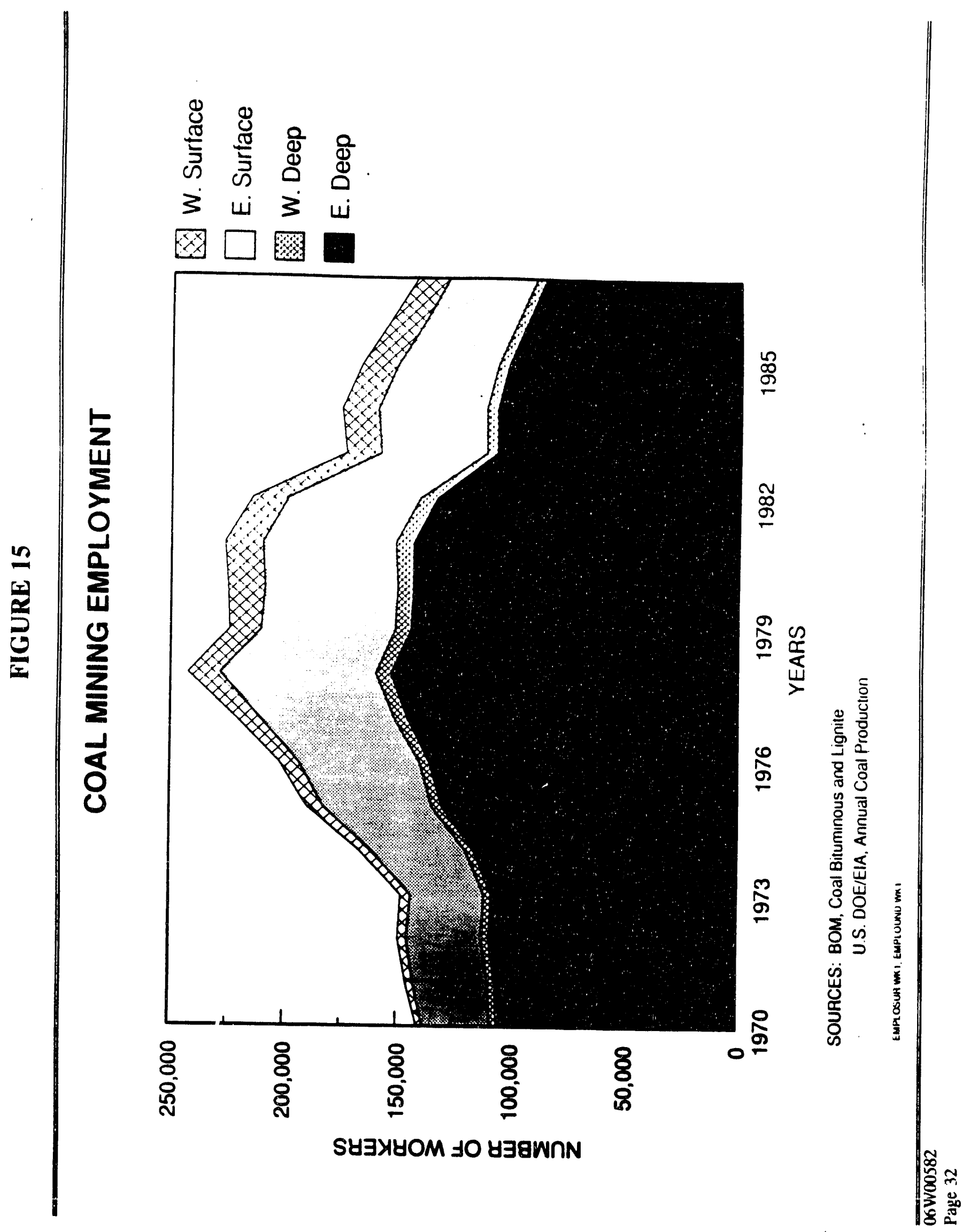



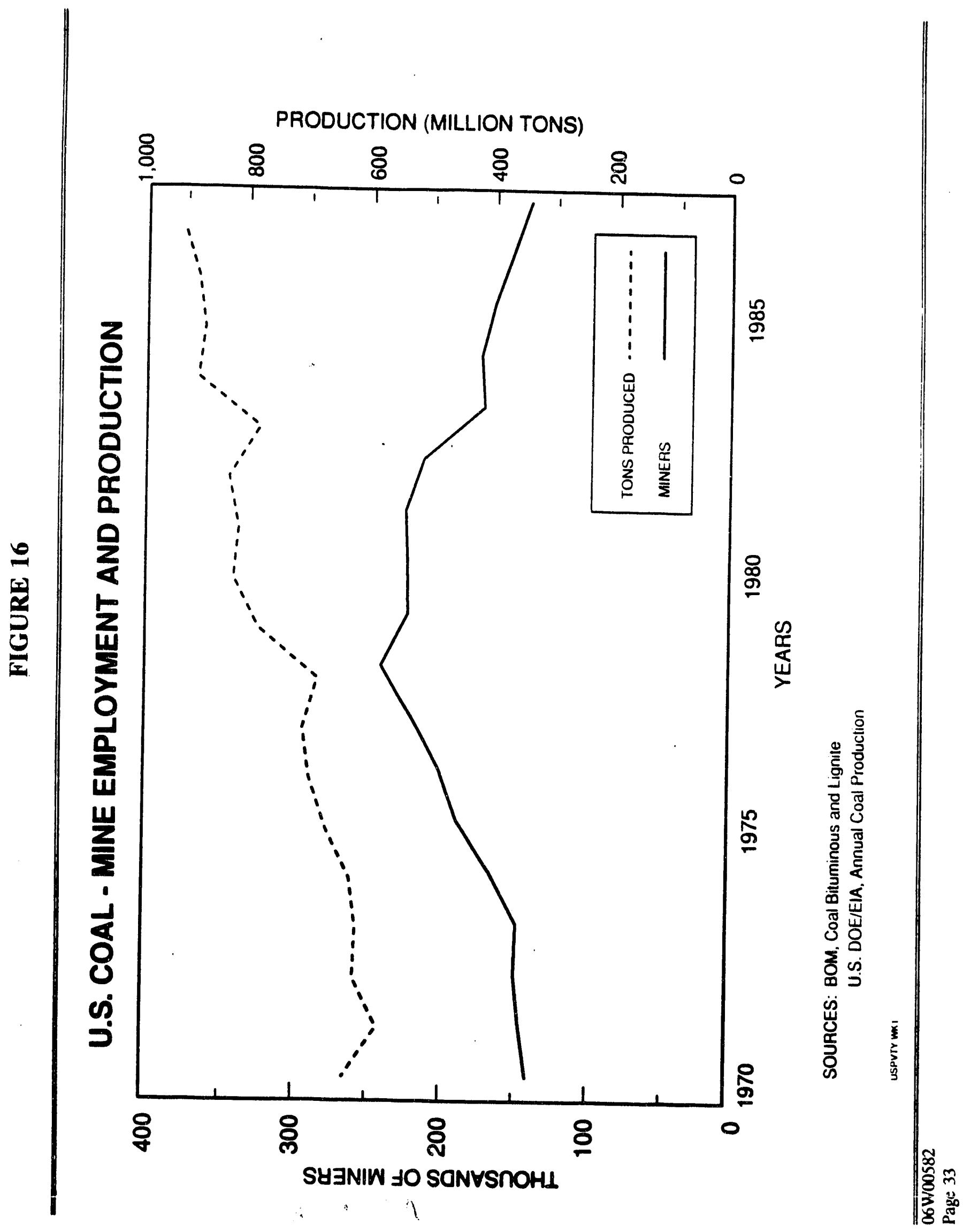


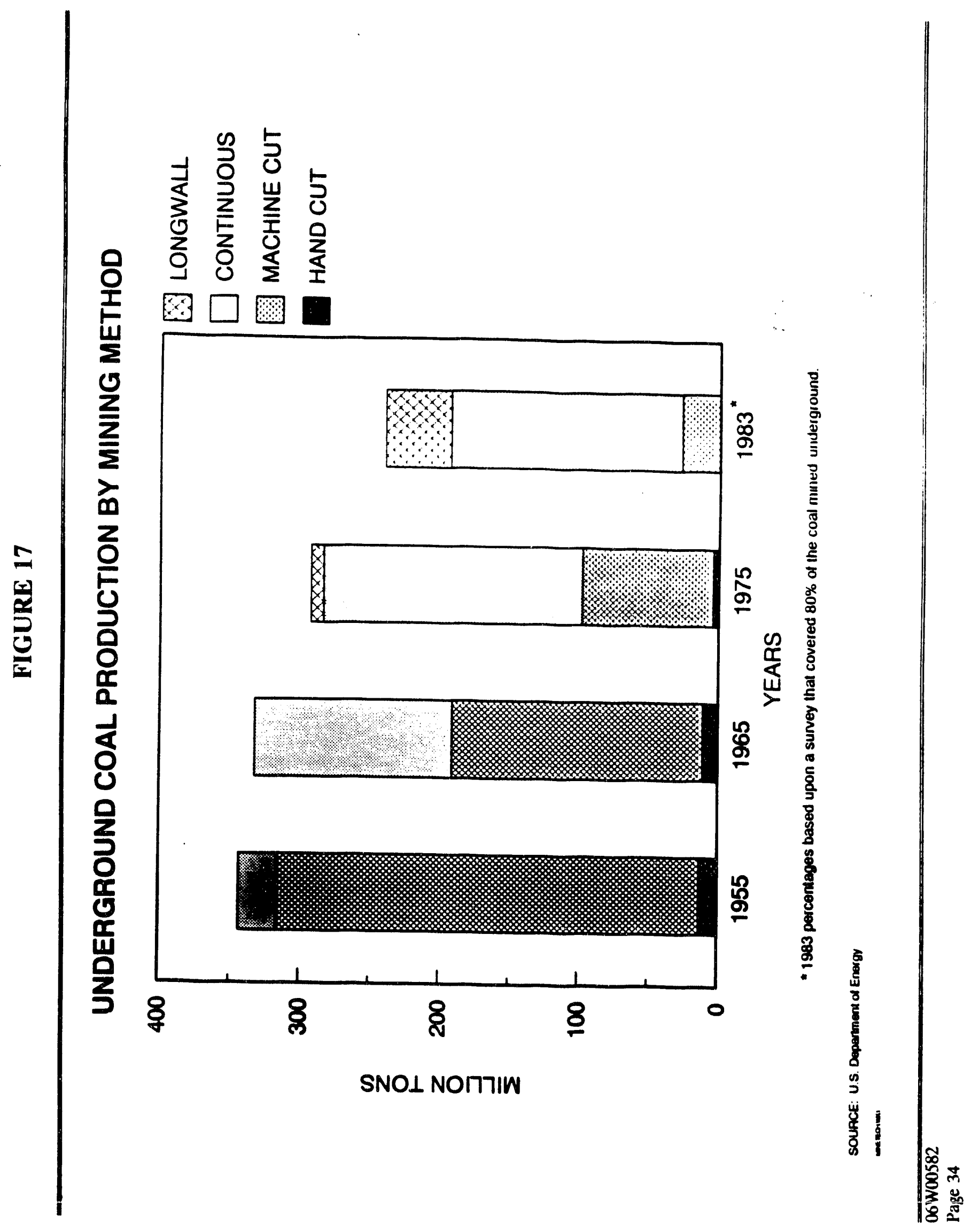




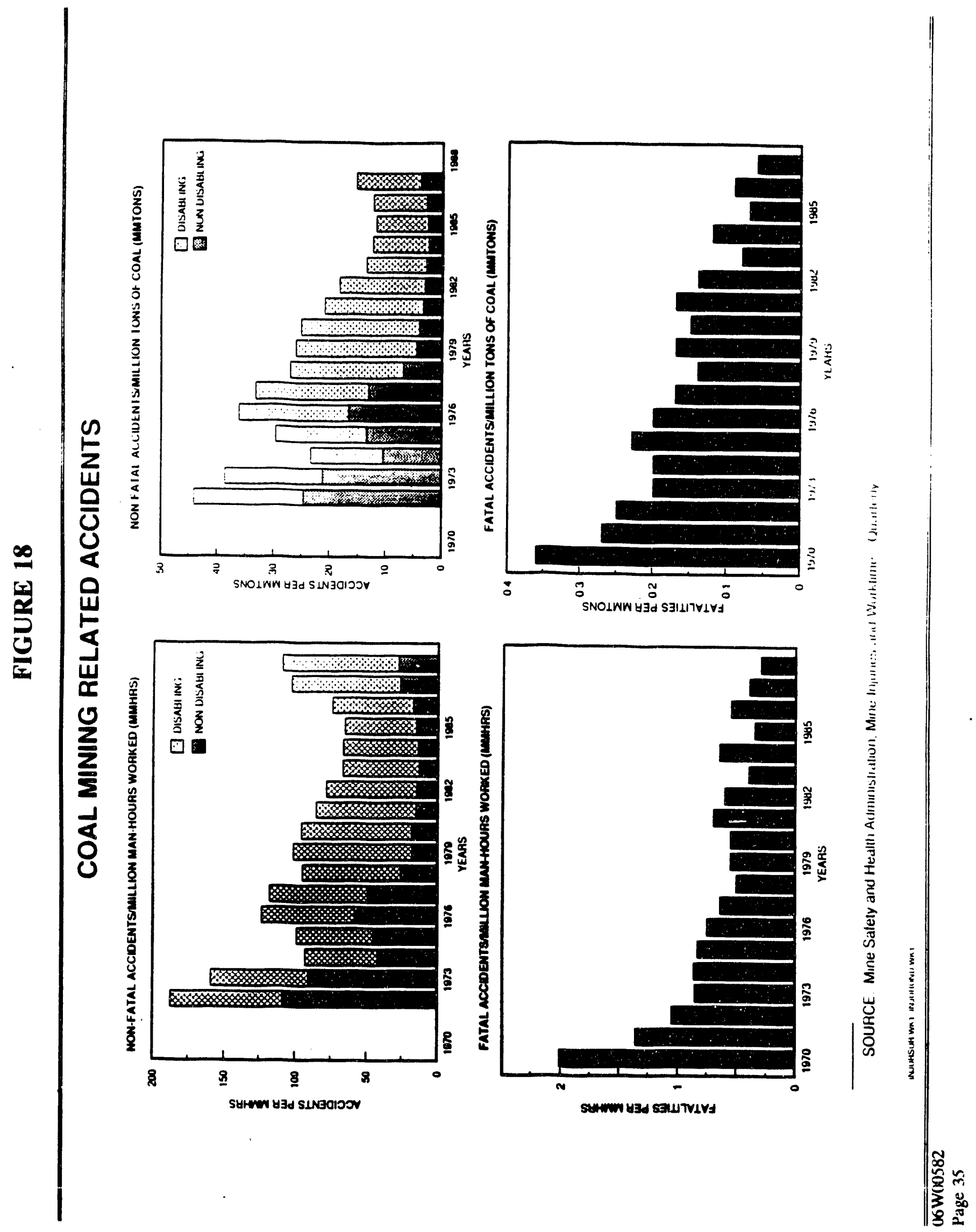




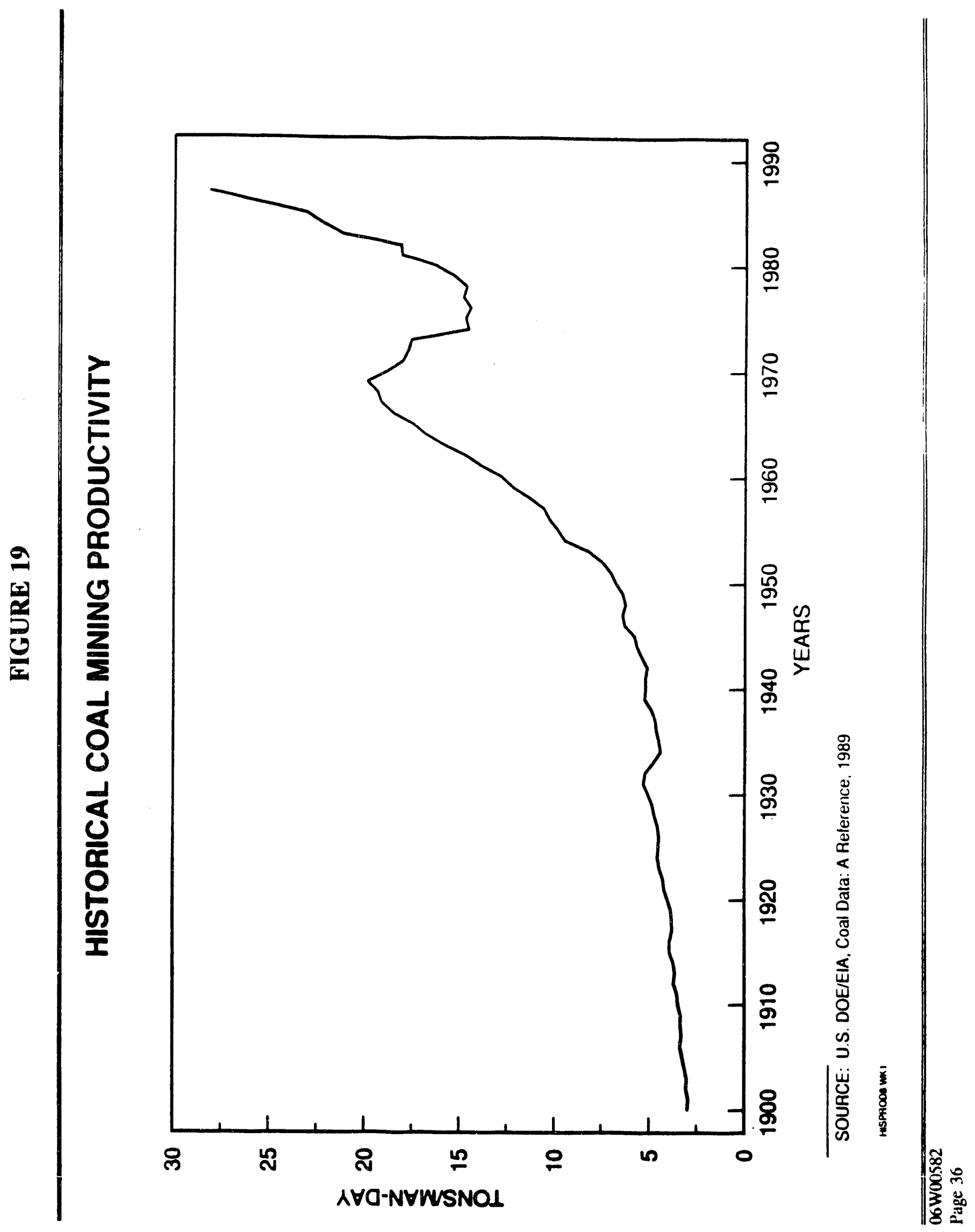


The rise in productivity has also effectively increased the capacity of many mines. This increase in capacity, relative to a moderate rise in demand, has kept the coal industry in an overcapacity situation, thereby maintaining competitive pressures to further increase productivity and reduce costs.

\section{I.D COST OF PRODUCTION}

Since the mid-1970s, the costs of mining coal have declined substantially in inflation-adjusted dollars. These lower coal mining costs have generally been passed on to the consumers in the form of lower prices, as the coal industry is a highly competitive industry. Adjusted for inflation. minemouth coal prices today are far lower than they were in the mid-to-late 1970 s when productivity bottomed out. These lower mine-mouth coal prices have allowed coal to generally remain competitive with oil and gas on a delivered basis to the electric utility markets, even after prices for these other fuels declined during the last few years (Figure 20).

The actual costs of mining coal vary greatly depending on the mine and mining method employed. Costs can be subdivided into three broad categories: capital, operating, and other costs. Capital costs primarily involve the costs incurred to open the mine (i.e., purchase of equipment and construction of facilities and roads) and the rate of return needed by the operator. Operating costs include labor wages and overhead, and equipment and supply costs. Capital and operating costs are interrelated and are principally a function of the coal geology, mining equipment to be used, labor wage scales, productivity, and regulatory rerjuirements. These in turn are affected by the coal reserves, the topography of the mine location, and the mine plan.

The third category consists of costs that are largely independent of production costs. This category includes public and private land costs and taxes. Included are royalty payments, federal and state income taxes, property and ad valorem taxes, severance taxes, and Federal black lung and mine reclamation fees. Some of these are a function of the tonnage produced, while others are tied to labor hours or minemouth prices.

Table 9 presents estimated mining costs for three representative types of coal mines: underground longwall operations, underground continuous miner operations, and large western surface operations. These mine types cover the majority of coal production. The individual cost components were collected and analyzed by the U.S. Bureau of Mines in 1989 based upon representative mines and using a discounted cash flow rate of return (DCFROR) methodology.t/

4) The financial analysis was make using the U.S. Bureau of Mines MINSIM/09 program. Source: Dept. of Commerce International Trade Administration and U.S. Bureau of Mines, A Cost Comparison of Selected U.S. and Australian Coal Mines, 1989. 


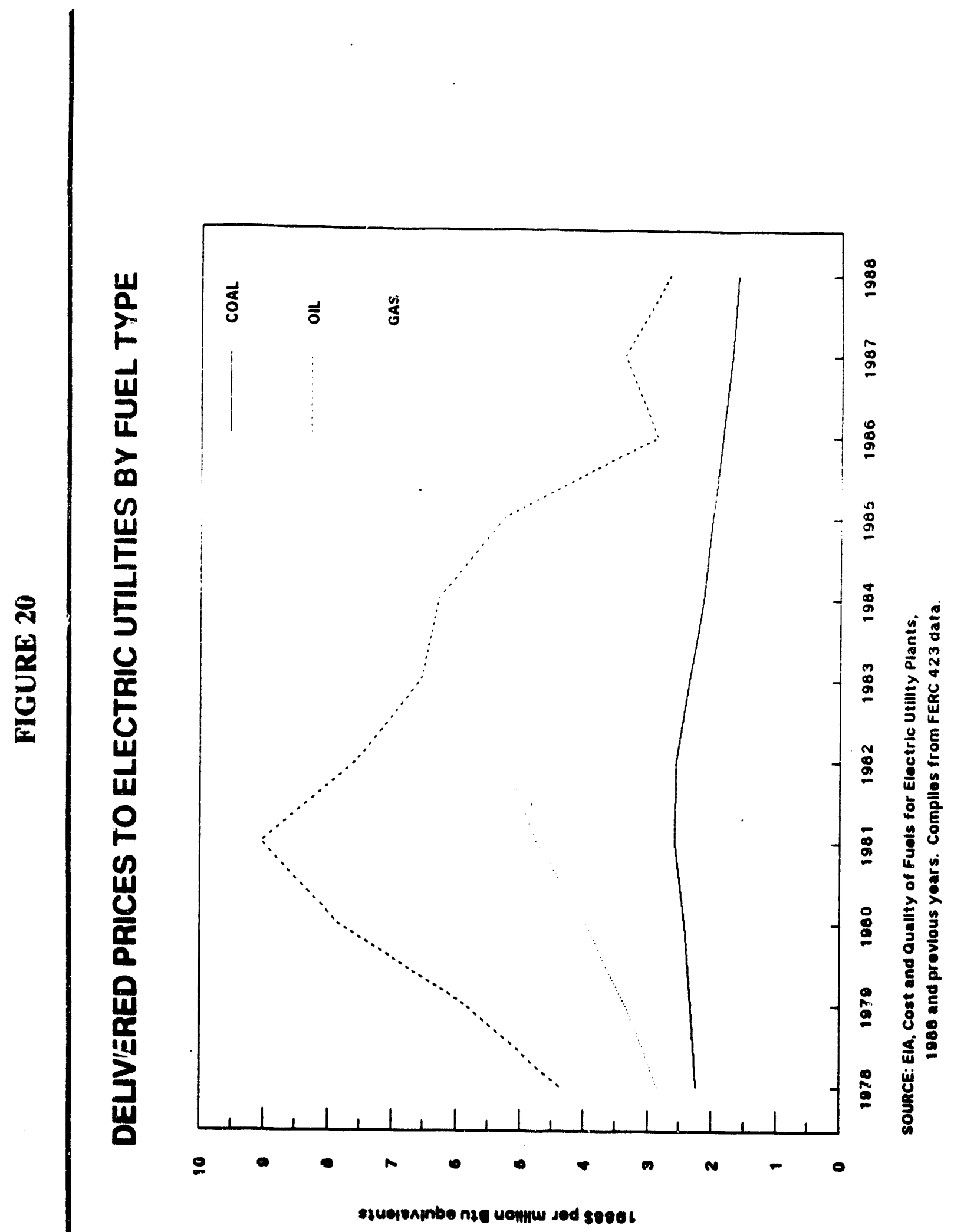


TABLE 9

Average Life-of-Mine Costs for Selected Types of U.S. Coal Mines

(in $1988 \$$ per short ton of raw coal)

\section{Cost Cateror}

At 15\% DCFROR:

Capital Costs"
Return of Equity Capital
$15 \%$ Return on Cash Flow
Mine Operating Cost2'
Labor
Equinment and Supplies
Other Costs:-
Royalties
Federal Income
State Income
Property and Ad Valorem
Severance and Excise Levy
Black Lung
Mine Reclamation

Total Cost $=$

\begin{tabular}{|c|c|c|}
\hline \multicolumn{2}{|c|}{ Eastem Underround } & \\
\hline $\begin{array}{l}\text { Large Longwall } \\
\text { Mine }\end{array}$ & $\begin{array}{l}\text { Large Continuous } \\
\text { Miner Mine }\end{array}$ & $\begin{array}{l}\text { Large Western } \\
\text { Surface Mine }\end{array}$ \\
\hline
\end{tabular}

\begin{tabular}{|c|c|c|}
\hline $\begin{array}{l}2.45 \cdot 4.00 \\
1.36-1.93 \\
0.53-2.18\end{array}$ & $\begin{array}{l}1.35-3.99 \\
0.56 \cdot 2.57 \\
0.62-1.43\end{array}$ & $\begin{array}{l}0.73 \cdot 0.96 \\
0.39 \cdot 0.60 \\
0.33 \cdot 0.36\end{array}$ \\
\hline $\begin{array}{l}9.06-15.71 \\
6.25 \cdot 9.21 \\
2.82-7.24\end{array}$ & $\begin{array}{c}10.95 \cdot 14.26 \\
6.73 \cdot 11.41 \\
2.85 \cdot 5.02\end{array}$ & $\begin{array}{l}\mathbf{2 . 5 9} \cdot \mathbf{3 . 1 1} \\
1.28 \cdot 1.65 \\
1.31 \cdot 1.61\end{array}$ \\
\hline $\begin{array}{l}1.50 \cdot 3.48 \\
0.00 \cdot 1.11 \\
0.36 \cdot 0.58 \\
0.06 \cdot 0.13 \\
0.02 \cdot 0.06 \\
0.18 \cdot 0.99 \\
0.56 \cdot 0.70 \\
0.08 \cdot 0.10\end{array}$ & $\begin{array}{l}0.97 \cdot 3.63 \\
0.04-1.56 \\
0.18 \cdot 0.42 \\
0.03-0.07 \\
0.01-0.09 \\
0.00 \cdot 0.81 \\
0.59-0.76 \\
0.08-0.11\end{array}$ & $\begin{array}{l}1.81 \cdot 2.55 \\
0.22 \cdot 0.71 \\
0.09 \cdot 0.10 \\
0.00 \cdot 0.02 \\
0.18 \cdot 0.33 \\
0.55 \cdot 0.93 \\
0.25 \cdot 0.27 \\
0.35 \cdot 0.35\end{array}$ \\
\hline $14.40 \cdot 22.03$ & $15.11 \cdot 20.89$ & $5.82 \cdot 6.25$ \\
\hline
\end{tabular}

$\underline{y} \quad$ Assumptions used in mine costing:

Annual Production, at Full Capacity

(Million clean tons)

Seam Thickness (feet)

Stripping Ratio

(cu. yds./raw ton)

Operating Days per Year

Overall Productivity".

(raw tons/person-hour)

Total Employment at

Full Production

Number of Shifts per Day
Large Longwall Mine
$1.1 \cdot 2.3$
$5.2 \cdot 7.2$

$238 \cdot 240$

$192 \cdot 240$

Large Continuous

Miner Mine

Large Western

Surface Mine

$3.5 \cdot 24.0$

$33.1 \cdot 74.2$

$3.6 \cdot 5.9$

$232 \cdot 360$

$3.6 \cdot 6.5$

$2.6 \cdot 5.5$

$14.3 \cdot 21.0$

$250 \cdot 670$

$120 \cdot 310$

$130 \cdot 260$

3

2- 3

3

- Includes all personnel aseociated with the operation of the mine and preparation plant including labor, supervision, and staff. Does not include any corporate or division overtead.

y Totals may not add because they represent the couts at an individual mine. Cost components within a column may be from several different mines to illuatrate the minimum or maximum value for each respective cout component.

Source: Department of Commence and U.S. Bureau of Minea, A Coot Comparien of Selected U.S. and Auturalian Mines, 1989. 


\section{ECONOMIC ACTIVITY}

\section{II.A GNP SHARE}

The coal industry represents less than one percent of the total U.S. GNP. During the 1980 s, the industry has generated annual revenues of between 25 and 35 billion dollars, adjusted to 1988 dollars. In 1988, the value of coal shipments totaled nearly 31 billion dollars. This came to about 0.6 percent of the 1988 GNP of over 4 trillion dollars. $-5 /$

The consumption of coal relative to the GNP has declined slightly since the beginning of the 1970s (Figure 21). In 1970, consumption of coal stood at about 4,500 Btu per GNP dollar (in 1988\$). By 1988, coal consumption had declined to 3,800 Btu per GNP dollar.

\section{II.B EMPLOYMENT}

In recent years, the number of workers employed in the coal industry has declined sharply. The 1988 workforce of 135,366 was less than were employed at any time since 1970 and significantly less than the 400,000 to 800,000 workers employed in the first half of this century (Figure 22). The drop in the coal mining workforce is due to increased labor productivity in both underground and surface mining, and to an increase in surface mining, which generally requires fewer employees. One surface miner, on average, will produce twice as much coal per hour as one underground miner.

Based on statistics complied on the 1986 workforce, firty two percent worked at underground operations, of which forty-six percent were in the mine and six percent at surface operations. Thirtyfour percent of the workforce were at surface mining operations. Of the remainder, nine percent were plant or mill workers and five percent were office workers.

The coal industry workforce as a whole ranks among America's most highly-trained, skilled, and best-paid industrial workers. A survey of the 1986 workforce indicates that in 1985 and 1986, workers underwent between 23 and 63 hours of training per year, including a mandatory 8 hours per year of health and safety training as required by MSHA. Amount of time in training generally increased at the higher levels with 63 hours being the average for working foreman. 6 /

Average annual income for coal miners in 1988 was about $\$ 35,000$ excluding overtime and bonuses. On an hourly basis, coal miners made $\$ 16$ per hour, about $\$ 2$ more than steel and auto workers, and about $\$ 4$ more than chemical workers. Other job benefits, such as health and welfare, are among the best in U.S. industry. ?/

5) Statistics generated using data from U.S. Industrial Outlook 1989 and Department of Commerce Bureau of Economic Statistics.

6) Butani, S.J. and Bartholomew, A.M., Characterization of the 1986 Coal Mining Workforce, BOM - IC 9192, 1988.

I) Nationa! Coa! Association, Con! Facts, 1989. 

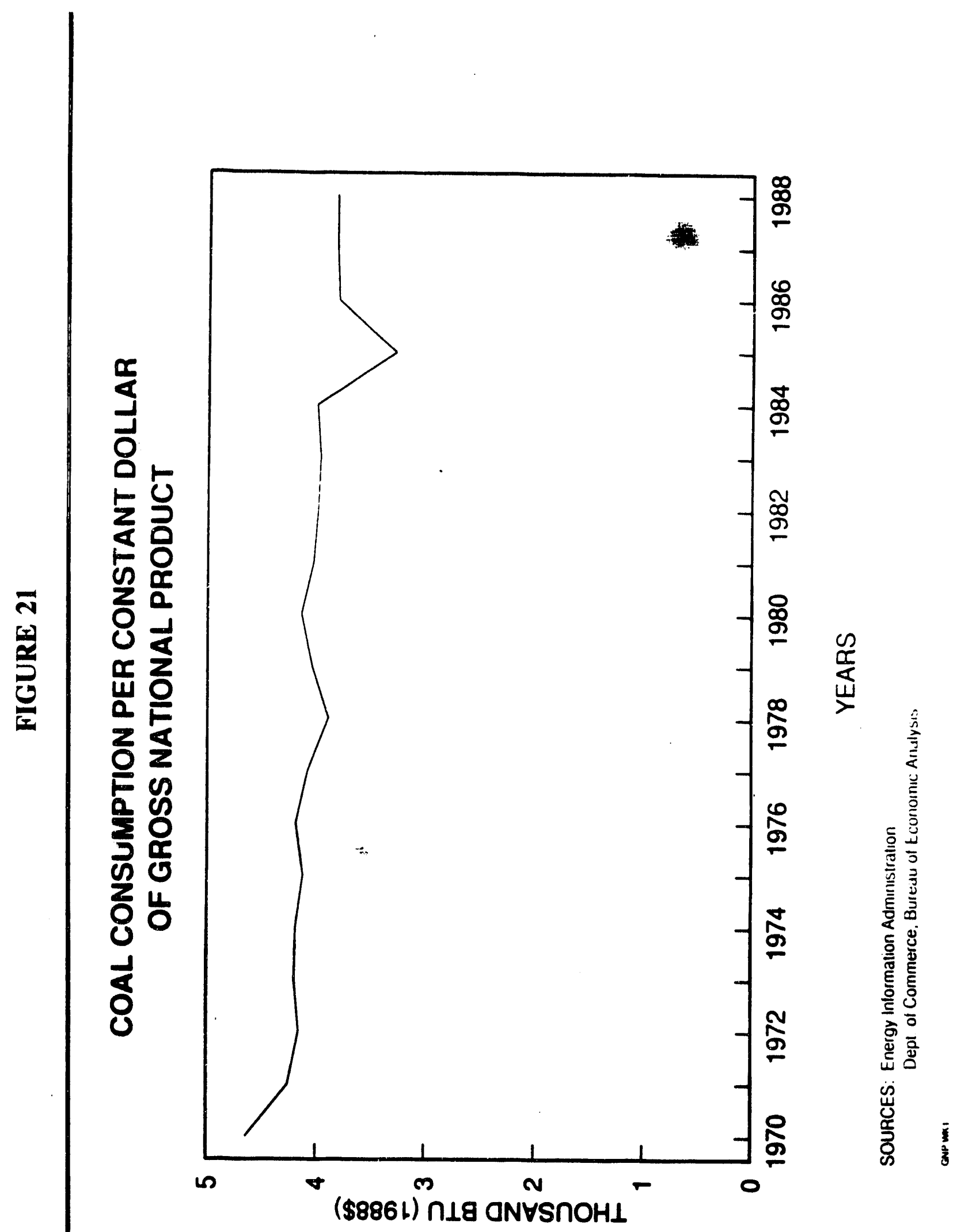


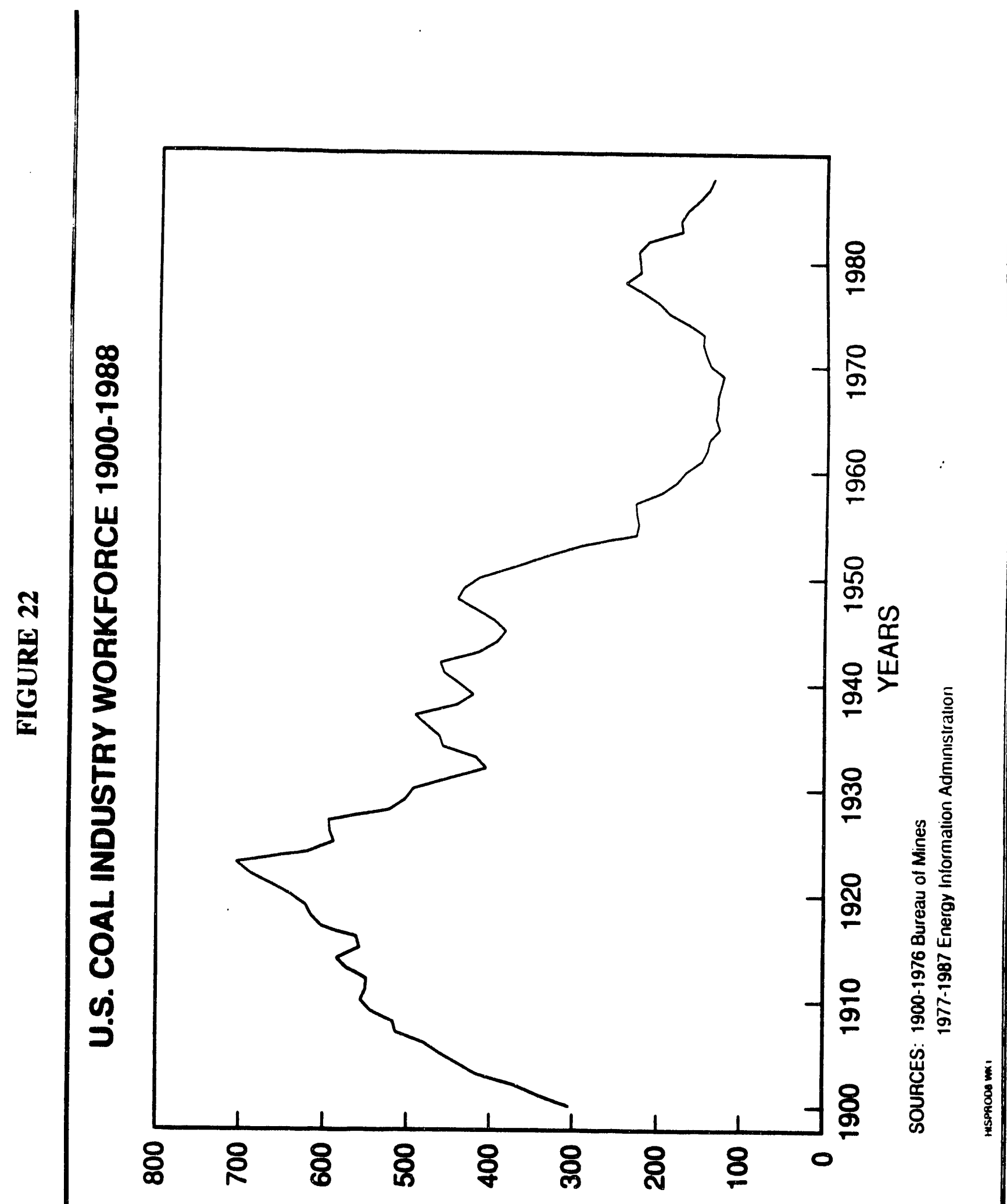

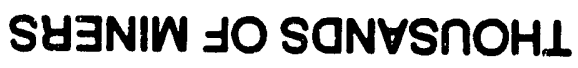


About 32 percent of the 1988 workforce were members of the United Mine Workers of America. 8/ This represents a substantial drop from UMWA representation in the 1970s. In 1972. $70 \%$ of the workforce was UMWA. This drop is in part due to the growth of coal production from western mines, which are largely non-union, as well as inroads made by non-union mines in the east. 9

Mining is still essentially a physical job, but as the industry's operations and equipment have become more technologically sophisticated in recent years, the type of person required has changed dramatically. The average worker today is older, averaging about 40 years old rather than 33 years old a decade ago, and better educated. Based upon 1986 statistics, 78 percent of the workers have a high school or better education.

A relatively recent development in the mining labor force has been the entry of women into the male-dominated production workforce. There are now almost 4,000 female miners in the workforce. They generally are slightly less experienced ( 95 percent have no more than 10 years of experience), and better educated with 87 percent of the women having at least a high school diploma compared to 77 percent of the men. In general, heavy machinery is still principally operated by male workers, but female workers are now represented in all equipment classes.

\section{II.C TRADE: IMPORTS/EXPORTS}

The United States exports coal to over 50 countries (Figure 23). Since 1980, annual coal exports of between 80 and 106 million tons have generated $\$ 3$ to $\$ 6$ billion annually, a significant positive contribution to the Nation's balance of trade. Canada remains the leading importer of U.S. coal. The U.S. also has significant markets in Europe and the Pacific Rim. Metallurgical coal exports represent nearly two-thirds of the exports. However, exports of coal to foreign electric utilities, cement plants, and other industries have risen with conversion from oil to coal spurred by oil prices rises in the 1970 s.

The level of coal exports is influenced by a number of factors. Changes in the economic conditions in the coal-importing countries, miner strikes and production interruptions in the supplying countries, price competition, and changes in the international exchange rates have all contributed to the prices foreign consumers are willing to pay for U.S. coal. Also, during the late 1970s and early 1980 s, countries with lower-cost reserves, such as Australia, Colombia, South Africa, and China penetrated the international coal market. The result has been that the United States is often a highcost supplier or on the margin. However, the U.S. has been able to maintain a significant share of the market for several reasons. Mainly these are the stability of U.S. coal supply, balance of trade and supply diversification considerations, and ocean freight advantages to some destinations (mainly in Europe).

\footnotetext{
8) National Coal Association, Coal Facts, 1989.

9) The RDI Market Watch, COAI, Aug. 1989.
} 

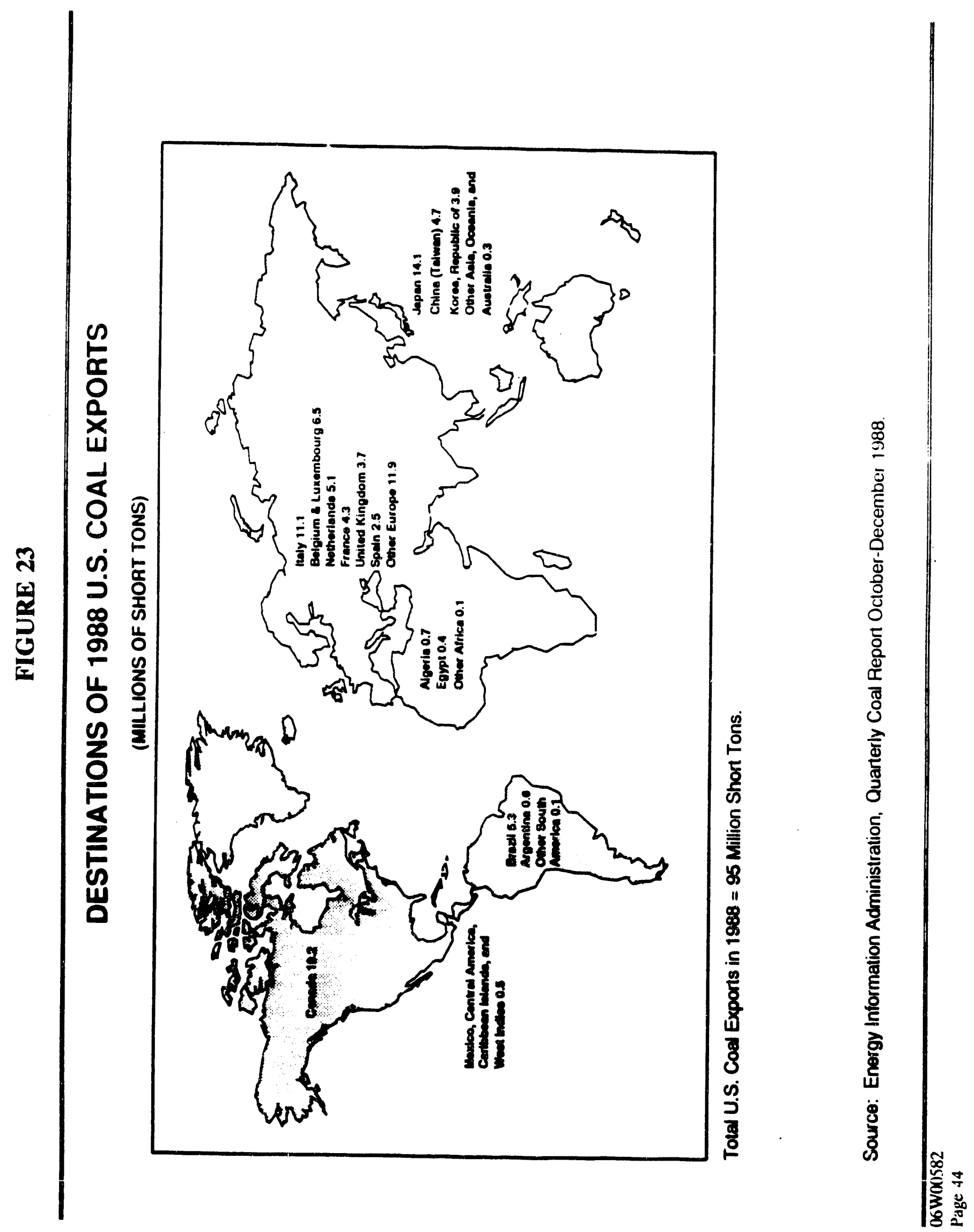
Coal imports, by contrast with exports, totaled less than 2 million tons in 1987 and were valued at $\$ 0.06$ billion. The coal was imported chiefly from Canada, Colombia, and Australia. Coal imported from Canada went primarily to areas of the U.S. not easily supplied by domestic sources. Colombian and Australian coal were purchased by southeastern utilities with power plants located on coastlines or near ports.

\section{II.D INVESTMENT ACTIVITY}

Investment activities of the U.S. coal industry intensified during the 1970 s in response to the increases in oil prices from the Arab oil embargo, shortages in natural gas, and economic forecasts showing huge increases in energy demand by the end of the century. Between 1973 and 1980. the industry invested an estimated $\$ 24$ billion into modernizing and expanding operations. $\underline{10}$ /

In the 1980s. lower oil prices and slower demand growth than had been torecasted combined to create overcapacity and an increasingly competitive environment in the coal mining industry. Fewer new mines were opened and capital investments concentrated on maintaining and extending existing equipment. Investments were also made to develop new mining technology aimed at increasing productivity and mine safety. $11 /$ On a yearly basis, capital expenditures decreased 30 percent between 1980 and 1987 (Figure 24). $\underline{12}^{\prime}$

In addition to investments made directly to mining coal, large amounts have gone to reclaiming old mining sites. Since 1978 , the industry has restored or reclaimed over 1.4 million acres of old mining sites and contributed more than $\$ 2$ billion to federal funds for abandoned mine reclamation. 13 /

10/ "Coal: Industrial America's Secret Success Story", Landmarc, p. 4-8, Jan./Feb. 1988.

11 "Coal: Industrial America's Secret Success Story", Landmarc, p. 4-8, Jan./Feb. 1988.

12J Gehman, John, "Surviving in a Competitive Market", Landmarc, p. 16-18, Jan./Feb. 1988.

13/ "Coal: Industrial America's Secret Success Story", Landmarc, p. 4=8, Jaa./Feb. 1988. 

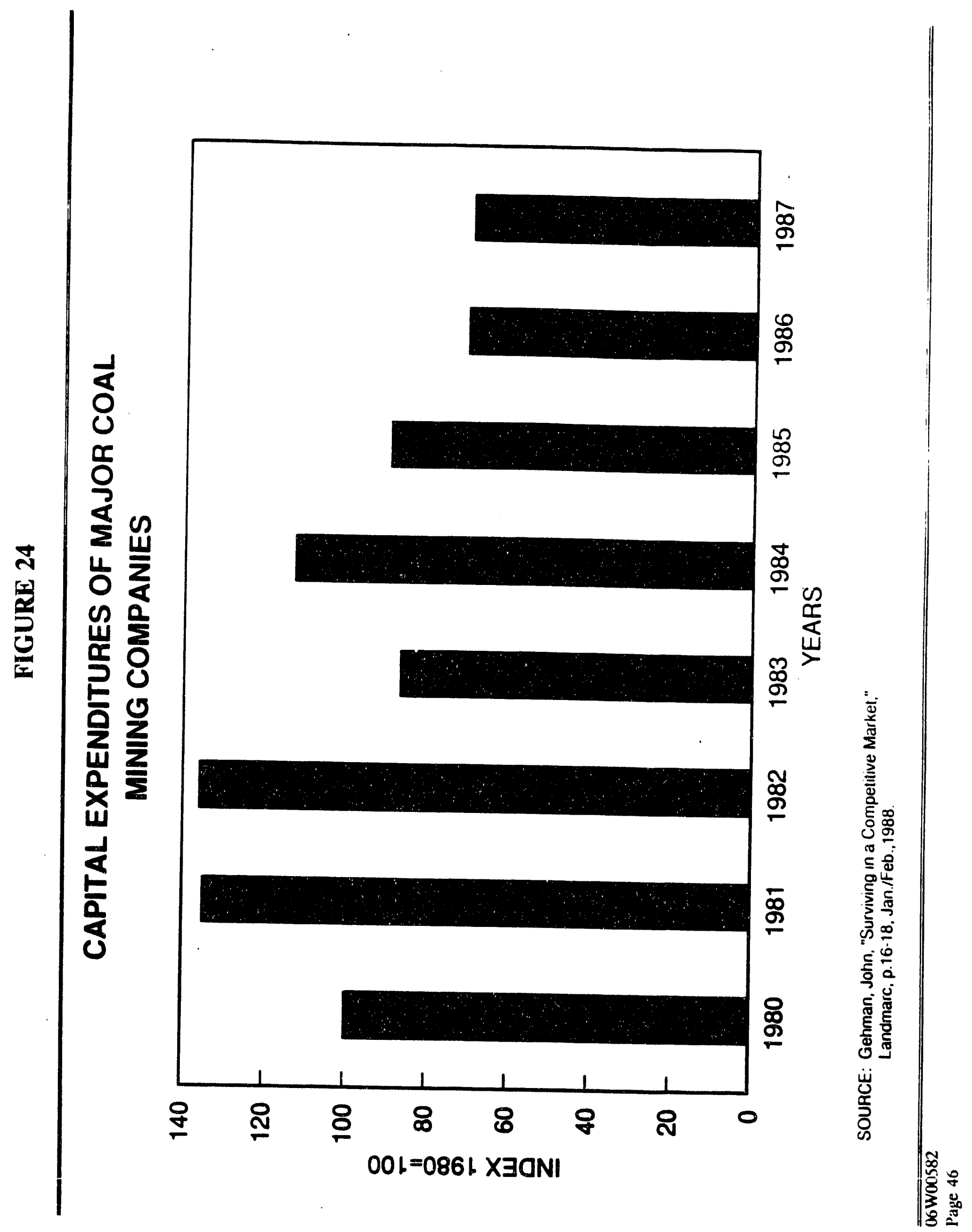


\section{SECTOR STRUCTURE}

\section{III.A INDUSTRY PROFILE}

Larger firms predominate in today's U.S. coal industry. Defined as those having annual production of at least 3 million tons, 51 "large tirms" in 1988 produced a total of 721 million tons, about $75 \%$ of total U.S. production. While coal mining remains one of our most competitive industries, the widespread restructuring of the past two decades has increased the share of the larger firms.

The present structure of the industry has its roots in the Arab oil embargo of 1973-1974 and in the natural gas shortages of the early 1970s. Anticipation of increasing oil prices, continued gas shortages and increasing demand for electricity created a focus on coal as the fuel of choice. Electric utilities, planning to meet future needs with coal-fired generation, sought long-term contracts with large suppliers or created coal mining subsidiaries.

Several oil and gas companies formed coal subsidiaries in order to take advantage of the anticipated demand growth. Some acquired existing coal companies, others grew via new mining ventures. By 1986, oil and gas companies produced nearly 44 percent of the total production by large firms (Table 10).

In the early 1980s, after oil prices had peaked, the increases in coal demand were slower than anticipated. Coal prices declined due partly to increased competition from oil and gas and partly to increased competition among coal suppliers. Declining demand from the industrial sector and a slump in the steel industry further tightened the market. Many older and/or higher-cost mines were closed and many small producers were forced to close or merge.

The number of mergers increased dramarically in the mid 1980s (Figure 25). While each transaction had a unique set of circumstances, several were driven by the desire of steel companies to divest most of their coal holdings and the desire of other companies to enhance their existing coal reserves, especially with low-sulfur reserves. In addition, many companies acquired coal properties from other companies or entered joint ventures. As a result of these activities, the top 15 coal producing companies in 1987 are a very different group than the top producers in earlier years, many having only recently appeared on the list (Table 11 ).

The coal industry has been increasing in international scope, and foreign investment in the industry has risen. Foreign-affiliation is defined by the Department of Commerce as ownership of more than 10 percent of the voting securities by a foreign direct investor. Foreign-affiliated coal producers' share of U.S. coal production stood at 16.4 percent in 1986, up from 4 percent in 1980. If only foreign-controlled firms were considered (those with more than 50 percent ownership) the percent of 1986 production by foreign companies would be only 6.4 percent.

The international scope of the coal industry involves not only foreign involvement in U.S. firms but vice versa. Several U.S. firms participate in foreign production. A notable example is Exxon's joint venture to develop Colombia's El Cerrejon mine. Exxon also owns a large surface mine in British Columbia. Occidental Petroleum Corp. has a joint venture agreement at China's An Tai Bao mine. ARCO has an interest in two Australian mines and an option on a third. ARCO also has a joint venture agreement to produce low-sulfur coal in Venezuela. Mobil Oil is developing reserves in Indonesia and Cyprus Mininerais is starting development of its Âstraiia reserves. 

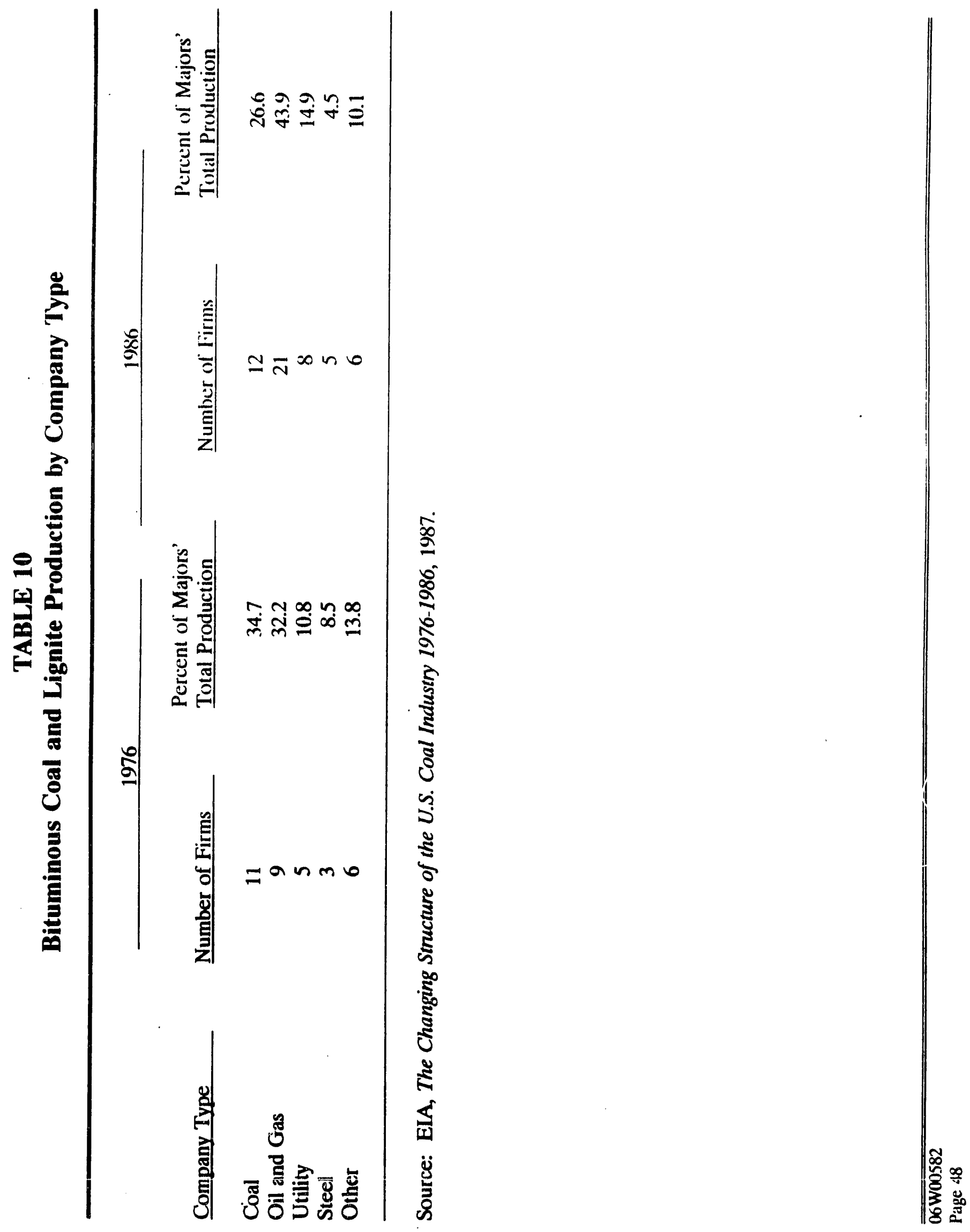


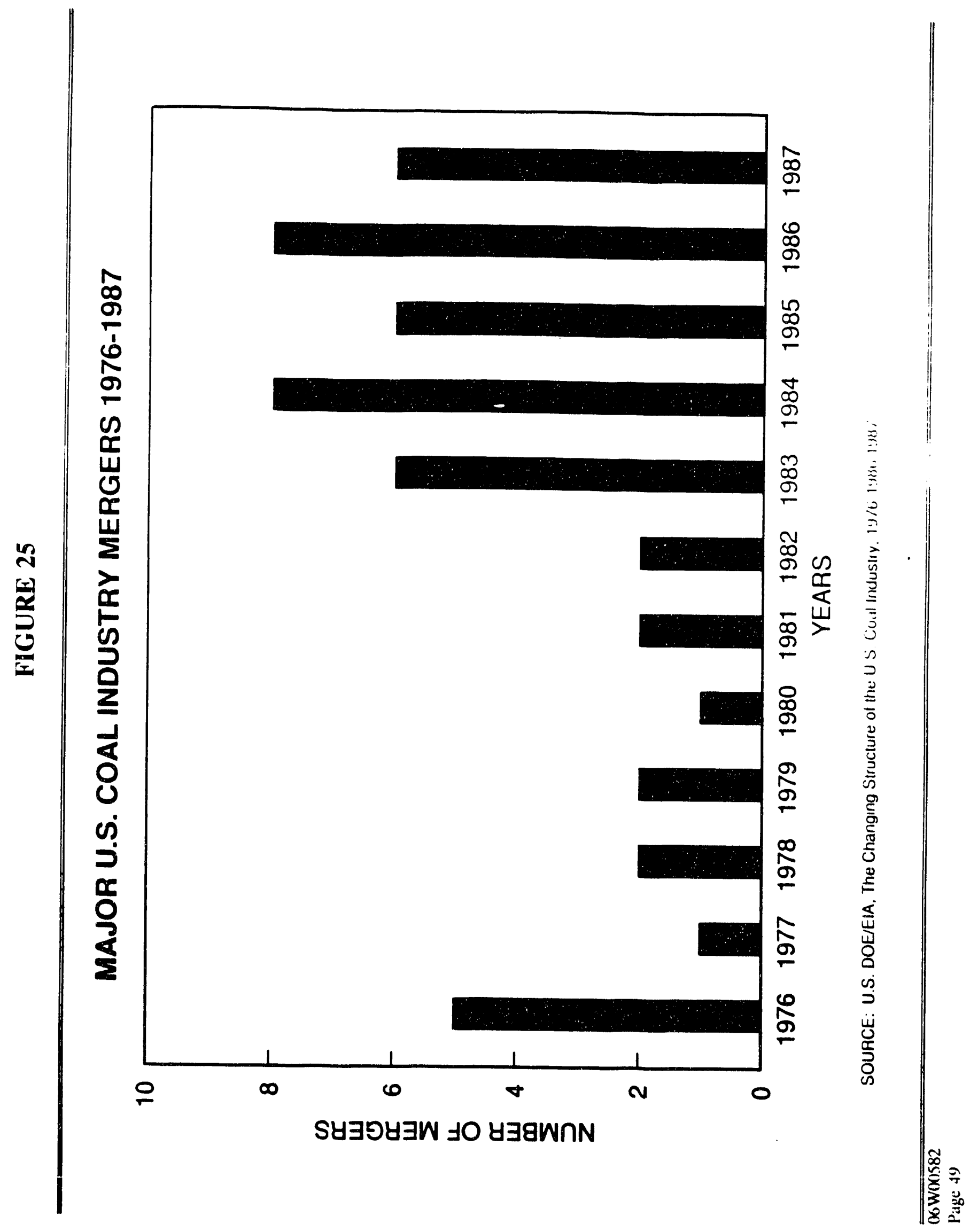




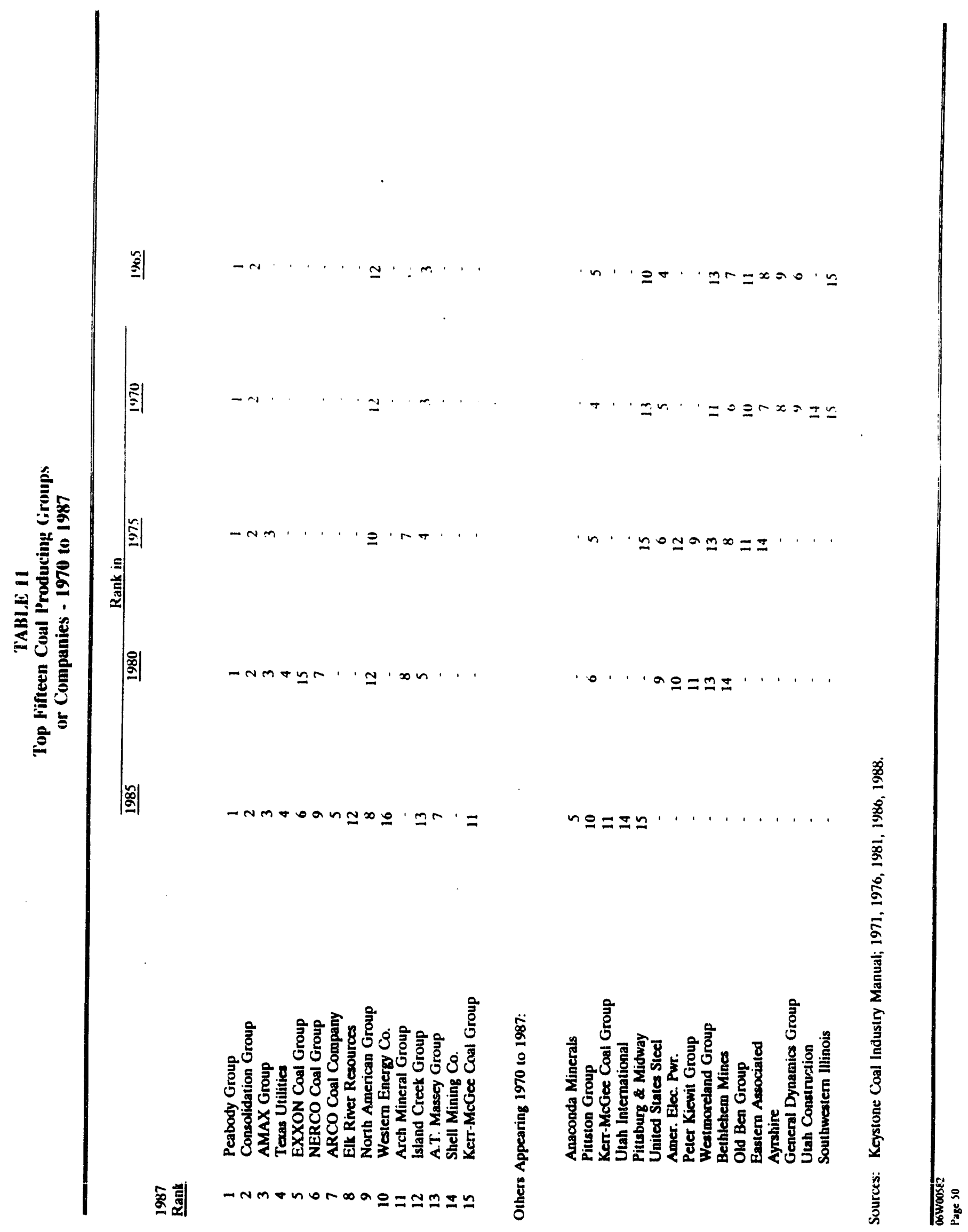




\section{III.B COAL TRANSPORTATION}

Since coal reserves are often located far from their markets, the coal industry depends heavily on the transportation network for delivering coal to customers across the country and abroad. The tlow of coal is accomplished by railroads, barges, ships, trucks, conveyors, and slurry pipeline. Frequently, coal deliveries are handled by more than one mode of transportation before tinally reaching the consumer.

As a solid bulk fuel. coal typically incurs significant transportation costs in reaching its end-use markets. As a percentage of total delivered price, transportation of coal accounts for a larger share than does transportation of oil or gas (Figure 26). For some coal movements. Powder River Basin coals in particular. transportation costs are greater than mine-mouth prices.

Transportation modes vary regionally. In much of the western U.S. where navigable waterways are lew and consumers are often located far from the coal sources. rail is the only feasible means of originating coal for long distance transport. In much of the eastern U.S. trucks and or barges often provide competitive alternatives to rail transport (Figure 27).

\section{III.B.1 Railroads}

Railroads are the dominant mode for transporting coal. In 1988, railroads originated $58 \% c$ of the coal delivered to U.S. destinations, and originated an even higher percentage of the coal shipped to foreign consumers. In turn, coal shipments are the major commodity moved by railroads and a major source of revenue. In 1987 coal accounted for 38 percent of the freight carried by Class I railroads and 22 percent of their revenues.

The railroad industry was in substantial decline from World War II through the 1970s. During the 1970s, many railroads went bankrupt, and the ultimate viability of our Nation's rail system was in doubt. In response, Congress in 1980 passed the Staggers Rail Act to partially deregulate rail rates. Railroads were given more freedom to set rates, reduce costs, and enter into contracts with shippers. The purpose of the Staggers Rail Act was to create a more flexible environment which would permit railroads to improve their earnings. It was generally acknowledged that this lack of earnings had created conditions under which railroads couldn't buy sufficient new equipment and couldn't improve or maintain track and equipment for more efficient operations.

There were widespread expectations at the time of passage that many coal users could face sharply higher rail rates. However, by placing reliance on the marketplace to set most rates, those expectations have generally not materialized. Rail rates, adjusted for inflation, have in fact fallen significantly since the Staggers Rail Act was passed. In contrast, rail rates and costs for coal had risen substantially before passage of the Act (Figure 28).

The operational and financial conditions of the U.S. railroad system have improved markedly in the 1980s following passage of the Staggers Rail Act. The rail system is being streamlined, with unprotitable tracks being abandoned or sold off. Railroad operations have improved, productivity is up, most rates are steady or declining, and railroad firancial conditions have improved. For the first time since the Staggers Rail Act, two railroads met the ICC's standards for "revenue adequacy" in 1988, and several others are reporting improvements in financial returns. 


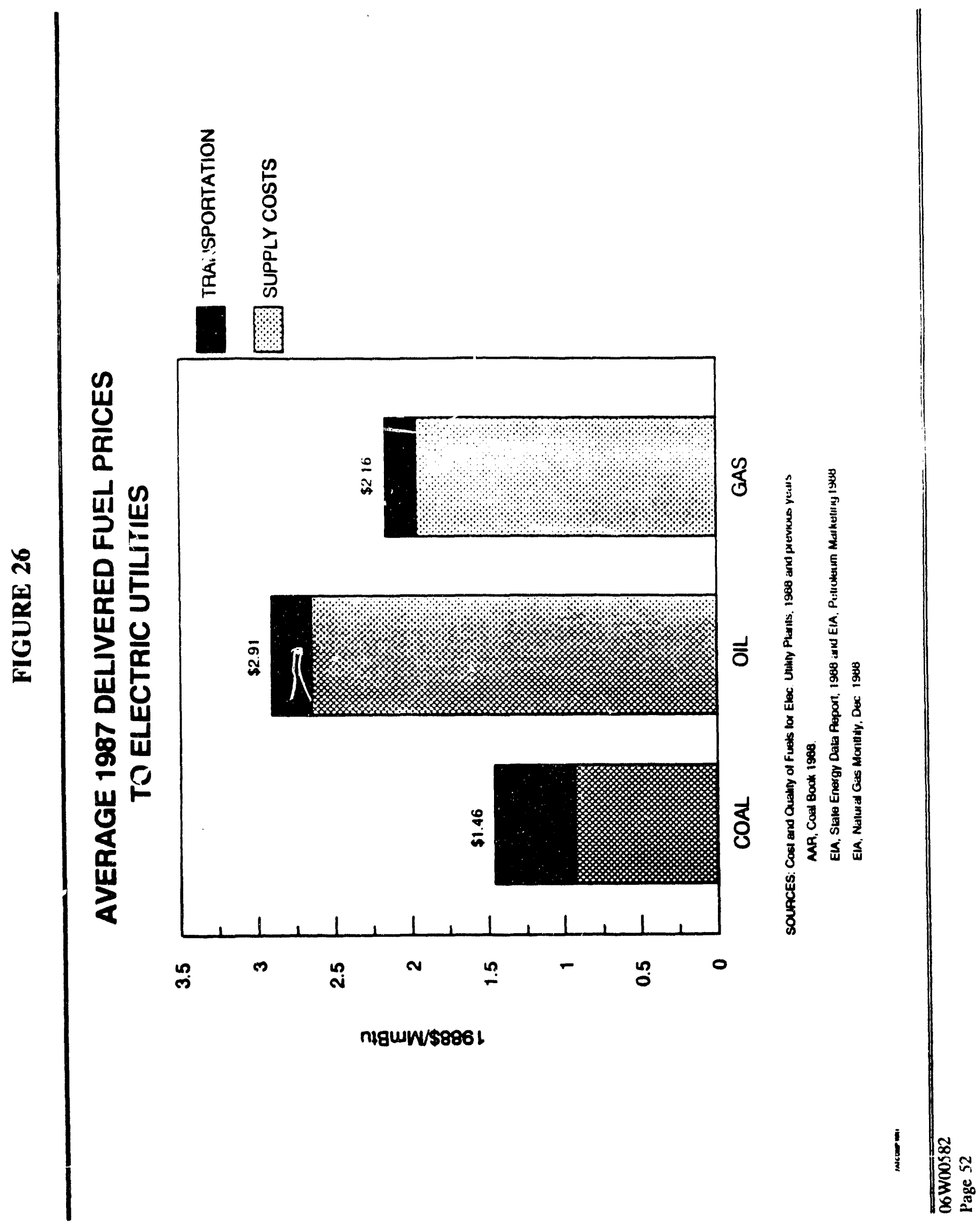




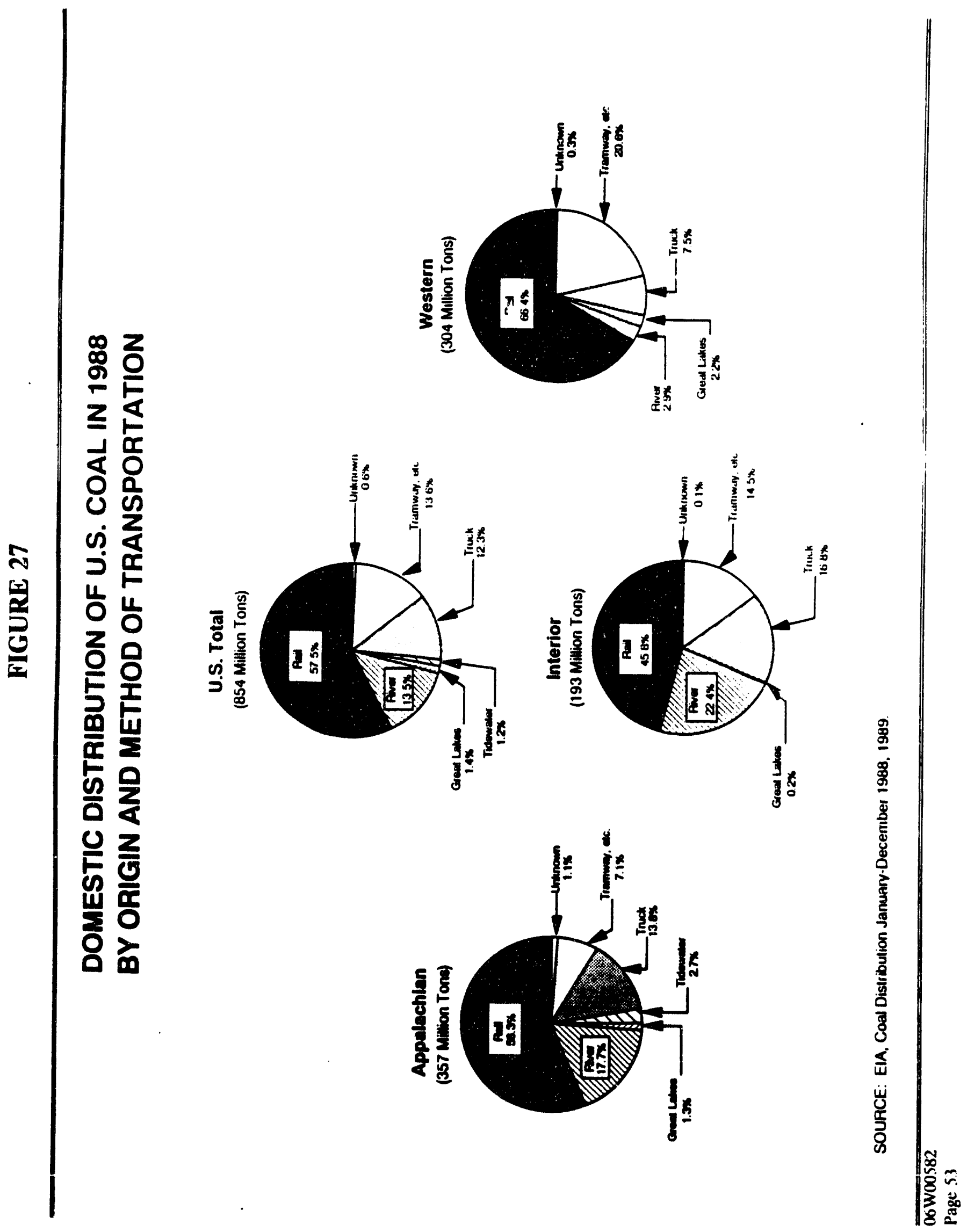




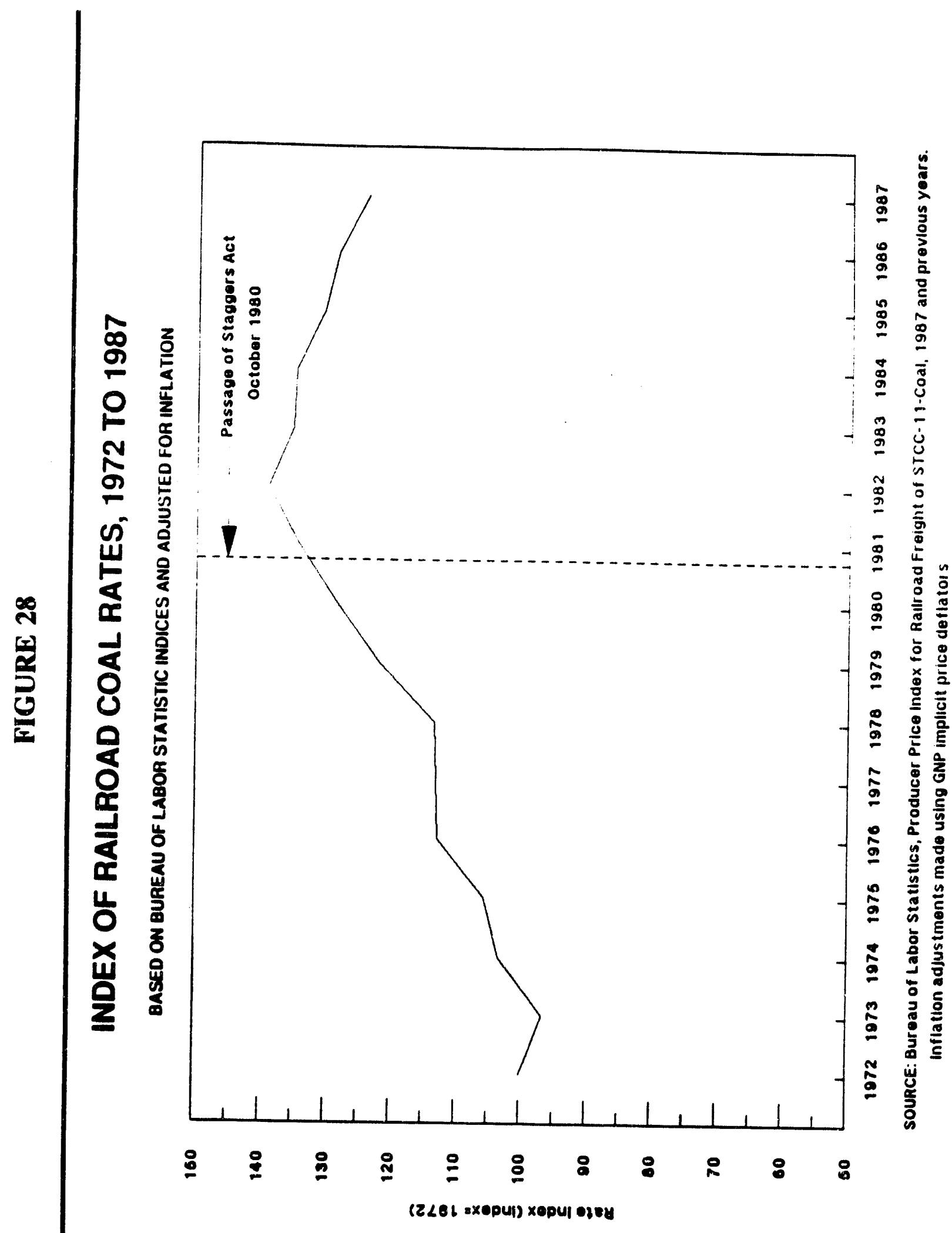

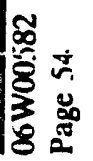


The railroad industry has undergone a tremendous consolidation. In 1976, there were 50 Class I railroads hauling coal. By 1987, there were just 18 coal-hauling Class I railroads, originating a total of 523 million tons of coal. Three of these railroad systems (CSX Corporation, Burlington Northern, and Norfolk Southern) collectively originated over 400 million tons of coal. While this consolidation has played a key role in improving railroad efficiency and financial performance, many shippers are concerned about being "captive shippers" and are therefore vulnerable to potential railroad market power.

\section{III.B.2 Waterborne Transportation}

Waterborne coal shipments rank next to railroads in tonnage, accounting for around one-sixth of the coal shipped. In the Appalachian and Interior regions, waterborne shipments comprise more than 20 percent of the movements, while western waterborne movements are much less.

Barges are used to move coal on rivers, chiefly on the Mississippi River and its navigable tributaries such as the Ohio and the Monongahela Rivers. Bulk carriers are used on the Great Lakes and in tidewater areas to move coal both domestically and to Canada. On the Great Lakes. cual traffic generally ranks second only to iron ore. The most extensive coal traffic on the lakes is upwards to destinations in the north and west. Traffic downwards generally contains iron ore or grain. Shipping on the Great Lakes usually is immobilized by ice from mid-December through midMarch.

\section{III.B.3 Truck}

Coal deliveries by truck are generally used for short hauls and make up over 10 percent of coal shipments. Truck hauls are generally less than 50 miles and seldom more than 100 miles. In many areas of mountainous terrain and/or where rail infrastructure is absent, trucks are the only viable means to ship coal. Trucks also play an important role in many multi-mode shipments, originating or delivering coal in connection with rail or water movements.

\section{III.B.4 Tramways and conveyors}

Most of the remaining coal shipments are made by aerial tramways and conveyors. Aerial tramways cover relatively short distances, but conveyors can be several miles. Both commonly link mines with minemouth electricity generating stations.

\section{III.B.5 Coal Slurry Pipelines}

Coal slurry pipelines have been identified by some coal producers and shippers as having potential as an alternative to rail shipments of coal. At present there is one operating coal slurry pipeline in the U.S. All other proposed slurry projects are either on hold or have been terminated due to difficulties in implementing them.

Coal slurry pipelines are similar to those used by the petroleum and natural gas industries They are designed for transporting pulverized coal in a medium such as water, oil, coal-derived methanol, liquified carbon dioxide, and salt water. At present, only coal-water slurries have been used commercially. 
Three major stages are involved in moving coal by pipeline: processing, transmission, and dewatering. In processing, the coal is crushed and mixed with the slurry medium. The optimal particle size and ratio of coal to slurry medium depends on each pipeline's design and application. Transmission involves the feeding of the slurry into a buried steel pipe and propulsion by pumps located at 50 to 150 mile intervals. The slurry moves through the pipeline at speeds between 5 to 6 feet per second. Slurries can be batched for shipment according to specifications and destination. At the pipeline terminus, the coal is removed from the media by settling, vacuum filtration. or centrifuging, and then flocculation (a chemical process for settling the suspended particles while removing the cleared slurry medium). After the coal slurry has been dried. it can be stored. transported further, or ground at the delivery site for used in coal-tïred boilers.

Only one coal slurry pipeline is presently in operation. 'This pipeline, the Black Mesa pipeline. began operations in 1970 and carries a slurry composed of finely ground coal and water. The pipeline originates at the Black Mesa mine in northern Arizona and extends 273 miles to the Mohave power plan in southern Nevada. The pipeline carries about 4 million tons of coal per year.

\section{III.C PERIPHERAL INDUSTRIES}

Peripheral industries principally involve equipment suppliers. These can be subdivided into two general groups: suppliers of mining preparation, storage and loading equipment, and suppliers of coal quality analysis equipment and services.

The U.S. mine machinery industry supplies coal mining equipment and replacement parts. The industry supplies not only the machinery used to extract the coal but also those associated with all activities at the mine site. These include:

- Haulage Equipment - These are systems used to transport the coal from the coal face to the minemouth and from the minemouth to either the preparation, storage, or loading facility. Systems used include conveyors, rail, and trucking.

- Coal Preparation Equipment - Coal mines typically have at least breakers and crushers. In addition, systems are available to clean impurities from coarse lumps to coal particles as fine as dust.

- Mine Safety Equipment - Rock dusting and ventilation systems are required for all underground mines. They are installed to control coal dust and methane emissions.

- Coal Storage and Loading Equipment - These include equipment to store, reclaim, and load the coal for shipment.

U.S. mining machinery is also traded internationally. In 1988 , the U.S. exported about $\$ 300$ million and imported almost an equal amount ( $\$ 240$ million). These included both coal mining equipment and equipment for other mining industries. The primary foreign markets for U.S. mining machinery are Canada, Mexico, Turkey, Australia, China, and Colombia. Other than the United States, the main supplier countries are the United Kingdom, West Germany, Canada, and Japan. 
The other major peripheral industry group involves the analyses of coal to determine if it meets the contract specifications of the customer. All coal must be analyzed and these analyses are required by both the suppliers and most consumers. Analytic services can be purchased by either party. Typically, coal analyses are done by automatic sampling and testing equipment located at the mine site, or by shipping samples to laboratories specializing in coal analyses. 


\section{FUEL CYCLE CHARACTERIZATION AND COSTS}

The coal fuel cycle has four primary steps from the time coal is extracted from the ground to when it is consumed: mining, preparation, transportation, and utilization. Coal mining extracts the coal trom the ground. using either underground mining techniques or surface mining techniques. After the coal is removed from the ground it undergoes preparation, ranging from simple crushing and sizing to more extensive preparation to remove excess sulfur or ash. The coal is then transported to the customer using railroads, inland waterways, trucks, tramways, conveyors or slurry pipelines. The last step of the fuel cycle consists of either the burning of coal, principally by electric power plants or industrial boilers. or the conversion of the coal into coke to be used in the steel making process.

The solid wastes generated by coal mining, preparation, and utilization are mostly disposed of in landfills or sediment ponds. Emissions occurring during the burning of coal are controlled to stay within Federal and State limits. The following sections contain more detailed discussion of the various steps of the coal fuel cycle. Where practicable, approximate costs are included.

\section{IV.A COAL MINING}

Coal is mined by either underground or surface methods depending mostly on the depth of the coal seam. Those that are deeper than 200 feet are generally mined by underground techniques. Shallower seams are usually mined by surface methods. However some Eastern mines having depths of less than 200 feet are mined by underground methods due to topographic and geologic factors.

\section{IV.A.1 Underground Mining}

Underground mines are accessed by one of three types of entries: drift, slope, and shaft. (Figure 29). Drift entries are accessed through a horizontal opening dug into a hillside. Slope entries are inclined openings dug to the coal seam. Shaft entries, equipped with elevators, are vertical accesses to coal seams which are generally deeper than can be reached by either of the other methods.

Once the coal seam is reached, it is sectioned into panels or blocks, typically several hundred feet wide and several thousand feet long (Figure 30). Then the coal is removed using either the room-and-pillar, longwall, or shortwall methods.

Most underground mines in the U.S. use the room-and-pillar method. In this method, the coal seam is mined by carving out a series of rooms, generally 20 to 30 feet wide, in the panel. A series of pillars is left to support the mine roof. When the end of the panel is reached, the mining direction is usually reversed, removing as many of the pillars as possible during the process. Only 5060 percent of the coal can be removed using room and pillar techniques. The remaining coal must be left in the ground as roof supports. 


\section{FIGURE 29}

\section{TYPES OF ENTRY FOR UNDERGROUND MINES}

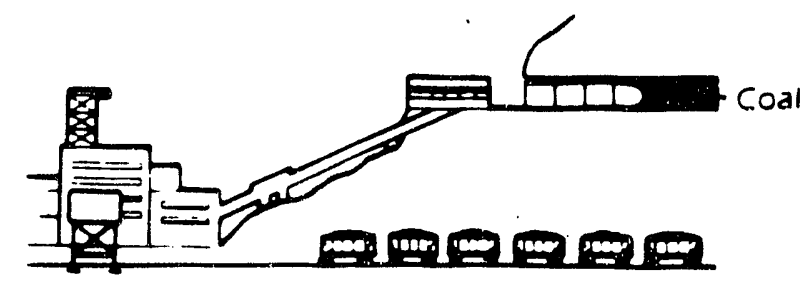

DRIFT MINE

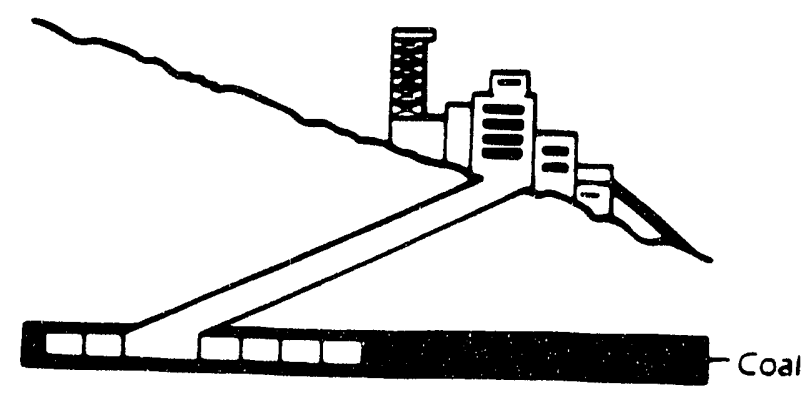

SLOPE MINE

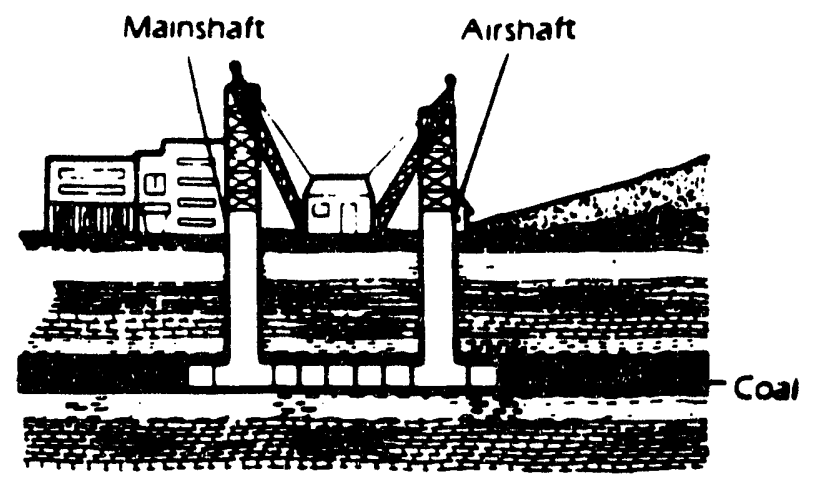

SHAFT MINE

FROM: ELA, Cos Data, A Reference, 1969 


\section{UNDERGROUND MINING METHODS}

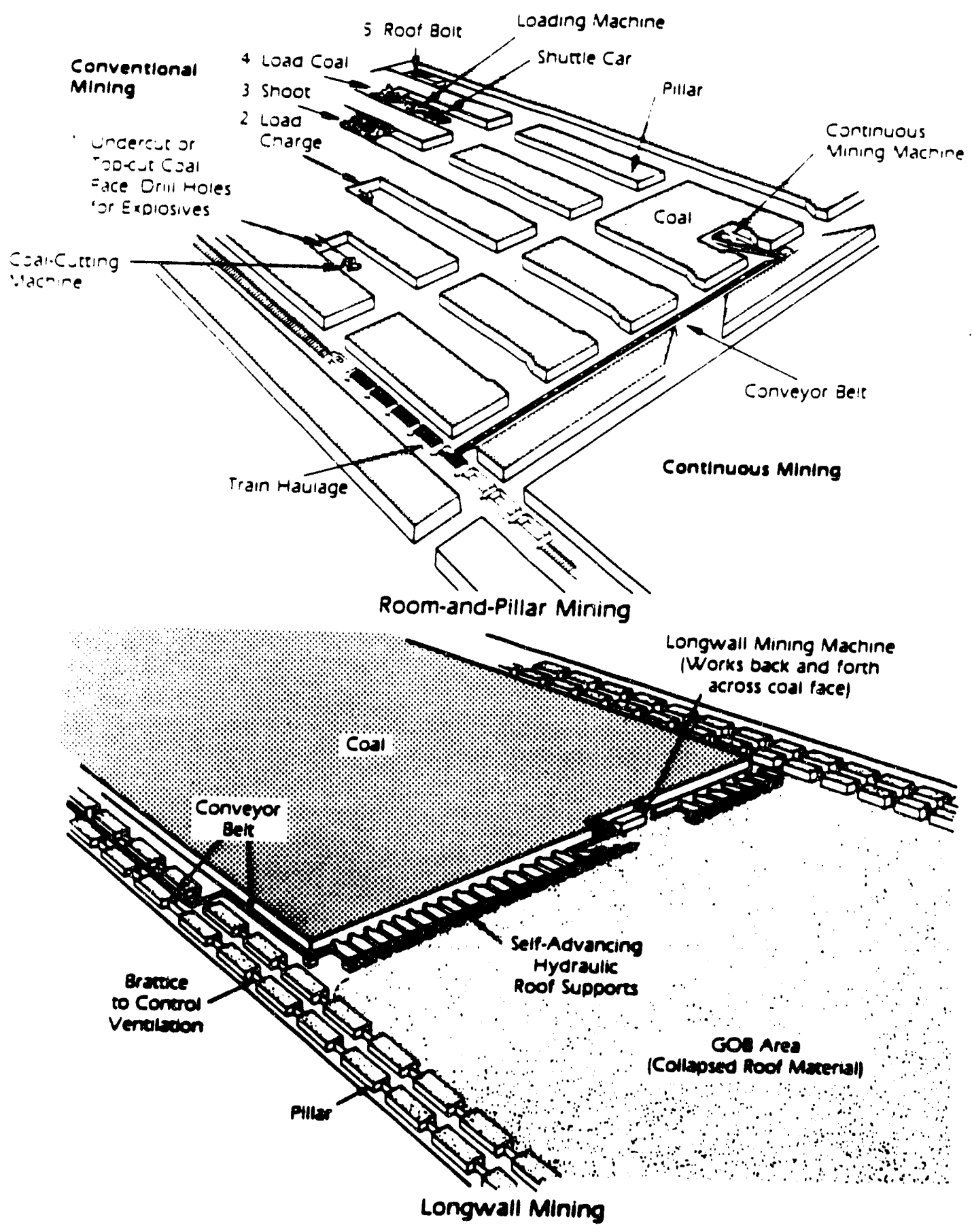

FROM: EIA, Coel Dats. A Reterence. 1900 
Three techniques used in room-and-pillar mining are hand-cut, conventional, and continuous mining. In hand-cutting, the coal is undercut, blasted from the face, and then hand loaded onto shuttle cars. This method has been almost completely replaced in the U.S. by conventional and continuous mining which mechanizes the process. In conventional mining, separate machines are used to cut, drill, and load the coal. Continuous mining uses a continuous miner machine that combines cutting. drilling, and loading coal in one operation. This technique doesn't require blasting, thereby greatly increasing the safety of the mining operation.

Another common underground mining method is longwall mining. It presently accounts for about one-third of the underground coal mined. This method uses a cutting machine, installed under movable roof supports that are advanced as the bed is cut. The roof in the mined-out area is then allowed to fall in. Two types of cutting machines are used, plows and shearers. A plow is blade-like and fitted with bits or a saw-tooth edge that cuts the coal face into slices. A shearer, the most commonly used machine, has one or two drums fitted with bits and cuts up to 36 inches of coal trom the face with each pass. The shearer also cuts the coal into chunks of approximately two inches, essentially eliminating the crushing and breaking step of coal preparation.

Productivity at longwall mines is up to five times that of room-and-pillar mines. In addition. longwall mines can recover up to 80 percent of the coal in place. However, the longwall mining technique is limited in application since it is not suitable if the thickness or inclination of the coal seam varies excessively.

In a. few cases in the U.S., a shortwall technique has been adopted where continuous miner machines are used under movable roof supports. The panels of coal mined are usually narrower and shorter, th this method allows greater flexibility due to the smaller working area.

\section{IV.A.2 'jurface Mining}

At shallow depths, surface mining is generally the least expensive, safest, and most efficient method of mining coal. Surface mining essentially involves large-scale earth moving operations where the overburden (rock and soil above the coal seam) is removed, the coal is extracted, and then the overburden is returned to the pit during reclamation. Coal recovery rates are typically 80 percent in Eastern mines and 90 percent or more in Western mines.

The productivity and costs of surface mining are principally a function of the amount of overburden (in cubic yards) that must be excavated per ton of coal, often called the overburden ratio. The lower the ratio, the more productive and less costly the coal is to mine. In general, western surface mines, especially those in the Powder River Basin, have the lowest overburden ratios (many are less than 2:1 cubic yards per ton of coal). Eastern mines usually have higher overburden ratios of $15: 1$ or greater.

There are three main methods of surface mining: strip mining, open-pit, and contour mining. Strip mining is done on flat or gently rolling terrains using a large excavation machine called a dragline. The dragline has a large bucket suspended from the end of a high boom by a series of cables. It is capable of scooping up huge amounts of overburden as the bucket is dragged across the excavation area. In strip mining, the overburden is removed in long strips with the material excavated from one strip redeposited in the previously mined-out area (Figure 31). 


\section{FIGURE 31}

\section{SURFACE MINING METHODS}

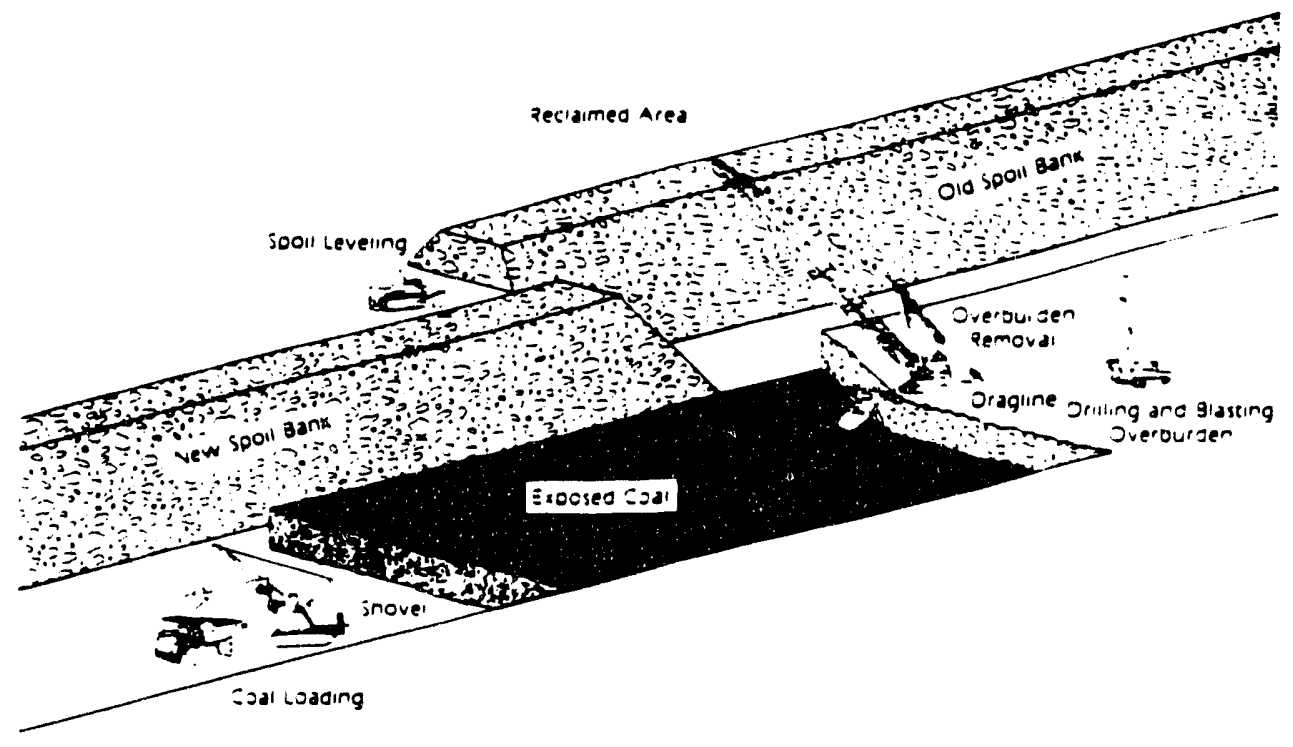

STRIP MINING "

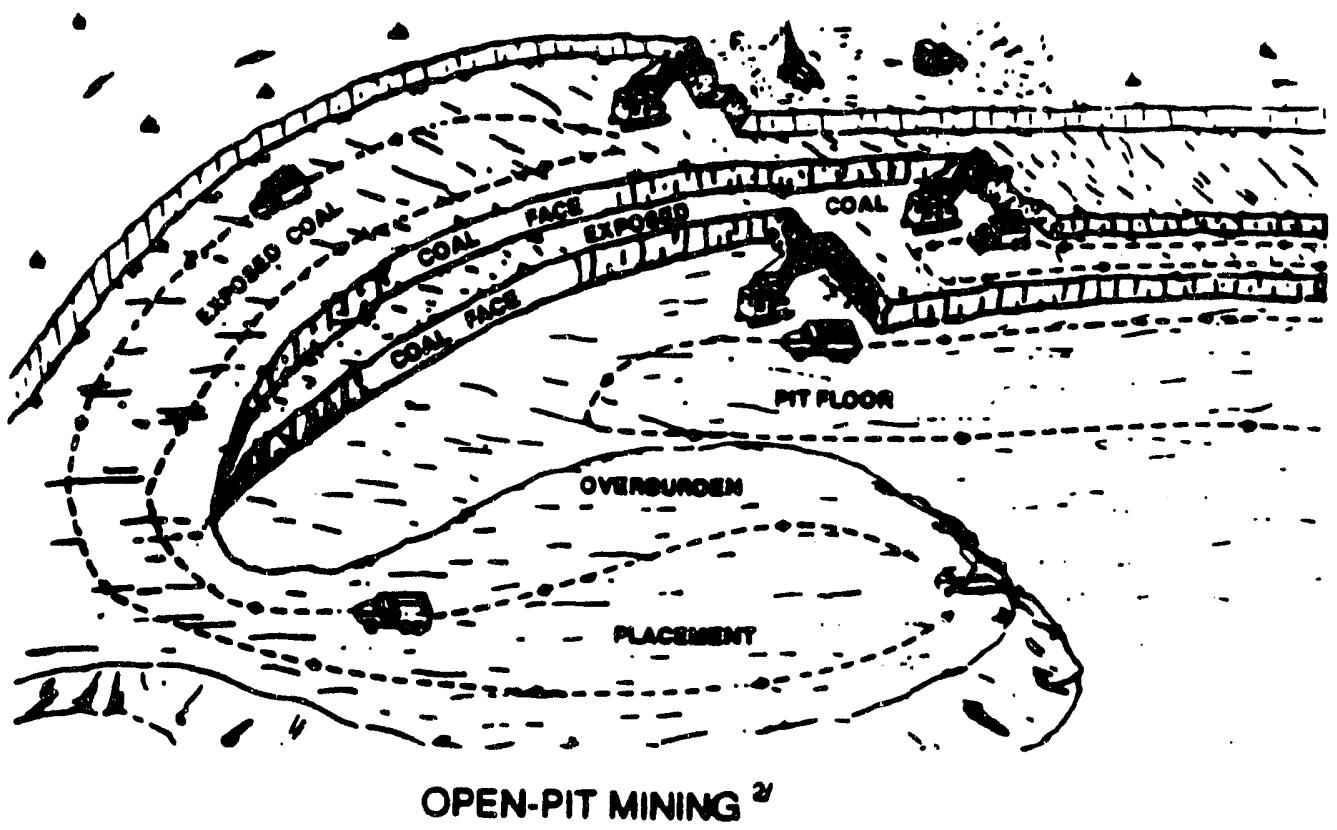

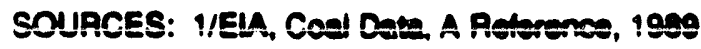

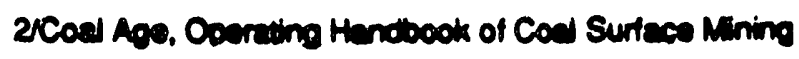
and Rectumion. 107 
Open-pit mining is often used when overburden and/or coal seam thicknesses are too great for the dragline to handle in one pass, or when the terrain is steeply inclined. In this method, blocks are cut down to the coal, essentially creating a hole or open pit. Power shovels and trucks are used to excavate both the overburden and the coal. As the coal is removed, the overburden is returned to the mined-out portions which are then reclaimed (Figure 31 ).

In some of the larger western open-pit mines, a combination of draglines and shovels is used to remove the overburden. The draglines are used to do the initial stripping of the overburden after which the shovels are used to finish the overburden removal and mine the coal.

Contour mining is done mostly in the eastern U.S. where surface mines are located in hilly and mountainous terrain. This method of surface mining makes an initial cut in a hillside at a point where the coal outcrops. Successive cuts are then made into and around the hillside until it is no long economically feasible to remove the overburden. At this point, augers may be used to drill 100 feet or more into the coal bed or a small drift mine may be opened to produce the more deeply buried coal.

\section{IV.B PREPARATION}

Most coal undergoes some form of processing before it is loaded for transportation. Coal cleaning comprises the following basic steps (Figure 32): 1) crushing and/or breaking; 2) sizing both to meet the market requirements and to match the specifications of the various cleaning devices if the coal is to undergo further preparation; 3 ) washing to remove impurities from the coal; and 4) dewatering and drying to remove excess moisture and prepare the cleaned coal for shipment. In addition, different coals can be blended to create a product suitable to the customer's requirements. For example, a high-sulfur coal may be blended with a lower sulfur coal to produce a sulfur level acceptable to the customer. Also, coking operations often use coal blends from several sources to meet tight specification for coal quality and consistency.

The amount of preparation required depends on the customer's specifications. Nearly all coal, at a minimum, undergoes crushing, breaking, and sizing. About two-thirds of the coal mined in the East for electric power plants is cleaned, whereas most of the western coal is shipped after only being crushed and screened to remove extraneous material. Nearly all coal used to make coke for steelmaking undergoes a high level of cleaning.

Cleaning upgrades the quality and heating value of coal by removing or reducing the amount of non-organic sulfur, rock, clay, and other ash-producing material, as well as material that became mixed in during mining, such as wire and wood. Most coal cleaning is based on the principle that coal is lighter than rock and other impurities mixed or embedded in it. The rock and impurities are removed by various mechanical devices using pulsating water currents, rapidly spinning water (centrifuging), and liquids of different densities (heavy media). Finely sized coal can also be cleaned using froth flotation. This is a chemical/physical process where the coal adheres to air bubbles in a reagent and floats to the top of the washing device while the refuse sinks to the bottom.

Over 700 coal preparation plants are operating in the United States, almost all of them in the East. They vary widely in level of cleaning done and range in capacities from 200 tons to 30,000 tons per day. Most of the preparation plants are located at or near the mine sites. The others are centrally located to service a specific group of mines. In the bituminous coal region, the plants are sometimes called "tipples" because in the past the coal cars were "tippled" or dumped into the top 


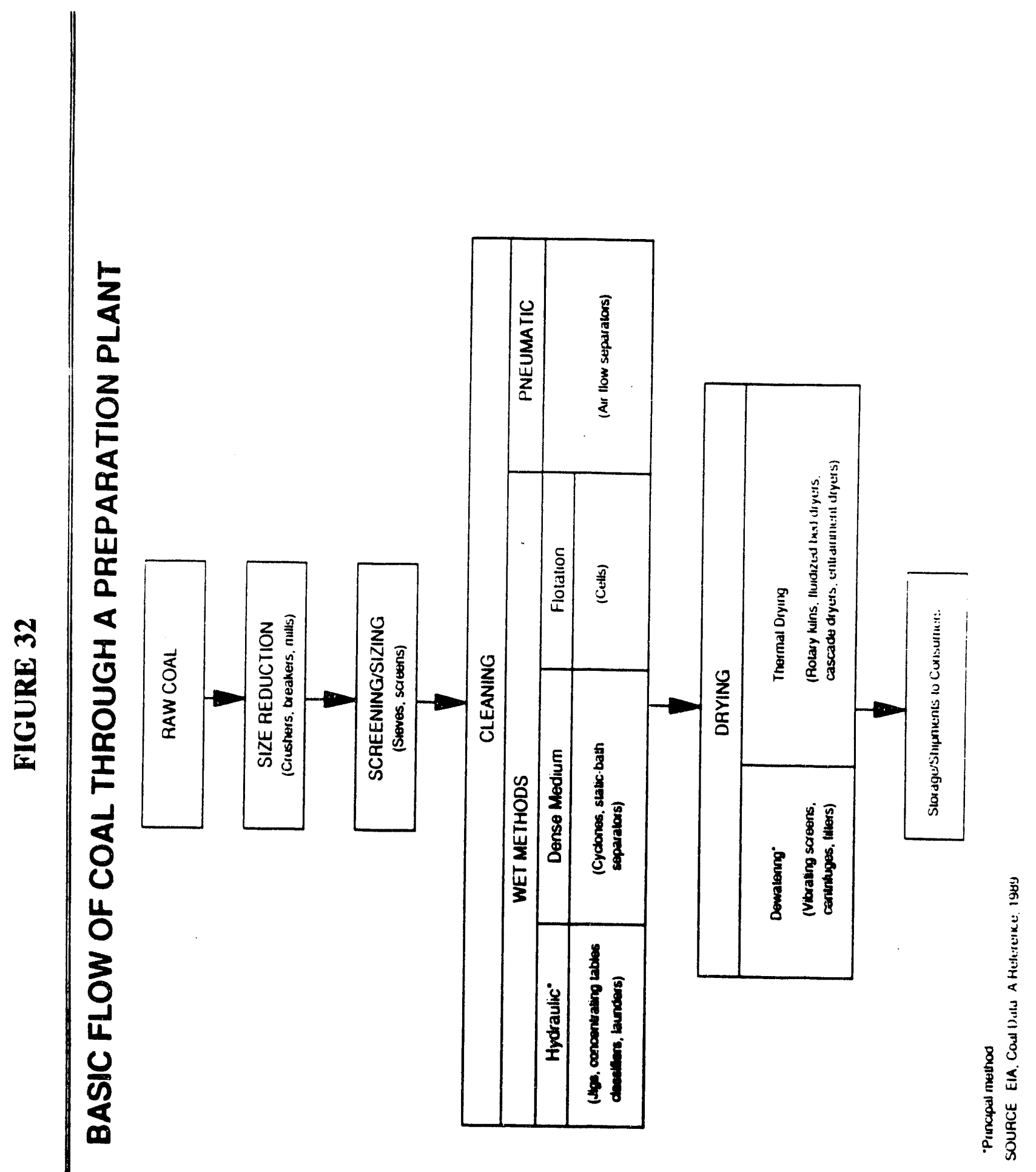

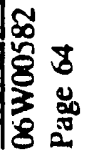


of the plant. Today, this is accomplished by conveyor systems. In the anthracite region of Pennsylvania, preparation plants are often called "breakers", referring to the breaking and sizing that anthracite undergoes at the plant.

\section{IV.C TRANSPORTATION}

Coal is distributed by a transportation network composed principally of railroads, along with barges and Great Lake carriers, trucks, tramways, conveyors, and slurry pipelines. The majority of coal movements have traditionally been by rail. Other transport modes, trucks and barges in particular, are often dependent upon the mine's and consuiner's locations to be viable. Trucks are not well-suited for long-distance transport of coal. while barges are dependent upon navigable waterways. Where the producer and/or consumer locations permit, these two transport modes can be highly competitive industries, both internal $(\omega)$ that mode and with competing transport modes.

More than half of railroad coal shipments are made by unit train. The concept became popular during the 1970s with the need by utilities to economically transport large tonnages of conil between their suppliers and plants. Lnit trains use dedicated equipment, which is often owned by the shipper rather than the railroad, and typically carry about 10,000 tons of coal per shipment. They usually contain 4 locomotives and 100 or more cars and carry coal from a specific source 10 a specilic customer on a predetermined schedule.

Inland water transport of coal is accoinplished by river barging or Great Lakes shipping. Barges are moved by towboats which can handle up to 15 or 20 barges, fewer on smaller rivers. Each barge can hold from 1,000 to about 1,500 tons of coal.

Bulk carrier ships are used to transport coal on the Great Lakes. They are about 700 ) teet long and 70 feet wide and hold about 20,000 tons of coal. Newer ships are about 1,000 feet long and have about three times more capacity.

Trucks are used for short hauls and in some areas, especially in the mountainous regions such as the Appalachians, are the only economical way to ship coal. Individual coal shipments are relatively small with each truck able to hold about 20 to 25 tons, the maximum load allowable on highways.

Aerial tramways, conveyors, and slurry pipelines have seen limited use in transporting coal. Aerial tramways and conveyors are used to link dedicated coal mines with power plants. Only one slurry pipeline is in operation in the U.S. The Black Mesa coal slurry pipeline carries about 4 million tons of coal annually in a slurry of half finely ground coal and half water from the mine in Arizona to the Mohave power plant in southern Nevada. The journey takes four days through an 18-inch pipeline, spanning 273 miles.

\section{IV.D UTILIZATION}

Three end-use applications (both domestically and internationally) account for nearly all U.S. coal consumption: steam production to drive electricity-generating turbines, steam production for industrial uses, and as a feedstock for making coke used primarily by the steel making industry. 
The most common use for coal is to produce high-pressure steam to drive turbines used in the generation of electricity. The coal is burned in boilers, the most commonly used type firing pulverized coal. Snaller amounts are used in cyclone furnaces, which burn crushed coal carried in a whirling stream ol air and in stoker furnaces, which are supplied with crushed coal on a moving grate. A more recent technology is fluidized-bed combustion, a technique for burning crushed coal in a bed that behaves like a boiling tluid as currents of high-velocity air flow through it.

Coal is also used as a source of heat or steam in the manufacture of chemicals, cement. stone. clay. glass. and paper and in the processing of food. Industrial boilers are generally smaller than those used to generate electricity. Industrial boilers often use stokers but ones burning pulverized coal are used in cases where greater amounts of heat and energy are needed. Coal-fired kilns are commonly used in the production of cement and lime.

Another major use of coal is to make coke for the iron and steel industry. Coke is produced by heating a selected blend of high quality bituminous coals in an oxygen-free coke oven until most of the volatiles are driven off. leaving an almost pure carbon product. Coke is used chietly to smelt iron ore in blast turnaces. acting hoth as a source of heat and as physical support for the iron ore and limestone. About 1.100 pounds of coke are consumed for every ton of pig iron produced. $\underline{1} i$

Foundries also use coke as a source of heat to produce iron castings. Other industrial uses of coke include the smelting of phosphate rock.

The coke making process yields other by-products, including benzene, coal tars, naphtha, and similar chemicals. In fact, originally, coke was considered a waste product and the by-products were the primary products of what is now termed the coking process. Many of these chemicals are now primaricy produced from petroleum. They are used to manufacture solvents, varnishes, perfumes, medicines, dyes, and plastics.

Small quantities of coal are also used in a number of applications:

- to produce steam for generating electricity and for heat in some cogeneration plants;

- to f-oduce pipeline-quality gas; since December 1984, lignite has been succes-fully converted at the Great Plains Coal Gasification Plant, near Beuiah, North Dakota;

- to manufacture products such as calcium carbide, silicon carbide, refractory bricks, carbon ' ad graphite electrodes, adsorbents, carbon black, and fillers;

- to manufacture acetic anhydride which is used in making photographic film, acetate yarns and other plastic-based materials; and

- for extraction of montan wax for use in polishes, waxes, carbon paper, phonograph records, inks, coatings, and electrical insulating materials 
Furthermore, resin recovered from coal is used in making adhesives, rubber, varnish, enamel, paint, coating thermoplastics, and ink. Oxidized lignite, or leonardite, is used in oil-drilling muds, in water treatment, and in certain wood stains.

\section{IV.E EMISSIONS AND DISPOSAL OF RESIDUALS}

The Clean Air Act of 1970 and its amendments directed EPA to set limits on the amount of emissions allowable from coal fired power plants and industrial boilers. Solid waste disposal is regulated by the Resource Conservation and Recovery Act of 1976. The impact of mining and coal preparation on water quality was addressed in the Federal Water Pollution Control Act of 1972, later incorporated into the Clean Water Act of 1977 and its amendments.

In issuing regulations pursuant to the Clean Air Act. EPA established allowable emission levels for air pollutants. Of these, limits for sulfur dioxide, nitrogen oxides, and particulates especially applied to the burning of coal. These were later made more stringent for electric utilities in 1978 and for industrial boilers in 1986. Sulfur dioxide is produced from the conversion of the sulfur found in the coal. Nitrogen oxides are created from the nitrogen in the coal and the air used in combustion. The particulates, composed mainly of silica and alumina, are essentially the very fine ash produced during combustion.

Sulfur dioxide emissions are usually controlled by the burning of low sulfur coal, or by "flue gas desulfurization" systems, commonly called "scrubbers". "Wet scrubbers" spray the flue gas with a mixture of water and lime or limestone, which combine with the sulfur dioxide to form a sludge. With the less common "dry scrubbers", a similar spray produces a dry residue.

Nitrogen oxide emissions are usually controlled by reducing the amount of air used during combustion and by lowering combustion temperatures.

Particulates are removed from flue gas by mechanical devices. The most efficient devices are electrostatic precipitators and baghouses. Electrostatic precipitators electrically charge the particulates and collect them on metal plates. Baghouses use fans to draw the flue gases through an array of fabric filters that traps the particulates.

Solid wastes from mining, coal preparation, and power plants are usually disposed of in on-site or near-site landfills or sediment ponds. The manner in which these wastes are treated is governed by the Resource Conservation and Recovery Act of 1976 which ensures that drainage and surface run-off from the wastes do not create environmental problems. Drainage from the solid wastes are minimized through the location of the disposal sites, the design of drainage patterns, and, when necessary, the use of impermeable linings to protect against leakage.

The impact of mining and coal preparation on water quality is addressed in the Clean Water Act. One of the environmental consequences of coal mining can be acid mine drainage, created when sulfuric acid is produced from the reaction of pyrite and other iron sulfides with air and water. This acid drainage increases the solubility of toxic heavy metals and can cause the groundwater to become unfit for use. The Clean Water Act regulates wastes that are discharged into receiving waters. How acid and other toxic drainage is handled at the mine site or preparation plant is outlined in the Surface Mining Control and Reclamation Act of 1977 (SMCRA). SMCRA sets performance standards for maintaining water quality, including design and management standards such as stabilization and control of runoff, disposal of acid and toxic minerals, and maintenance of water 


\section{DEVELOPING TECHNOLOGIES}

Emerging technologies in the mining industries are primarily along the lines of increased mechanization, which, in the process, increases productivity and miner safety. Transportation technologies are creating lighter, larger-volume cars, and more efficient movements between suppliers and customers. Technological developments in coal utilization are directed towards making coal a cleaner burning fuel and a source of more varied products and chemicals.

\section{V.A MINING TECHNOLOGY}

The U.S. Bureau of Mines (BOM) has been directing research to develop technologies for improving the efficiency and productivity of mining operations. These technologies are also aimed at improving the health and safety of mine workers.

The BOM's Automation in Mining Research Program is presently pursuing systems and technologies which would enable the relocation of human workers to more protected and healthier work environments. $15 /$ Computer-assisted machines to perform the most hazardous tasks will probably be introduced in the next 10 to 20 years. Guidance technology and intelligent control systems are being developed that will navigate autonomous mining vehicles. A computer-assisted continuous mining machine is presently being tested by the U.S. Bureau of Mines in an underground Pennsylvania coal mine. The machine is navigated and guided by sensors on its moving appendages. Movement of the machine is controlled by computer and the progress of the machine can be monitored via an externally located television screen.

Expert systems are also being developed to diagnose mechanical problems as they develop and should significantly reduce mining machine downtime caused by electrical, mechanical, or hydraulic failure. These systems monitor hydraulic and electrical systems and provide diagnoses of failures.

New techniques and intelligent signal processing are being investigated to refine and improve coal interface detection. Presently under development is a coal interface detection system. The $\mathrm{BOM}$ is developing this system to locate the coal seam boundary relative to the mining machine, whether it is an automated machine or manually operated. The advantages of the detection system would be improved productivity resulting from greater coal seam recovery, reduced dilution from rock and floor material, and increased cutting rates.

Synthetic doppler radar is being evaluated for its potential for detecting and measuring coal strata. Another possible use is in the detection of coal-air interfaces. This method could help significantly in improving machine guidance systems.

15j Fisher, Thomas, "Harnessing High Technology for Miner Safety, Productivity", Landmarc, p. 14-15, July/August 1989. 


\section{V.B COAL TRANSPORTATION}

Emerging technologies are helping to increase the efficiency of all the rajor transportation modes (railroads, trucks, and barges). The most significant development is the contin ing automation of the industries, particularly in the area of communication and dispatching. Installation of these new systems, especially computer-driven monitoring systems for rail traffic and satellite communications in the trucking industry, has increased worker productivity.

In addition, rail technology is seeing more improvements in locomotive fuel efficiency, electrification of high density tracks, and automated train control systems. Increased rail productivity has also resulted in part, from penetration by recent advances such as larger, lighter (aluminum) hopper cars, concrete ties, welded tracks, and rail lubrication.

\section{V.C COAL LTILIZATION}

Emerging technologies for coal utilization are aimed at clean and efficient power generätion. improving coal combustion, and investigating new uses for coal. Efforts are underway to investigate more effective pre-combustion coal cleaning processes, more efficient and cleaner combustion. and better systems for removing pollutants. In addition. alternative uses for coal such as gasification, liquefaction, coal-oil or coal-water mixtures, and manufacture of organic chemicals are being examined.

The potential market for these technologies is being created by a number of factors: $\underline{16}$

- the continuing concern over the quantity of foreign oil being imported to accommodate the U.S. demand for energy;

- the projected increase in electricity generating capacity that will be required in the next decade; and

- the expected requirement for technologies that permit the use of coal under existing and potentially tighter environmental standards.

The U.S. Department of Energy's Coal Research, Development, and Demonstration Program (RD\&D) strives to make major advances in coal technology and respond to the goals of energy security, a clean environment, and U.S. international competitiveness.

The program scope encompasses each stage of the fuel cycle: pre-combustion, combustion, and conversion. It also addresses the full $R \& D$ spectrum, from applied research to goal-oriented, process or system development (R\&D) and system demonstration (through the Clean Coal Technology Demonstration Program). The program strives to strike an appropriate balance between short-, mid-, and long-term goals and needs. Promising systems emerging from the R\&D program become candidates for large-scale demonstration under the Clean Coal Technology Demonstration Program. These systems also address environmental issues such as solid waste disposal by improving the solid waste's characteristics, making them regenerable (so that none is produced), or transforming them into useable by-products.

16f Welch, Thomas, "Status of Clean Coal Technology", Coal Distribution, Jan.-June 1989. 
In 1984, the DOE Coal Technology Demonstration Program launched a multi-billion dollar series of cost-shared demonstration projects. The program will take some more promising advanced coal-based processing, electric power generation, and emissions control technologies emerging from $R \& D$ and, over the next decade, try to move them towards the commercial marketplace through demonstration. These demonstrations are at a scale large enough to generate the type of data (from design, construction, and operation) necessary for the private sector to judge their commercial potential and to make informed commercial decisions. Table 12 presents the status of the major technologies included in the program.

The Clean Coal Technology Demonstration Program has completed three competitive solicitations during which 46 projects were selected for potential funding. In Phase One, begun in 1984. pruposals were considered that used any type of coal to produce products tor any sector of the energy market. Seventeen projects were selected during this round. Of these, seven have reached cooperative agreements; three are now operational and three are under construction.

Round Two completed solicitation of proposals in 1986. This phase focused on emerging technologies capable of retrotitting, repowering, or modernizing existing facilities. The proposed projects were concentrated in the higher sulfur coal-producing and consuming states of the East and Midwest. Sixteen projects were selected in September, 1988. Of these, cooperative agreements have been signed for nine, one has been withdrawn and negotiations are in progress on the remaining six projects.

Round Three selections were made in December of 1989. The objective of this round was to select projects which would demonstrate technologies capable of being commercialized in the 1990s. Thirteen projects were selected in this round.

Between 1986 and 1992, the Federal government, State governments and private sponsors are likely to invest more than $\$ 6$ billion on projects covering the complete fuel cycle from coal preparation and consumption to the management of wastes produced from coal use. The programs have a dual goal of improving the environmental and economic aspects of utilizing coal, and of achieving energy security through the use coal.

Clean coal technologies can generally be grouped into three categories: new and repowering technologies, retrofit technologies, and conversion technologies. New and repowering technologies replace a significant portion of the original plant and generally increase capacity while reducing emissions. Repowering options invilude advanced combustion and gasification. Repowering provides an attractive option for partially meeting electricity demand growth. The power plant would recover lost capacity, extend its operating life, improve productivity, and concurrently reduce emissions, all at a potentially lower capital cost and electricity cost than conventional generation options.

Among the more promising of these technologies is fluidized-bed combustion. This technology burns crushed coal in a hot turbulent bed of limestone or similar material. Much of the sulfur dioxide produced is absorbed by the limestone, and only small amounts of nitrogen oxides are produced because of the relatively low combustion temperatures. 

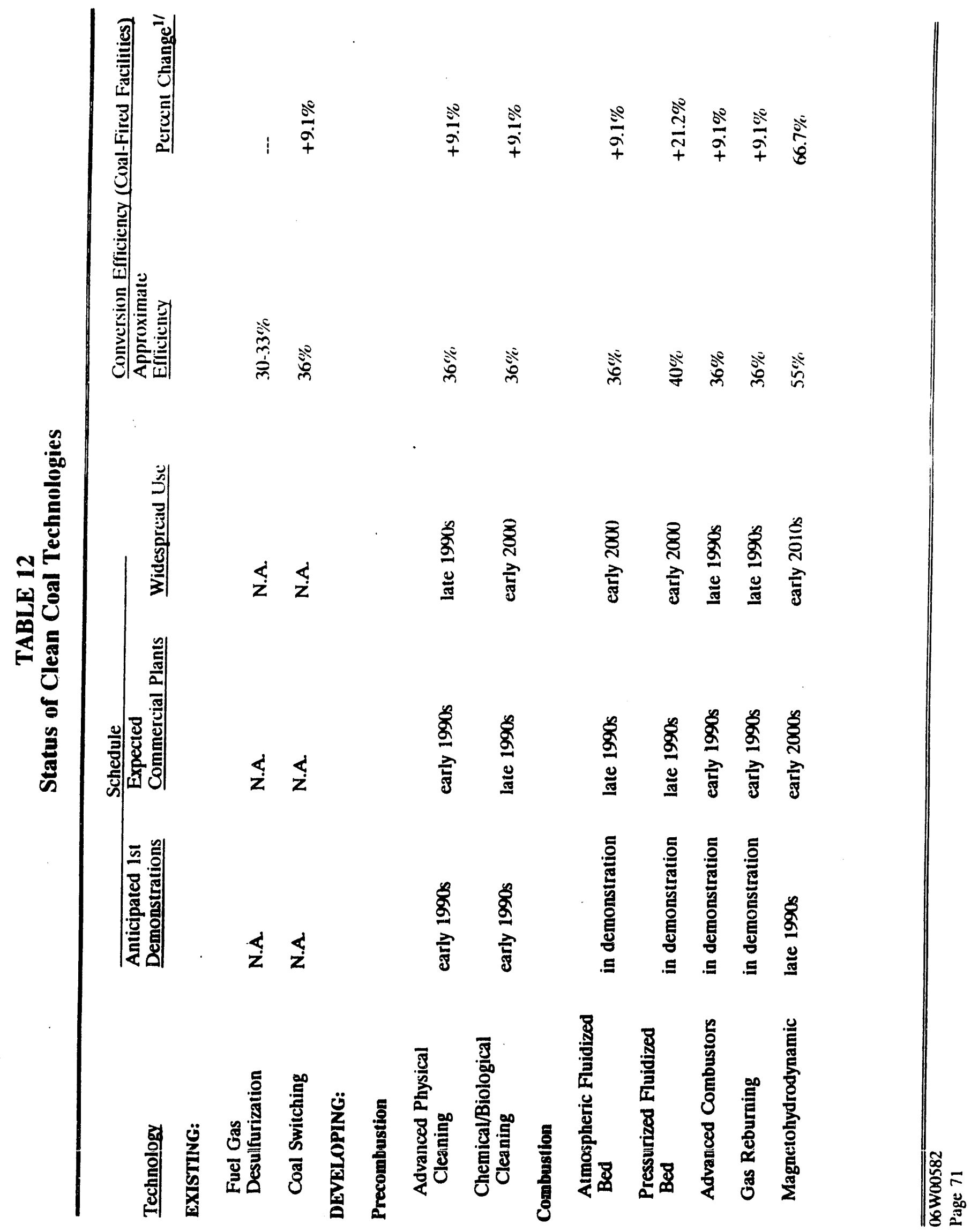


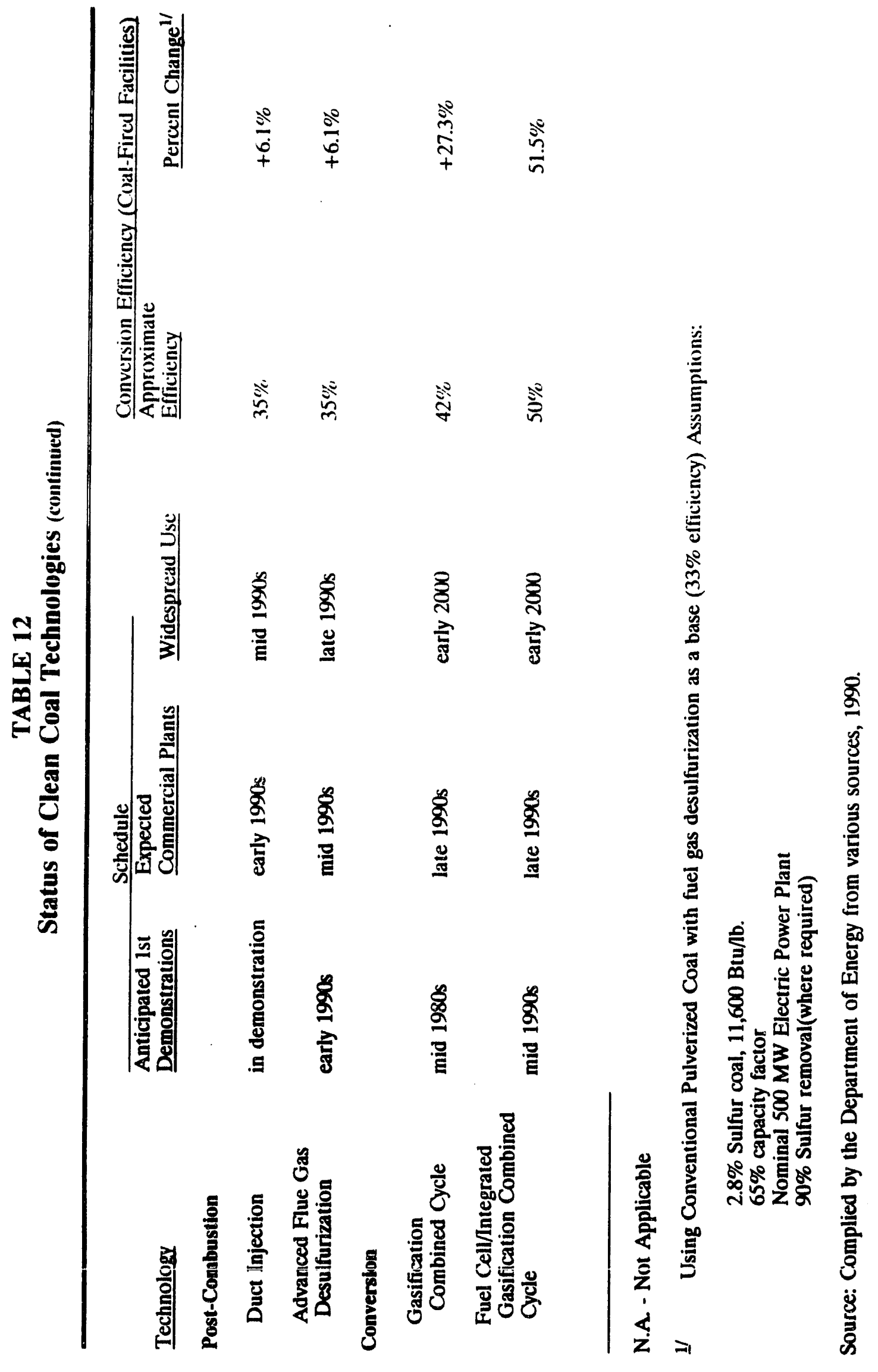


Atmospheric fluidized-bed combustion already shows great potential with over 1,000 megawatts of existing coal-fired generating capacity already being converted to this technology. These include the Tennessee Valley Authority's Shawnee plant in Kentucky, Northern States Power Company's Black Dog plant in Minnesota, and the Colorado-Ute Electric Association's Nuclear plant in Colorado. Pressurized fluidized-bed combustion. uses similar principles but the combustion occurs at elevated pressures of 6 to 16 times atmospheric pressures. This technology is presently being developed and tested in Europe.

Other new and repowering technologies include integrated gasification combined cycle, fuel cells integrated with gasification combined cycle, and magnetohydrodynamic systems. The integrated gasification combined cycle system converts the coal to a combustible gas which is cleaned and then used to power a gas turbine and steam turbine combination. This system configuration can also be implemented with fuel cells instead of a gas turbine to achieve high conversion efficiencies. The magnetohydrodynamic system burns the coal at high temperatures and the combustion gases are used as a conductor in a magnetic field to produce electricity.

Retrofit technologies include pre-combustion coal cleaning and sulfur dioxide and nitrogen oxide emissions control. Advances in coal preparation could enable as much as 90 percent sulfur and ash removal. This can be accomplished by using sophisticated physical. chemical. and biological methods to clean finely ground coal. Advanced physical techniques involve "true heavy media" cyclones, froth flotation, and selective coalescence. Chemical cleaning exposes the coal to molten chemicals which break the bonds of the organic sulfur and enable its removal. Biological cleaning involves using microbes to degrade the sulfur into a removable form:

Emissions control include advanced flue gas desulfurization (scrubbers), sorbent injection, low $\mathrm{NO}_{\mathrm{x}}$ combustion, post-combustion $\mathrm{NO}_{\mathrm{x}}$ control, and combined $\mathrm{SO}_{2}$ and $\mathrm{NO}_{\mathrm{x}}$ control. Conventional flue gas scrubbing technologies are designed to remove 90 percent or more of the $\mathrm{SO}_{2}$ in power plant flue gases. "Wet" scrubbers spray an aqueous mixture of lime or limestone which combines with and removes the $\mathrm{SO}_{2}$ from flue gases. The newer "dry" scrubbers accomplish the same except they spray smaller droplets which evaporate rapidly leaving a dry residue. Advanced flue gas cleanup uses chemicals or electron beam irradiation to improve the effectiveness of $\mathrm{SO}_{2}$ capture.

Impending environmental legislation could potentially require the installation of more expensive coal or environmental control equipment. The size of the retrofit utility market would depend on how stringent the controls are, the phase-in period, and the degree of flexibility utilities will have in meeting the emissions standards. The option of more cost-effective retrofit clean coal technologies would help preserve existing coal markets, especially in Appalachia and the Midwest, and buffer the potential rise of low sulfur coal prices.

Coal gasification and liquefaction conversion technologies have the capability to produce fuels from coal for use in the industrial, commercial, residential, and transportation sectors. All of these sectors have shown declines or little growth in conventional coal use. Coal gasification converts coal into a gaseous product by heating it with steam and oxygen or air. The gas produced can be either cleaned and used as a fuel or processed further to produce synthetic gas. Synthetic gas can be converted to substitute-natural gas, chemicals, or liquid fuels. 
The Nation's first commercial scale synfuel plant began operations in 1984 . This plant, the Great Plains Coal Gasification Plant, near Beulah, North Dakota was developed as a joint effort between DOE and private industries. The plant was sold to the Dakota Gasification Company in November 1988. It converts lignite into an average of 150 million cubic feet of synthetic gas, 93 million tons of ammonia, and 85 tons of sulfur per day.

Coal liquefaction converts coal into liquid fuels using indirect, direct, or mild gasification techniques. In the indirect process, the coal is first gasified and then converted into liquids. In the direct technique. finely ground coal in a solvent is mixed with hydrogen and heated to a high temperature under high pressure. Coal liquids are produced which are then turned into higher quality fuels. In mild gasification or pyrolysis, dry coal is heated in a chemically reducing atmosphere. A heavy synthetic crude oil is produced which can then be refined. In addition, a solid residue, or char. is produced which can also be used as a fuel or in other applications.

Other technologies associated with coal include underground coal gasification, coal-oil and coal-water mixtures, and formcoke. While some of these technologies do not produce coal as an endproduct, they all involve innovative uses of coal. Solvent refined coal technology produces a fuel lower in ash and sulfur then the raw coal feed by dissolving pulverized coal in a solvent to produce a liquid or a solid fuel, depending on the process used.

Underground coal gasification involves the production of combustible gases by igniting and burning the coal underground. The gases are collected at the surface and used as fuel or as feedstock for producing chemicals such as ammonia and urea.

Coalbed methane is produced from gassy seams either by itself or in association with, or prior to, coal mining. However, most methane in existing mining operations are vented. Methane, the chief component of natural gas, can be produced from unmined beds or in advance of mining. The degasification not only supplies a useful product but also increases mine safety by reducing the amount of methane released into the working areas (methane is a common cause of mine explosions).

Coal-oil and coal-water mixtures can be substituted for fuel oil in oil-burning facilities. They have the advantage of being transported, stored, and burned in a manner similar to oil. The technology for producing coal-liquid mixtures has broadened to include methanol and solvent-refined coal.

Formcoke has potential importance as a blast furnace fuel. It is made by heating pellets or briquettes of low-rank coal that are normally unsuitable for conversion into coke. The formcoke could be used in a promising "cokeless" iron-making process that substitutes it for coke to smelt iron ore. The process has potential for reducing the environmental problems associated with coke-making.

As research creates a better understanding of the atomic and molecular structure, composition, and characteristics of coal, it could eventually become a more significant raw material in the manufacturing of a variety of organic chemicals. Many of these chemicals, made today using petroleum, were originally derived from coal during the coking process. In fact, some inroads have been made towards using coal. The Tennessee Eastman Chemicals from Coal plant converts bituminous coal into a number of chemicals. 


\section{V.D TRADE AND INTERNATIONAL COMPETITIVENESS}

International markets offer commercial opportunities for emerging coal technologies being developed and demonstrated in the United States. These new technologies may also be a factor in keeping or expanding the U.S. share of world export coal markets as more stringent environmental regulations are introduced in the international community.

The U.S. was once the dominant supplier of coal technology. However, U.S. developers and manufacturers are increasingly faced with overseas competition. For example, Japan and West Germany have developed wet scrubber technologies comparable to those of the U.S. These two countries could potentially become the principal suppliers of this technology in the 1990s in both the U.S. and the rest of the world. .17

Japan has also become the world leader in developing combustion and post-combustion $\mathrm{NO}_{\mathrm{x}}$ control technology. $\mathrm{NO}_{\mathrm{x}}$ control technology is increasingly being supplied by or licensed from Japan.

The majority of tluidized-bed combustion technologies are presently either supplied or licensed by European sources. Although the U.S. continues to be an important participant in the development of atmospheric tluidized-bed combustion systems, most systems being installed or operated by U.S. industries and utilities are European. Pressurized fluidized-bed combustion development is being led by Europe, which is the only commercial source of this technology.

The best known coal liquefaction facilities are operated in South Africa by South African Coal, Oil and Gas Corporation, Ltd. A range of liquid fuels including gasoline, diesel oil, and jet fuel are produced using the indirect coal liquefaction process.

17) Welch, Thomas, "Status of Clean Coal Technology", Coal Distribution, Jan.-June 1989. 


\section{REGULATORY REGIME: LEGISLATION AND TAXES}

Numerous regulations and taxes affect coal producers, transporters, and consumers. Coal mining is regulated in the leasing of coal reserves, the health and safety of the mines and the environmental impact of the mining on the land, water and air. All these have resulted in the application of fees. taxes, and other levies to ensure the funding needed to carry out the manciates set forth in the legislation. Transportation rates are, for the most part, deregulated; however. occupational and safety regulations still apply for all modes of transportation. Environmental regulation of coal use falls primarily in environmental standards regarding the emission of gasses and particulates, and the disposal of liquid and solid wastes.

\section{VI.A COAL MINING}

The coal mining industry is regulated and taxed in several areas by a combination of Federal and State mandates. The major legislative actions include the Surface Mining Control and Reclamation Act. the Mine Safety and Health Act, and the Federal Coal Leasing Amendments Act.

\section{VI.A.1 Surface Mining and Reclamation Act of 1977}

The Surface Mining Control and Reclamation Act (SMCRA) was passed in 1977. SMCRA was intended to prevent adverse environmental impacts by mandating a mine permitting program for surface mining operations and the surface portions of underground operations. Before the issuance of a mining permit, mining operators are required to demonstrate that the land can be restored to at least its premining use if not better. Each application must contain a detailed mining and reclamation plan. Sufficient data must be provided for the regulatory agency to determine the probable cumulative affects on the land, on hydrology and water availability, and on the air.

SMCRA also requires underground mine operators to take measures to control land subsidence, seal all openings to the surface and prevent acid or other toxic runoff. Subsidence can occur during mining operations and years later when the pillars that were left in the abandoned mine to support the overlying strata finally collapse. Roads, water and gas lines, buildings, and the water table can be severely affected.

Mine permitting is administered at either the State or Federal level. Each coal mining state has the option to maintain its own Office of Surface Mining or choose to have a direct Federal program. State programs must be approved by the Secretary of Interior. If problems arise in state administered programs, the Federal Office of Surface Management can step in temporarily. The Federal government's oversight role is clearly defined as dealing with the breakdown of state programs and not a duplication of state inspection and enforcement.

After a mining application has been approved, the operator must file a reclamation bond sufficient enough for the regulatory agency to complete the reclamation if necessary. Federal regulations on reclamation bond require a minimum of $\$ 10,000$ per permit area, as well as provisions for the operator to carry liability insurance for bodily injury and property damage of $\$ 300,000$ per occurrence and $\$ 500,000$ aggregate. 
An additional charge levied as a result of SMCRA is the abandoned mine reclamation fee. The fee is presently set at $\$ 0.35$ per ton for surface mined coal and $\$ 0.15$ per ton for underground coal, or 10 percent of the value of the coal whichever is less. For lignite the fee is $\$ 0.10$ per ton or 2 percent of the value of the coal, whichever is less. Proceeds trom the fee go into the Abandoned Mine Reclamation fund. The fund is administered by the Secretary of the Interior and is used primarily for the reclamation of land and water resources adversely affected by past mining activities.

SMCRA requires all mining operations to meet the applicable environmental standards regarding emissions, water quality, and disposal of solid wastes. In addition, SMCRA contains specific guidelines for mine-site treatment of these wastes and emissions.

Coal mining, storage, and preparation produce some level of atmospheric emissions (mostly fugitive dust). However, the impacts of these emissions are normally localized and can generally be controlled by proper management such as wetting of waste piles.

Water quality is an important issue associated with coal mining activities. When exposed to air and water, pyrite (sulfide impurities) in coal or coal-derived wastes can oxidize to form sulfuric acid. The resulting lower alkalinity increases the solubility of compounds containing toxic heary metals such as arsenic. cadmium. chromium, lead. mercury, and nickel. Acidity and heavy metals can be harmful to aquatic life and can render water unfit for human use. For surface mining, sediment laden runoff is another important issue, particularly in hilly areas with high rainfall that make erosion control difficult.

In the case of water, the Clean Water Act directed EPA to set effluent limits for mine and preparation plant discharges of iron and total suspended solids from acidic and alkaline mine drainages, manganese from alkaline drainage, and $\mathrm{Ph}$ limits. However, performance standards designed to prevent toxic drainage, run-off containing suspended solids, and disruptions of local water supply resulted from SMCRA and fall under the jurisdiction of the Office of Surface Mining (OSM), U.S. Department of the Interior.

Surface mines, under SMCRA, are required to stabilize disturbed areas, design surface drainage including passage of all surface drainage through at least one sedimentation pond, selectively place and seal acid and toxin forming minerals, achieve rapid revegetation, and, where necessary, maintain a water treatment facilities. In addition SMCRA directs that underground mines are managed to prevent gravity drainage of acid waters and to seal and control subsidence.

Large volumes of waste are produced during the mining and coal preparation. These wastes may constitute $20-30 \%$ of the material removed from the mine; over 3 billion tons of waste have accumulated at more than 4,000 sites to date. Solid waste disposal is regulated in part by the Resource Conservation and Recovery Act which sets limits on the dumping of solid wastes in order to prevent leaching into ground and surface waters. How the solid wastes are handled at the mine or preparation plant fall under the standards set by SMCRA.

SMCRA contains provisions for how coal processing wastes and overburden spoil not required in reclamation are to be handled at the mine site. The waste disposal site must be designed, constructed, and maintained in such a way as to prevent combustion, adverse water quality, and erosion. Mandated provisions include grading and compaction, covering of the waste with at least 4 feet of nontoxic material, and prevention of their use in dams and embankments unless appropriate engineering analyses demonstrate their stability. 
Degradation of surface water and groundwater quality via leaching and erosion is the primary environmental concern related to the disposal of solid wastes. Both SMCRA and RCRA contain provisions aimed at maintaining water quality during waste disposal; however the actual limitations for discharge of chemical and physical effluents fall under regulations promulgated as a result of the Clean Water Act of 1977.

In addition to its potential impacts on water quality, coal mining and preparation affect landuse. Surface disruption, erosion, and landslides resulting from surface mining and subsidence from underground mining are the principal deleterious effects of concern. In addition. noise and visual and hydrological impacts beyond mine boundaries can affect wildlife habitat and recreational activities in a larger area.

\section{VI.A.2 Mine Safety and Health Act}

The Federal Coal Mine Health and Safety Act of 1969 and the updated 1977 version were passed to protect worker health and safety. The 1969 Act established interim mandatory health and safety standards and directed the Department of Interior and Department of Health, Education and Welfare to develop perm it standards. supervise their enforcement, assist the States in setting up health and safety programis. and provide benefits to victims of black lung disease.

The Black Lung Disability Trust Fund was established in 1978, as a result of the Federal Black Lung Benefits Act of 1977. The federal government levies a special excise tax to provide for the Fund. Presently the tax is set at $\$ 1.10$ per ton of coal mined underground and $\$ 0.55$ per ton for surface, or 4.4 percent of the price sold by the producer, whichever is less. The fund is used to compensate miners for total permanent disability caused by pneumoconiosis (black lung) or other industrial respiratory diseases caused by the inhalation of coal and rock dust.

The 1977 Mine Safety and Health Act expanded the 1969 Act by transferring administration of the Act from the Department of Interior to the Department of Labor with the establishment of the Mine Safety and Health Administration (MSHA), establishing mandatory health and safety training, providing protection and support for miners who exercise their safety and health rights, and establishing the Mine Safety and Health Review Commission to settle disputes. MSHA has authority to issue rules and regulations to protect miners. Existing regulations aim at maintaining mine safety by requiring proper roof supports and roofbolting to minimize roof falls in underground mines, setting ventilation and rock dusting standards to control methane and coal dust levels in order to reduce the potential for mine explosions, setting standards for use of electrical equipment, ensuring proper cleanup of work areas, and requiring safety education and monitoring.

MSHA rulemaking is a continual process with new rules instituted as technology advances dictate. Several safety issues are presently being investigated by MSHA. These include revamping of mine roof control standards, mine air quality regulation and control, regulations for use of diesel units in underground mines, and revision of underground coal ventilation standards to permit the use of new technology and to clarify ambiguous and unnecessarily restrictive provisions.

\section{VI.A.3 Federal Coal Leasing}

In western coal mining, a major regulatory area is that of leasing Federal land for coal mining. Leasing of coal reserves varies depending on the owner of the reserves. In the East, most of the 
reserves are owned by the company producing the coal or are privately owned. Lease agreements are negotiated privately and the terms are usually confidential.

In the West. the Federal government owns about 60 percent of the coal resources. Trust responsibility for Indian lands and the formulation of logical mining units combining federal, state, and privately owned coal extends the Federal government's influence to another 20 percent of the resource. The majority of the remaining resources are owned by state governments, Indian nations. and land grant railroad companies. Leasing of Federal coal is regulated by the Federal Coal Leasing Amendments Act of 1976 (FCLAA) and is administered by the Department of the Interior. In general, state leasing regulations follow many of the same guidelines and charge the same royalties as the Federal Government.

The terms set up by FCLAA for leasing of Federal lands require leases to be developed within 10 years (or terminate automatically), to be issued for at least their fair market value. to be leased by competitive bidding with 50 percent leased under a deferred bonus bidding system so that small companies could still compete, and to include charges for lease rental, bonus bids, and a minimum rovalty. That rovalty is generally set at 12.5 percent of the mine-mouth value for coal mined using surface methods and 8 percent of the mine-month value of underground coal. Preference Rights leasing was abolished and no person or corporation can hold more than 100.00(0) acres of leases. Provisions to encourage land use and environmental planning such as the creation of "logical mining units" were also included.

A lease supervision program was also set up to monitor: exploration, development, processing, and handlin of the coal to prevent waste or loss of coal or other resources; insurance of maximum economic recovery of the coal; and compliance of diligent development, continued operation, reclamation plans, and other lease terms required by the Mineral Lands Leasing Act of 1920 and its amendments.

Outstanding issues associated with coal leasing involve the calculation of royalty payments, presently set a 12.5 percent of the value for surface mined coal and 8 percent for underground coal reserves, and the diligent development requirement, presently set at 10 years. In January 1987, the Mineral Management Service (MMS) published for comment a set of proposed regulations which would significantly alter' the methodology by which royalties are calculated. In January 1989, the MMS issued final rules which retained the concept of royalties calculated on gross proceeds, but deleted from the definition take-or-pay and certain advanced payments. The valuation standards for ad valorem (added value) leases also allowed for the deduction of abandoned mine fees, black lung fees, and state and local and valorem taxes. The revised regulations also removed limitations on washing and transportation allowances so long as these did not reduce the value of the coal to zero, and contained provisions to avoid assessing a royalty on the enhanced value of coal from new preparation processes.

Legislation has also been introduced to extend the time for diligent development for coal leases beyond the existing term of 10 years. The industry argues that the start-up time for large western surface mines often requires a much longer period and more flexibility should be granted. The legisiation has yet to clear the appropriate Congressional Committees and be brought to the floor for action.

Other than the taxes and charges resulting from regulatory ac. ivity on the coal industry, the Federal Tax Code allows mining companies to deduct all operating and capital costs from revenues 
when the Federal taxable income is determined. Mine operating costs which can be deducted include mining and milling costs, marketing and transportation costs, municipal taxes, private royalties and general administrative costs. Permisible capital cost deductions are interest payments on debts. depreciation on equipment and rea! property, and percentage depletion. Percentage depletion for coal and lignite mines is presently set at 10 percent of gross income from the property. excluding vents and royalties paid or incurred by the taxpayer. The percentage depletion may not exces 50 percent of the taxpayer's income for the property when ccmputed without allowance for depletion.

\section{VI.B TRANSPORTATION}

Regulatory activity in the transportation industry is mostly concerned with worker safety, and environmental protection and routing issues during the construction of new routes. Until 1980, rates were also regulated for the trucking industry and railroads. Safety regulations are outlined in the Department of Labor's OSHA regulations and deal with the length of shifts and job hazards specitic to each industry.

Roads constructed using federal tunds are subject to extensive environmental protection and routing requirements under the Department of Transportation regulations. Rights-of-way over public lands must be permitted by the Federal agency with jurisdiction: Federal right-of-way laws usually limit the width of the path. Dredging for waterways or construction of any structure on navigable waterways must be permitted by the Army Corps of Engineers.

Longhaul trucking rates became completely deregulated in 1980, making railroads the only transportation mode with auy form of rate regulation. However, rail rates also became partially deregulated in 1980 by the passage of the Staggers Rail Act. The Staggers Rail Act allowed more flexibility in rail rate pricing by authorizing railroad contract service, establishing rate-to-variable cost threshoids below which rail rates are not subject to review by the Interstate Commerce Commission (ICC), and inaugurating a quarterly index to adjust rates based on changes in costs. The Staggers Rail Act also required the ICC to review the overall pricing efficiency of a railroad to determine whcther a rate is reasonable and gave it the authority to determine if a railroad dominated the market $\checkmark r$ certain movements, in which case its rates would remain subject to a review of maximum rate reasonableness.

Since the passage of the Staggers Act, addition al legislation has been sought by some shippers to further protect captive shippers by providing rate guidelines and by preventing railroads from refusing to enter efficient and reasonable competitive arrangements. The ICC has also developed a proceeding to include railroad productivity changes in the determination of the quasisty index and is developing a new accounting and costing system in order to provide more accurate cost estimates (the Uniform Rail Costing System). Finally, legislation has been introduced to amend the Clayton Anticrust Act by removing the protection for railroads from antitrust laws and allowing federal district courts to grant injunctive relief to a shipper.

\section{VI.C UTILIZATION}

The potential tor adverse environmenta! impacts from the use of coal was recognized during the $19^{\circ}$ is and addressed under numerous legislative acts. Chief among these were the Clean Air Act of $19 \% 0$, the Clean Waiter Act of 1977 , and the Resource Conservation and Recovery Act of 1976. The main issues of concern were the emission of air pollutants, the discharge of effluents in waste water, and the seepage from solid waste disposal sites. 


\section{VI.C.1 Emissions}

Since electric utilities consume most of the coal used in the United States, utilities account for a large percentage of the coal-related emissions. The principal criteria $\frac{18}{8}$ pollutants emitted from coal combustion are sulfur dioxide $\left(\mathrm{SO}_{2}\right)$, nitrogen oxides $\left(\mathrm{NO}_{\mathrm{x}}\right)$, and particulate matter (PM). Emissions of $\mathrm{SO}_{2}$ and $\mathrm{NO}_{\mathrm{x}}$ are a concern not only because degradation of air quality can affect human health and welfare, but because they are involved in the complex atmospheric reactions that can produce acidic deposition.

The Clean Air Act of 1970 directed the Environmental Protection Agency to set New Source Performance Standards for the allowable emission levels of $\mathrm{SO}_{2}, \mathrm{NO}_{x}$, and particulates for industrial and electric utility coal consumers built as of 1971. Electric power plants and industrial boilers built before 1971 were subject to emission standards set by the States and approved by the EPA. EPA has jurisdiction over compliance with all air pollution regulations.

Coal-burning units that started construction between 1971 and September 1978 were required to limit $\mathrm{SO}_{2}$ emissions to 1.2 pounds per million Btu (lbs. $/ \mathrm{mmBtu}$ ), $\mathrm{NO}_{\mathrm{x}}$ to $0.7 \mathrm{lbs}$. $/ \mathrm{mmBtu}$; and particulates to $0.1 \mathrm{lbs} . / \mathrm{mmBtu}$. As of September. 1978, coal-fired plants constructed or modified by electric utilities were subject to even more stringent levels. The revised New Source Performance Standards were based on the level of uncontrolled emission and were defined in terms of percentage reductions ranging from 70 to $9 \mathrm{~J}$ percent. More than 90 percent reduction from previous levels is requirea if the uncontrolled emissions exceed $12 \mathrm{lbs} . / \mathrm{mmBtu} ; 0$ percent reduction is required if the uncontrolled emissiors are less than $2 \mathrm{lbs}$./mmBtu. Industrial boilers, constructed or modified after June 1986, are also required to meet stringent standards.

Although coal use has increased substantially over the last few decades, emissions of $\mathrm{SO}_{2}$ and PM have declined due to increased application of pollution control devices (e.g., flue-gas desulfurization [FGD] devices, or scrubbers), use of coal with lower sulfur content for $\mathrm{SO}_{2}$ control, and use of eiectrostatic precipitators and fabric filters for PM control. Currently, under New Source Pe formance Standards, all new coal-fired powerplants are required to install both FGD systems with sulfur diuxide removal efficiencies of $70-90 \%$ and very efficient (over $99 \%$ removal) PM controls. In addition, many older plants were required under State Implementation Plans (SIPs) to reduce $\mathrm{SO}_{2}$ and PM emissions in order to comply with ambient air quality standards. However, over the last decade or so, $\mathrm{NO}$ emissions have increased; little control of $\mathrm{NO}_{\mathrm{x}}$ from stationary combustion sources has been required to meet ambient air quality standards. Estimates of annual air pollutant emission from coal combustion for selected years in the period between 1970 and 1987 are shown in Table 13, along with the coal consumption in those years. Emission rates (i.e., emissions per Btu of coal consumed) of all three sriteria pollutants have decreased.

Future decreases in criteria air pollutant emissions would be expected if existing coal-fired combustors (both in the utility and other demand sextors) are replaced or repowered with clean-coal technologies (CCTs). Some new systems, such as integrated gasification combined-cycle (IGCC) technologies, have been demonstrated to control $\mathrm{SO}_{2}$ emissions to much lower levels than conventional coal-fired combustors with FGD. In addition, CCTs such as IGCC and fluidized bed

18 Criteria air pollutants are those for which the U.S. Environmental Protection Agency, under the authority of the Ciean Air Act, has promulgated National Ambient Air Quality Standards to protect human health and welfare. 
combustors have the added benefits of decreasing $\mathrm{NO}_{x}$ emissions and increasing overall energy efficiency (unit of energy output per unit of energy input). Small-scale CCTs with low emission rates are also being developed for use in the residential, commercial, and industrial sectors. Further emissions reductions from current levels could also be achieved through retrofit of controls (such as FGD, low sulfur coal, and low- $\mathrm{NO}_{x}$ burners) on existing uncontrolled electric utility plants. However, this could result in a decrease in energy efficiency, since operation of add-on pollution control equipment requires additional energy to operate.

In addition to existing legislation. two issues are outstanding and are presently being debated. These involve the acid rain issue and growing concerns about global warming. The Senate recently passed S.1630, a compromise version of the Administration's proposed Amendments to the Clean Air Act introduced on June 12,1989. In May, 1990, the House of Representatives voted to approve its version of the bill (H.R. 3030). Final legislation could be signed into Law by this summer and almost certainly during this Congress. The Senate proposal is aimed at three broad problems:

- Acid Rain - By 2000. the plan calls for a 9.5 million ton (10 million by 2010) reduction in $\mathrm{SO}_{2}$ emissions below 1980 levels, and a 2 million ton cut in $\mathrm{NO}_{\mathrm{x}}$ emissions from future levels. The bill establishes some local coal protection by providing incentives in Phase One for the installation of conventional clean coal technology.

- Nonattainment - By 2000 , all cities currently not meeting the health standards of ozone and carbon monoxide will be brought to attainment, most by 1995 .

- Toxic Emissions - Factories and plants emitting toxic compounds must use the best technology currently available in order to achieve a 75 to 90 percent reduction in suspected carcinogenic pollutants.

Another concern related to coal combustion is emission of carbon dioxide $\left(\mathrm{CO}_{2}\right)-$ a "greenhouse gas." Increasing concentration of $\mathrm{CO}_{2}$ in the atmosphere may lead to global warming, although the rate at which such warming would occur and the effect of other factors on climate change are not fully understood. Emissions of $\mathrm{CO}_{2}$ from coal combustion are shown in Table 13. Since coal use has been increasing over the period shown, coal-related $\mathrm{CO}_{2}$ emissions have been on the rise. Since CCTs have somewhat higher efficiencies than conventiona. systems, increased use of CCTs could slow the rate of increase of $\mathrm{CO}_{2}$ emissions from coal combustion.

\section{VI.C.2 Waste Disposal}

The implenentation of air pollution control over the past few decades has resulted in the increased production of byproduct solid or semisolid wastes - fly ash and scrubber sludge — which are typically disposed of on land. Coal combustion, with or without air pollution control, also produces bottom ash. Currently, these three waste streams account for about $90 \%$ of the 80 million tons/year of solid wastes produced by coal-fired utilities. Disposal of these large-volume wastes can involve hundreds of acres for a large facility. Thus, the availability of land and concerns over the appropriate use of the land are often significant issues. 
TABLE 13

Atmospheric Emissions from Coal Combustion

\begin{tabular}{|c|c|c|c|c|c|}
\hline \multirow[b]{2}{*}{ Sector/Year } & \multirow{2}{*}{$\begin{array}{l}\text { Coal } \\
\text { Consumptioit } \\
\text { (quadrillion }\end{array}$} & \multicolumn{4}{|c|}{ Annual Emissions (10 $10^{6}$ tons) } \\
\hline & & $\mathrm{SO}_{2}$ & $\mathrm{NO}_{\mathrm{x}}$ & $P M$ & $\mathrm{CO}:$ \\
\hline \multicolumn{6}{|c|}{ Electric Utilities } \\
\hline 1970 & 7.23 & 16.0 & 3.3 & 2.4 & 181 \\
\hline 1973 & 8.66 & 17.4 & 3.8 & 1.9 & 217 \\
\hline 1975 & 8.79 & 16.9 & 4.0 & 1.6 & 220 \\
\hline 1978 & 10.24 & 16.0 & 4.5 & 1.2 & 256 \\
\hline 1980 & 12.12 & 16.2 & 5.2 & 0.8 & 303 \\
\hline 1985 & 14.54 & 15.4 & 6.2 & 0.4 & 364 \\
\hline 1987 & 15.17 & 15.2 & 6.4 & 0.4 & 379 \\
\hline \multicolumn{6}{|c|}{ Resid/Comm'l/Indus } \\
\hline 1970 & 2.38 & 3.5 & 0.8 & 1.6 & 67 \\
\hline 1973 & 1.75 & 2.4 & 0.6 & 0.7 & 49 \\
\hline 1975 & 1.62 & 2.1 & 0.6 & 0.5 & 45 \\
\hline 1978 & 1.62 & 1.9 & 0.5 & 0.3 & 45 \\
\hline 1980 & 1.49 & 1.7 & 0.5 & 0.3 & 42 \\
\hline 1985 & 1.84 & 2.1 & 0.6 & 0.2 & 49 \\
\hline 1987 & n.a. & 1.9 & 0.6 & 0.1 & n.a. \\
\hline \multicolumn{6}{|c|}{$\begin{array}{l}\text { n.a. }=\text { not available } \\
{ }^{*} \text { Expressed as } 10^{6} \text { tons of cäríton emitted as } \mathrm{CO}_{2} \text {. }\end{array}$} \\
\hline
\end{tabular}

Source: DOE, Office of Envircnmental Policy 
Presently, about $17 \%$ of the fly ash and less than $2 \%$ of the FGD sludge is reused in commercial applications. Of the remainder, roughly two-thirds is transported as wet slurry to nearby ponds; the rest is hauled dry or dewatered and then disposed of in landfills. Fly ash disposal in ponds or landfills may leach solubie alkali metal salts and trace elements into ground and surface waters. To control leaching, pond liners and/or proper site selection and monitoring are used. Leachate from FGD scrubber sludge contains large concentrations of chloride, calcium, and sulfate; if combined with fly ash. the latter adds a substantial load of trace elements to the mixture. Leaching problems can be minimized by physically or chemically treating the sludge to reduce its porosity and permeability. Utility and industrial coal users are increasingly moving to dry disposal in landfills for their large volume wastes. Another trend is towards increased use of bottom liners, leachate collection systems, and groundwater monitoring systems for new landfills. Such measures substantially increase disposal costs.

The storage and disposal of solid wastes are regulated under the Resource Conservation and Recovery Act (RCRA) of 1976. RCRA was enacted to prevent adverse affects on health and the environment due to the disposal of solid wastes. RCRA regulations are primarily aimed at preventing leaching of toxins into groundwater and surface waters.

Water consumption and thermal pollution are additional concerns for coal-fired powerplants. The Clean Water Act limits thermal discharge from electricity generating plants, and provides guidelines for the location, design. construction, and capacity of cooling water intake structures.

Cooling systems of powerplants are the largest water users. The large water consumption by cooling systems reduces the amount of water available for diluting downstream discharges and decreases stream flow, which can be critical during droughts. As a result, conflicts over water rights and quality can develop, especially in the West. 

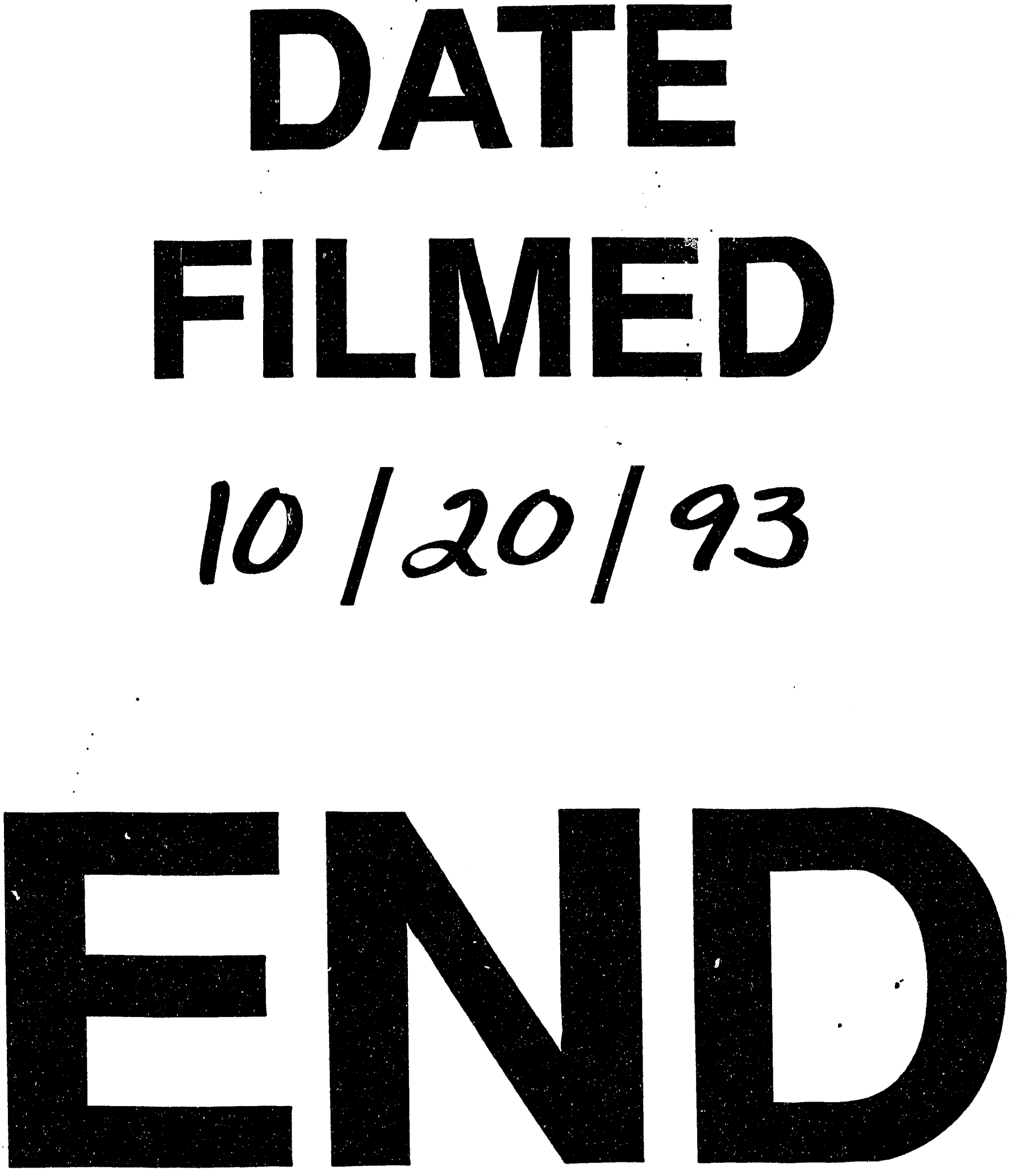
